\title{
Carrera eclesiástica e inquietudes religiosas de un clérigo castellano del siglo xv: Nuño Álvarez de Fuente Encalada, chantre de la Iglesia de Cuenca
}

\author{
The Ecclesiastical Career and Religious Concerns of a Castilian \\ Clergyman in the Fifteenth Century: Nuño Álvarez de Fuente \\ Encalada, Cantor in the Church of Cuenca
}

\author{
Jorge DíAZ IBÁÑEZ \\ Universidad Complutense. Madrid \\ jdiazib@ghis.ucm.es
}

\begin{abstract}
RESUMEN
Análisis, en su contexto histórico, de la figura de Nuño Álvarez de Fuente Encalada, chantre de la iglesia de Cuenca durante más de treinta años, un eclesiástico castellano del siglo XV apenas conocido por la moderna historiografía, pero muy singular por ciertos aspectos de su dilatada biografía. Así, se estudian los orígenes de su carrera eclesiástica, su presencia en el concilio de Basilea, sus años de estudio en Bolonia antes de llegar a Cuenca, sus diversas tareas al servicio de la iglesia conquense, sus inquietudes intelectuales reflejadas en los libros de su biblioteca personal y sobre todo su peculiar espiritualidad, preocupaciones religiosas y actividades caritativas y de mecenazgo que llevó a cabo, motivos por los cuales tras morir comenzaría a ser objeto de recuerdo y veneración en la iglesia conquense.
\end{abstract}

Palabras clave: Cuenca, clero, chantre, biblioteca eclesiástica, religiosidad, caridad, memoria histórica, Castilla, siglo XV, Nuño Álvarez de Fuente Encalada.

\begin{abstract}
The biography, in its historical context, of Nuño Álvarez de Fuente Encalada, cantor in the church of Cuenca during more than thirty years, a Castilian clergyman of the fifteen century barely known to the modern historiography, but very particular due to of some facets of his life and ecclesiastical career. We study the origins of his ecclesiastical career, his involvement in the Council of Basil, his academic education at the University of Bolonia, his services to the church of Cuenca, his intellectual inquisitiveness and personal library, and mainly his peculiar religiosity, activities of charity and patronage, for which he would be remembered and venerated in the church of Cuenca after his death.
\end{abstract}

Key words: Cuenca, Clergy, Cantor, Ecclesiastical Library, Religiosity, Charity, Historical Memory, Castile, $\mathrm{XV}^{\text {th }}$ Century, Nuño Álvarez de Fuente Encalada.

Sumario: 1. Diplomacia y formación académica en los inicios de una carrera eclesiástica. 2. El chantre Nuño Álvarez como servidor y benefactor de la iglesia conquense. 3. La biblioteca del chantre. 4. Religiosidad y ejercicio de la caridad; las acciones de mecenazgo. 5. El testamento y la muerte del chantre. 6. La memoria histórica de Nuño Álvarez. 7. Conclusión. 8. Apéndice documental. 
El 15 de abril de 1631, a las diez de la noche, a puerta cerrada dentro de la catedral de Cuenca, en un acto ceremonial que se asemejaba mucho al que un siglo atrás había tenido lugar ante la tumba de San Julián (1198-1208), segundo prelado de la diócesis, en presencia del obispo Enrique Pimentel y de algunos miembros del cabildo catedralicio, reunidos en la capilla de San Miguel, se procedió a desenterrar los restos de Nuño Álvarez de Fuente Encalada, que en el siglo XV había sido durante más de tres décadas chantre y canónigo de la iglesia conquense, y hacia el que existía una particular veneración. Pocos días después el obispo Enrique Pimentel mandó que en dicha capilla se construyese un nicho decente donde depositar los huesos de Nuño Álvarez, a modo de reliquias, a la vez que se realizaban gestiones ante la Santa Sede para tratar de lograr su beatificación en atención a sus heroycas y excelentes virtudes. Por entonces la memoria histórica local en torno a este personaje ya contaba con una larga trayectoria.

El objeto del presente trabajo no es otro que estudiar en su contexto histórico y en sus diversas facetas la figura de este eclesiástico castellano del siglo $\mathrm{XV}$, apenas conocido por la moderna historiografía pero sin duda muy singular, no porque desempeñase un papel destacado en los grandes círculos de poder político del momento, sino por otros aspectos de su dilatada biografía como fueron sus modestos orígenes sociales, sus labores auxiliares en el concilio de Basilea, sus largos años de estudio en Bolonia antes de llegar a Cuenca, sus diversas tareas al servicio de la iglesia conquense, sus inquietudes intelectuales reflejadas en los libros de su biblioteca personal y sobre todo su peculiar espiritualidad, preocupaciones religiosas y actividades caritativas y de mecenazgo que llevó a cabo, motivos por los cuales tras morir comenzaría a ser objeto de recuerdo y veneración en la iglesia conquense. Sobre todas estas cuestiones hablaré en las páginas siguientes.

\section{DIPLOMACIA Y FORMACIÓN ACADÉMICA EN LOS INICIOS DE UNA CARRERA ECLESIÁSTICA}

Según la mayor parte de sus biógrafos, Nuño Álvarez de Fuente Encalada nació hacia comienzos del siglo XV en esta última localidad, perteneciente a la diócesis de Astorga, y que actualmente se encuentra en la provincia de Zamora. Asimismo, dichos autores insisten en la pertenencia de Nuño Álvarez a la rama del linaje Osorio que acabaría obteniendo el marquesado de Astorga ${ }^{1}$. Dada la onomástica del personaje, que siempre aparece citado en la documentación como Nuño Álvarez de Fuente Encalada o simplemente como Nuño Álvarez, no caben dudas sobre su nacimiento en

${ }^{1}$ PINEDA Y HURTADO DE MENDOZA, J. de, Proles Aegidiana seu catalogus illustrium virorum qui ex sacro et perinsigni Collegio Maiori Sancti Clementis Hispanorum ...huc usque in lucem prodiere, Nápoles, 1632, p. 9. En la misma línea se pronuncia el anónimo autor de la primera biografía del chantre, Vida del Venerable don Nuño Álvarez de Fuente Encalada, chantre e canónigo de la Santa Yglesia cathedral de la noble çibdad de Cuenca, que se conserva en el Archivo Catedralicio de Cuenca (en adelante: ACC), Obras Pías, leg. 315, exp. 3. 
este lugar de la diócesis astoricense, a pesar de que alguno de sus biógrafos sitúe su lugar de origen en Pontevedra ${ }^{2}$.

Muy dudosa es, sin embargo, por no decir que intencionadamente falsa, la supuesta pertenencia al poderoso linaje de los Osorio que le atribuyen todos sus biógrafos. Sí es verdad que durante el siglo XIV se había ido consolidando el control de este linaje sobre la ciudad y tierra de Astorga, hasta que finalmente, en 1465, Enrique IV otorgó a Álvaro Pérez Osorio el señorío sobre la ciudad con el título de marqués de Astorga; veinte años antes, en 1445, el padre del anterior, Pedro Álvarez Osorio, había recibido de Juan II el condado de Trastámara ${ }^{3}$. Pero lo cierto es que en las genealogías de los Osorio para nada aparece nuestro personaje. Tras realizar un análisis crítico de las fuentes, creo que pueden esgrimirse bastantes argumentos en contra de la supuesta pertenencia de Nuño Álvarez al linaje Osorio.

Primeramente, según se ha dicho, en la documentación medieval siempre se le cita como Nuño Álvarez de Fuente Encalada, y así aparece también en su testamento de 1476, en el que no hay ni la más mínima referencia a miembros de linaje de los Osorio. En todo caso podría aventurarse la hipótesis de que quizá su familia, de orígenes más bien modestos, pudo haber estado en algún momento al servicio de los Osorio, cuya influencia se extendía por entonces a gran parte del obispado de Astorga, pero sin que ello signifique que Nuño Álvarez perteneciese a este linaje.

Por otro lado, si hubiese sido así, extrañaría su lento progreso en la carrera eclesiástica dado que, según pronto se verá, cuando Nuño Álvarez aparece por vez primera en las fuentes incorporándose en 1434 al concilio de Basilea, era simplemente beneficiado en la iglesia conquense y titular de pequeños beneficios diocesanos, pero no de una canonjía ni de una dignidad catedralicia, mientras que otros clérigos realmente pertenecientes al poderoso linaje de los Osorio consiguieron bien pronto, gracias a la determinante influencia de su familia, dignidades catedralicias y luego cargos episcopales ${ }^{4}$.

También cabría preguntarse hasta qué punto pudo influir algo en esta confusión en torno a sus orígenes familiares, que acabaría siendo una interesada manipulación, el hecho de que en octubre de 1425 se encontrase estudiando en la universidad de Bolonia, donde también estudiaría Nuño Álvarez, el deán del cabildo catedralicio leonés

2 SILVESTRE DE VELASCO Y HERRERA, S., Compendio de la nobilissima fundación y privilegios del colegio mayor de señor San Clemente de los españoles de Bolonia ... y vidas y gloriosas muertes de Sr. San Pedro de Arbues y venerable Nuño Álvarez Ossorio, dignissimos alumnos, Madrid, 1695, p. 192, quien indica haber tomado de Baltasar Porreño el dato acerca del lugar de nacimiento del chantre Nuño Álvarez.

3 MARTín FUERTES, J. A., "Los Osorio y el marquesado de Astorga”, Tierras de León, 27 (1987), p. 40. Sobre este linaje también puede verse el trabajo de SALAZAR Y ACHA, J. de, "Los Osorio: un linaje de más de mil años al servicio de la Corona", Anales de la Real Academia Matritense de Heráldica y Genealogía, 4 (1996-1997), pp. 143-182.

${ }^{4}$ Para el siglo XV contamos con una cierta representación de miembros del linaje de los Osorio ocupando importantes puestos eclesiásticos. Así, Álvaro Osorio, protegido de don Álvaro de Luna, fue obispo de Lugo (1434-1440) y luego de Astorga (1440-1463). NIETO SORIA, J. M., Iglesia y génesis del Estado moderno en Castilla (1369-1480), Madrid, 1993, p. 452. Otro ejemplo es García Enríquez Osorio, que fue obispo de Oviedo (1441) y arzobispo de Sevilla (1442-1448). EUBEL, C., Hierarchia Catholica Medii Aevi, Münster, 1914, vol. II, pp. 209 y 165. 
Alvar Pérez Osorio ${ }^{5}$, si bien no tenemos constancia de que este último residiese, como Nuño Álvarez, en el colegio de San Clemente ${ }^{6}$.

Por otro lado, si hacemos un rápido repaso a la procedencia social de los colegiales de San Clemente de Bolonia desde la puesta en marcha de la institución en 1368 hasta fines del siglo XV, vemos que durante esta época, de acuerdo con las intenciones del fundador del colegio -el cardenal Gil Álvarez de Albornoz-, la inmensa mayoría de los colegiales, salvo algunas excepciones, son de modestos orígenes sociales y por consiguiente de escasos recursos económicos, ajenos en su mayoría al mundo de la nobleza ${ }^{7}$. De hecho estos colegiales conseguían una plaza en la institución gracias a la necesaria mediación y carta de presentación de algún obispo y cabildo catedralicio cuya diócesis, según los estatutos del colegio, tuviese derecho a presentar candidatos. En este sentido los inicios de la carrera de Nuño Álvarez se desarrollaron bajo el amparo y protección del obispo conquense Álvaro Núñez de Isorna (1418-1445) y de Pedro Arias Bahamonde, deán de Orense y a menudo vicario general del obispado de Cuenca en nombre del obispo Isorna, a quienes Nuño Álvarez consideraría siempre como "sus señores" y benefactores, lo que constituye un elemento más que nos está indicando los probablemente modestos orígenes sociales de nuestro personaje.

Finalmente hay que destacar que el hecho que sin duda fue más determinante para que, tras la muerte de Nuño Álvarez de Fuente Encalada en 1476, sus biógrafos y el clero catedralicio conquense insistiesen en hacerle pertenecer al ilustre linaje de los Osorio, marqueses de Astorga, vino dado por la creciente importancia que, a medida que avanzaba el siglo XVI y mucho más durante la centuria siguiente, se otorgó a la "limpieza de sangre" en los cabildos eclesiásticos seculares de España moderna, así como en el colegio de San Clemente de Bolonia. Debido a ello, y habida cuenta de la particular veneración que ya en el siglo XVI despertaba la figura del chantre Nuño Álvarez en la memoria histórica de la diócesis conquense, resultaba absolutamente necesario garantizar unos ilustres y fuera de toda duda nobilísimos orígenes familiares, para lo cual la solución que se consideró más conveniente fue la vinculación del personaje con el linaje de los Osorio. Cabría incluso preguntarse, a modo de hipótesis, si esto último pudo responder a la necesidad de ocultar un posible nacimiento ilegítimo de Nuño Álvarez o incluso unos supuestos orígenes judeoconversos de su familia, lo que explicaría todavía mejor la reiterada insistencia de sus biógrafos en hacerle pertenecer al linaje de los Osorio. No obstante, se trata de una hipótesis de imposible confirmación, pues hasta la fecha no he podido encontrar ningún tipo de testimonio documental capaz de arrojar alguna luz sobre los ignotos orígenes familiares de nuestro personaje. En el último apartado del presente estudio retomaré el asunto de la manipulación de los orígenes familiares de Nuño Álvarez por parte de sus biógrafos.

${ }^{5}$ RODRÍGUEZ FERNÁNDEZ, J., "En torno a varios becarios de León en el Colegio español de Bolonia", en VERDERA y TUELLS, E. (ed.), El cardenal Albornoz y el Colegio de España, Zaragoza, 1971, vol. II, pp. 359-360.

${ }^{6}$ PÉREZ MARTÍN, A., Proles Aegidiana I. Introducción. Los colegiales desde 1368 a 1500 (colección Studia Albornotiana, vol. 31), Bolonia, 1979, pp. 247-248, nota 250.

${ }^{7}$ En cambio posteriormente, ya en época moderna, el colegio acabaría convirtiéndose en un centro para la nobleza y la burguesía. PÉREZ MARTíN, A., Proles Aegidiana I..., p. 47. 
Según se ha dicho, desde unos modestos orígenes sociales, el progreso de Nuño Álvarez en la carrera eclesiástica se vio favorecido fundamentalmente por la protección que le otorgó en todo momento el obispo conquense Álvaro Núñez de Isorna ${ }^{8}$, de quien era familiar, y a quien Martín V había concedido facultad para conferir beneficios vacantes a favor de sus numerosos familiares y nepotes. Otro personaje a quien Nuño Álvarez también consideró como su señor y protector fue Pedro Arias Bahamonde, deán de Orense y durante largos períodos vicario general de la diócesis conquense en nombre del obispo Isorna, hasta su nombramiento como obispo de Mondoñedo en $1445^{\circ}$; no en vano Nuño Álvarez, en su testamento, además de dejar encargado al cabildo catedralicio conquense un aniversario por "su señor" el obispo Álvaro de Isorna, también encargó otro por "don Pedro de Vaamonde, mi señor, obispo que fue de Mondoñedo e provisor que fue deste obispado" 10 . De entre los familiares de Isorna, muchos de ellos originarios del ámbito gallego, los más favorecidos fueron inicialmente García Martínez Bahamonde, Pedro Vasco Bahamonde y el mencionado Pedro Arias Bahamonde, parientes del prelado, así como Juan Hurtado, deán de Burgos y arcediano de Huete en Cuenca, Rodrigo Bernal, arcediano de Alarcón, y el chantre de Cuenca Alfonso López ${ }^{11}$.

De esta etapa inicial en la carrera eclesiástica de Nuño Álvarez hay que destacar ante todo su participación en la embajada castellana al concilio de Basilea ${ }^{12}$, como auxiliar del obispo Álvaro Núñez de Isorna. En efecto, las intensas actividades diplomáticas en torno a la restauración de un poder pontificio plenamente legítimo se encaminaron hacia su definitivo final a partir de 1434, con la preparación del Concilio de Basilea. Ello supuso un esfuerzo último por parte de la diplomacia castellana y, en particular, de un buen número de eclesiásticos que durante los últimos años habían estado trabajando a fin de acelerar la llegada de esa solución. La larga duración del concilio y su propia importancia exigió de una nutrida representación eclesiástica castellana en el mismo. Los personajes principales de la embajada de Castilla en el concilio, que desempeñaban de hecho una posición de jefatura en la misma, estaban caracterizados por poseer una importante experiencia de representación exterior del rey de Castilla en muy diversas misiones, a la vez que por haber dado repetidas mues-

\footnotetext{
${ }^{8}$ Álvaro Núñez de Isorna, originario de la diócesis compostelana, había iniciado su carrera eclesiástica al amparo del arzobispo toledano don Pedro Tenorio, de quien era familiar. Fue nombrado en 1400 obispo de Mondoñedo, desde donde fue trasladado a León en 1415. NIETO SORIA, J. M., Iglesia y génesis..., pp. 134 y 443 . El 16 de marzo de 1418 Martín V le trasladó a la sede conquense, de la que fue titular hasta ser promovido al arzobispado de Santiago de Compostela el 7 de abril de 1445. ACC, original, s.s. / Archivio Segreto Vaticano (ASVat.), armario XII, vol. 121, f. 100; y Reg. Lat. 421, ff. 175v-176v. Falleció cuatro años más tarde, el 9 de febrero de 1449. BELTRÁN DE HEREDIA, V., Bulario de la Universidad de Salamanca, Salamanca, 1966, I, p. 289.

${ }^{9}$ EUBEL, C., Hierarchia Catholica..., vol. II, p. 212.

${ }^{10}$ ACC, Obras Pías, leg. 315, exp. $2 / 1$.

${ }^{11}$ BELTRÁN DE HEREDIA, V., Cartulario de la Universidad de Salamanca, Salamanca, 1970, I, pp. 349-353.

${ }^{12}$ Dos obras clásicas que todavía siguen siendo fundamentales para el estudio del pontificado de Eugenio IV y el problema del conciliarismo son las de GILL, J., Constance et Bâle-Florence, París, 1962; y STIEBER, J. W., Pope Eugenius IV, the council of Basel and the secular and ecclesiastical autorities in the empire. The conflict over supreme authority and power in the Church, Leiden, 1978.
} 
tras de adhesión personal al monarca. Este era el caso, sobre todo, de Álvaro Núñez de Isorna y de Alfonso de Cartagena ${ }^{13}$.

Tras recibir sus poderes en Valladolid el 13 de abril de 1434, los miembros de la diputación permanente de la embajada castellana llegarían a Basilea el 26 de agosto ${ }^{14}$. No obstante, desde el año anterior ya habían comenzado a llegar a Basilea otros eclesiásticos castellanos, entre ellos algunos de la iglesia conquense, como por ejemplo el maestrescuela Álvaro de Jarava y el arcediano de Cuenca Juan Carrillo, que se incorporaron el martes 10 de febrero de $1433^{15}$. Al principio se otorgó la presidencia de la embajada castellana al protonotario Alfonso Carrillo, por tratarse de un sobrino del cardenal fallecido meses antes, pero vista la deslealtad del mismo a las instrucciones recibidas del rey castellano, se acabaría prescindiendo de él, tomando entonces la dirección Isorna como prelado más antiguo de la embajada, quien después compartió esa función con Alfonso de Cartagena, promovido al obispado de Burgos en 1435. En las discusiones conciliares ambos tuvieron que enfrentarse repetidas veces con quienes trataban de restringir los poderes y derechos del papa, para de esta forma moderar la marcha del concilio. Durante el mismo, Isorna siempre se comportó como firme partidario del papa, tratando de llegar a un acuerdo con los conciliaristas ${ }^{16}$.

La embajada castellana se incorporó oficialmente al concilio el viernes 22 de octubre de 1434, el mismo día en que lo hizo la embajada inglesa, y entre los acompañantes y auxiliares del prelado conquense se encontraban Antonio Gil, doctor en Derecho canónico y canónigo de Cuenca, y Nuño Álvarez (de Fuente Encalada), por entonces bachiller en Decretos y también beneficiado en la iglesia conquense ${ }^{17}$, que seguramente llegó a Basilea desde Bolonia, donde es posible que llevase ya varios años estudiando Derecho.

Es esta referencia documental directa del año 1434 la primera que he conseguido encontrar sobre nuestro personaje, que por entonces aparece en las fuentes como bachiller en Decretos y beneficiado en la iglesia conquense. ¿Cuándo y dónde había obtenido este título universitario? Parece lógico pensar que hubiese sido algunos años

13 NIETO SORIA, J. M., Iglesia y génesis..., pp. 302-303. Sobre las relaciones del reino de Castilla con el concilio de Basilea durante estos años, hasta la deposición formal en 1439 del papa Eugenio IV, así como sobre el papel desempeñado por los embajadores castellanos en el desarrollo de las reuniones conciliares puede verse el reciente trabajo de VILLARROEL GONZÁLEZ, Ó., El rey y el papa. Política y diplomacia en los albores del Renacimiento (el siglo XV en Castilla), Madrid, 2009, pp. 187-254. Asimismo, el informe presentado en el concilio por la delegación castellana fue estudiado y publicado por ÁLVAREZ PALENZUELA, V. Á., La situación europea en época del concilio de Basilea. Informe de la delegación del reino de Castilla, León, 1992.

14 NIETO SORIA, J. M., Iglesia y génesis..., p. 302.

15 HALlER, J. (ed.), Concilium Basiliense. Studien und Quellen zur Geschichte des Concils von Basel. Band II: Protokolle des Concils 1431-1433, Basilea, 1897, p. 344. El último personaje citado, Juan Carrillo, que habría de coincidir con Nuño Álvarez tanto en Basilea como durante muchos años en la iglesia conquense, era pariente directo de Alfonso Carrillo de Albornoz, natural de Cuenca y cardenal de San Eustaquio desde 1408, quien también se incorporó al concilio con sus familiares ese mismo 10 de febrero de 1433, falleciendo al año siguiente.

16 BELTRÁN DE HEREDIA, V., Cartulario..., I, pp. 346-347.

17 “...dominus Nunius Alvari beneficiatus in ecclesia conchensi in decretis baccallarius". HALLER, J. (ed.), Concilium Basiliense. Studien und Quellen zur Geschichte des Concils von Basel. Band III: Protokolle des Concils 1434 und 1435, Basilea, 1900, p. 233. 
atrás en la universidad de Bolonia, residiendo en el colegio de San Clemente de esta ciudad, donde luego proseguiría sus estudios hasta alcanzar el Doctorado en Derecho canónico en 1438. Probablemente quienes le habían presentado para poder obtener una plaza en el colegio de San Clemente fueron su protector y "señor" el obispo Álvaro de Isorna y el cabildo catedralicio de Cuenca, pues de hecho la diócesis conquense, según los estatutos del colegio, tenía derecho a presentar cuatro candidatos para las plazas de que disponía la institución ${ }^{18}$. Estos estatutos, además, prescribían que las rentas anuales del candidato o colegial no pudiesen superar los 50 florines, pues la intención del cardenal Albornoz al fundar el colegio había sido que éste albergase a estudiantes que carecieran de medios económicos ${ }^{19}$, lo que vendría a corroborar la modesta condición social y económica de Nuño Álvarez en el momento de ingresar como colegial en la institución. Teniendo en cuenta que los estatutos establecían que los colegiales pudiesen permanecer durante ocho años antes de la obtención del grado de Doctor, y que Nuño Álvarez obtendría dicho grado en octubre de $1438^{20}$, es posible que su llegada al colegio se hubiese producido en torno al año 1430.

Respecto a su participación en las discusiones conciliares, consta que un año más tarde de su llegada a Basilea, el 12 de noviembre de 1435, Nuño Álvarez colaboró activamente en la defensa de la preeminencia castellana en el conflicto que, al igual que ya había sucedido en ocasiones anteriores, se originó sobre el asiento a ocupar en la reunión del concilio frente a la embajada inglesa, defendiendo los intereses castellanos en nombre del rey. Tal como queda recogido en las actas conciliares, ese día los embajadores del rey de Castilla reiteraron nuevamente su protesta por el lugar de inferior categoría que se les había asignado en los asientos del concilio, y acto seguido ascendieron a la banca donde se encontraban los embajadores ingleses y les expulsaron de allí violentamente ${ }^{21}$. Esa misma tarde Nuño Álvarez, que en las actas conciliares aparece mencionado como in utroque iure baccallarium -es decir, bachiller en Derecho canónico y civil-, presentó en el concilio una cédula de protesta en nombre del monarca castellano:

Eadem die hora III ${ }^{\mathrm{a}}$ post meridiem in deputacione pro communibus comparuit quidam Nunnius Alvari, dicens se esse in utroque iure baccallarium et procuratorem no-

${ }^{18}$ Para ser admitido como colegial en San Clemente de Bolonia había que ser oriundo de la Península Ibérica, clérigo o seglar, pero nunca religioso. Todo candidado debía llevar cartas de presentación de alguno de los obispos y cabildos a quienes los estatutos del colegio, fundado por el cardenal Gil de Albornoz, concedían el derecho de presentar candidatos en atención a los beneficios que en sus respectivas diócesis había poseído el cardenal. De las 30 ó 31 plazas de que disponía el colegio en esta época, las diócesis de Toledo y Cuenca eran las que tenían derecho a presentar más candidatos, cuatro cada una (dos canonistas, un teólogo y un médico). PÉREZ MARTÍN, A., Proles Aegidiana. I. Introducción ..., pp. 39-41. Cuando Nuño Álvarez estuvo residiendo en el colegio los estatutos por entonces vigentes eran los de 1377, los primeros que tuvo la institución. Dichos estatutos fueron publicados por BELTRÁN DE HEREDIA, V., "Primeros estatutos del colegio español de San Clemente en Bolonia", Hispania Sacra, 11 (1958), pp. 187-224, y 409-426.

${ }^{19}$ PEREZ MARTín, A., Proles Aegidiana. I. Introducción ..., p. 47.

${ }^{20}$ Ibídem, pp. 87 y 260.

21 "Ipsi ambassiatores ascenderunt ad bancham alciorem ad latus sinistrum et cum violencia expelerunt de prima sede, quam tenebant pacifice domini ambassiatores regis Anglie et specialiter dominus episcopus Aquensis, quem cum violencia a dicta sede eiecerunt...”. HALLER, J. (ed.), Concilium Basiliense. Studien und Quellen...Band III..., p. 565. 
mine domini regis Castelle et Legionis, produxit quandam cedulam, de qua protestacionis cedula peciit instrumentum et instrumenta ${ }^{22}$.

Durante el mes siguiente Isorna insistiría en que el concilio declarase que a los castellanos se les concedía el primer puesto después de Francia. Finalmente, el 6 de mayo de 1436, el concilio revocó sus acuerdos en materia de asientos, dejando a las partes en su derecho. Entonces los castellanos ocuparon el banco de la izquierda que tenían los ingleses, y sin resistencia de nadie los obispos de Cuenca y Burgos se colocaron después del patriarca de Aquileya, hasta que el 28 de julio el concilio asignó a los embajadores castellanos el primer lugar "in honore et voce" inmediatamente después de los franceses, ante lo cual, lógicamente, protestarían los representantes de Inglaterra y otros reinos ${ }^{23}$.

Mientras tanto, en enero de ese mismo año de 1436, Juan II había enviado a Florencia al deán conquense Pedro de Bocanegra, capellán del monarca, para informar a Eugenio IV de su decisión de permanecerle fiel fuese cual fuere el resultado del concilio, cuya agitación inspiraba al monarca grandes inquietudes. Para mayor firmeza de su adhesión, el rey otorgó a Bocanegra amplias facultades para "tractandi, firmandi pro nobis et nomine nostro regnorumque subditorum et adhaerentium nostrorum cum praefato sanctissimo Eugenio... amicitias, confederationes et ligas ad perpetuum vel ad tempus sub quacumque forma". Una vez cumplido el mandato regio, en julio de 1436 Pedro de Bocanegra dispuso el regreso a Castilla con su comitiva, compuesta de veinticinco personas ${ }^{24}$.

En relación con su participación en estas actividades diplomáticas debe ponerse la autorización que el 8 de julio de 1435 otorgó el concilio de Basilea al obispo Isorna para que pudiese disponer por testamento de la cantidad de hasta 12.000 florines de oro de cámara, procedentes de los bienes recibidos del rey o por herencia, o bien adquiridos por su trabajo personal, siempre y cuando no estuviesen vinculados al culto eclesiástico ${ }^{25}$, mientras que el 31 de mayo de 1436 el prelado solicitaría al concilio el otorgamiento de determinadas indulgencias a favor de la iglesia conquense ${ }^{26}$, siéndole finalmente concedidos, el 15 de junio, siete años y siete cuarentenas de perdón para las fiestas de la Natividad y Asunción de la Virgen ${ }^{27}$. Y respecto a su fiel auxiliar Nuño Álvarez, el concilio le concedió el 11 de marzo de 1435 que pudiese permutar ciertos beneficios con el clérigo conquense Juan de Huete, con el que al parecer tenía un litigio por este asunto ${ }^{28}$, y asimismo le confirmaría el viernes 14 de diciembre de 1436 en la posesión de cierto beneficio parroquial sine cura en la diócesis de Cuen-

${ }^{22}$ Ibídem, p. 565.

${ }^{23}$ BELTRÁN DE HEREDIA, V., "La embajada de Castilla al Concilio de Basilea", Hispania Sacra, X (1957), pp. 10-27.

${ }^{24}$ BELTRÁN DE HEREDIA, V., Cartulario..., I, pp. 360-361.

${ }^{25}$ Ibídem, p. 348.

${ }^{26}$ HALLER, J. (ed.), Concilium Basiliense. Studien und Quellen zur Geschichte des Concils von Basel. Band IV: Protokolle des Concils von 1436, Basilea, 1903, p. 156.

${ }^{27}$ Ibídem, pp. 178-179.

${ }^{28}$ HALlER, J. (ed.), Concilium Basiliense... Band III: Protokolle des Concils 1434 und 1435, p. 334 Dicha autorización para realizar la permuta sería reiterada de nuevo el 30 de junio y el 8 de julio, para que liter inter eos extinguat. Ibídem, pp. 421 y 436. 
ca, que le había sido otogado con anterioridad por el obispo Isorna ${ }^{29}$. Algún tiempo después, en mayo de 1438, Eugenio IV también concedía a Juan Carrillo, arcediano de Cuenca, que en 1433 había participado asimismo en las reuniones conciliares, el arcedianato de Ledesma, en atención a una súplica del rey de Castilla, de quien era capellán $^{30}$ y el 6 de agosto de ese mismo año de 1438, previa súplica del obispo Álvaro de Isorna, el concilio confirmó a Gonzalo de Párraga en la posesión de la iglesia parroquial de San Pedro, en la ciudad de Cuenca, de la cual el prelado previamente le había hecho colación ${ }^{31}$.

Todavía habrían de continuar algún tiempo más las labores diplomáticas del obispo Álvaro de Isorna, si bien nada mencionan las fuentes sobre la presencia en ellas de Nuño Álvarez como auxiliar del prelado. Así, en la primavera de 1439, Isorna acudiría a la dieta de Maguncia en representación del reino de Castilla, siendo uno de los más acérrimos impulsores de las tentativas de acuerdo entre los representantes del concilio y los del papa ${ }^{32}$, a pesar de los cual éste sería depuesto el 25 de junio ${ }^{33}$. En julio de este mismo año de 1439 Álvaro de Isorna se encontraba en Estrasburgo con la legación castellana, en espera de órdenes de Juan $\mathrm{II}^{34}$, que finalmente mandó la retirada de Castilla del concilio. Así, Castilla no participó oficialmente en el concilio de Ferrara-Florencia que se inició en 1438, aunque seguramente sí contó con un observador, si bien apoyó abiertamente a Eugenio IV frente al antipapa Félix V, esforzándose el monarca por conseguir que los castellanos que se habían quedado en Basilea tuviesen una postura moderada ${ }^{35}$.

Tras su participación en el concilio de Basilea entre 1434 y 1436, Nuño Álvarez volvió seguramente no más tarde de este último año a Bolonia para completar sus estudios en la universidad, continuando su residencia en el colegio de San Clemente, fundado en el siglo anterior por el cardenal Gil Álvarez de Albornoz, y doctorándose en Derecho canónico el 16 de octubre de 1438. Lo presentó Juan de Tomaris, obteniendo el Grado en la sacristía nueva de San Pedro, en Bolonia ${ }^{36}$. Su paso por

29 "Super supplicacione Nuni Alvari possessoris beneficii sine cura de Touropucillo Conchensis diocesis petentis collacionem sibi per reverendum patrem dominum Conchensem...per idem sacrum concilium confirmari et, si opus fuerit, de novo provideri cum supplecione defectuum, etc. Concordant...quod admittatur et admissa est hiusmodi requesta in forma ut petitur...". HALLER, J., BECKMANN, G. (eds.), Concilium Basiliense. Studien und Quellen zur Geschichte des Concils von Basel. Band VI: Protokolle des concils vom dezember 1436-dezember 1439, Basilea, 1925, p. 1.

30 VILLARROEL GONZÁLEZ, Ó, "Capilla y capellanes al servicio del rey de Castilla. La evolución en época de Juan II (1406-1454)”, En la España Medieval, 31 (2008), p. 318. Este personaje fue pariente tanto del cardenal Alfonso Carrillo de Albornoz como probablemente del arzobispo de Toledo Alfonso Carrillo de Acuña. Ibídem, p. 339.

${ }^{31}$ HALlER, J., BECKMANN, G. (eds.), Concilium Basiliense... Band VI, p. 289.

32 BELTRÁN DE HEREDIA, V., Bulario..., I, p. 108. En Maguncia hubo una nutrida representación castellana, tanto entre los representantes del concilio como entre los del papa, además de los propios embajadores regios. Juan Alfonso de Segovia era la cabeza teológica de los conciliares, Juan de Torquemada hacía lo propio entre los pontificios, y Alfonso de Cartagena y Álvaro de Isorna fueron los embajadores regios. VILLARROEL GONZÁLEZ, El rey y el papa..., p. 259.

33 VILLARROEL GONZÁLEZ, Ó, El rey y el papa..., p. 216.

34 BELTRÁN DE HEREDIA, V., Cartulario..., I, p. 348.

35 VILLARROEL GONZÁLEZ, Ó., El rey y el papa ..., pp. 255-257.

36 PÉREZ MARTíN, A., Proles Aegidiana I. Introducción. Los colegiales desde 1368 a 1500, p. 260. 
esta universidad hay que situarlo en el contexto de la creciente afluencia a sus aulas durante la baja Edad Media de clérigos de origen hispánico, fundamentalmente para la realización de estudios de Derecho canónico, y en menor medida de Teología; para el caso concreto de la diócesis conquense, hay documentados al menos 41 clérigos originarios de la misma que estudiaron en Bolonia residiendo en el colegio de San Clemente desde su fundación en 1368 hasta $1500^{37}$. Juan de Pineda y Hurtado de Mendoza, historiador del colegio, nos ofrecía en el siglo XVII el siguiente bosquejo biográfico de nuestro personaje:

Alter fuit don Nunius Alvarez Ossorio V.I.D. oppidi de Fuentencalada, dioecesis Astoricensis, ex illustri familia marchionum de Astorga, Sancti Clementis alumnus et Rector (licet non appareat de anno quo dignitate Rectorali functus fuerit ob defectum librorum), postea canonicatu et cantoris dignitate in ecclesia cathedrali Conchensi functus fuit. Floruit circa annum ab Orbe redempto 1476, magna vitae austeritate, et sacramentorum frecuentia excelluit, pariterque doctrina claruit. Patrimonium suum et reditus ecclesiasticos pauperibus erogavit, archiepiscopatum Compostellanum aliasque dignitates ultro sibi oblatas Procter humilitatem acceptare noluit. Erexit in civitate Conche monasterium monialium Benedictinarum, quod hodie extat. Nostri Collegii Sacellum quinquaginta scutatis aureis elargitis et alia plura loca pia refecit et aedificavit, maxime Sacellum D. Michaelis in preadicta cathedrali, capellaniis et divini ornamentorum suppellectile dotatum, ubi ipse hodie immutationem expectat, et magna cum reverentia ac pietate veneratur, necnon ingenti devotione visitatur. Plura de hoc viro refert Villegas in 3 par. Flor. Sanct. vita 200 et ipsius vitae compendium manuscriptum a Doctore Ildephonso Grijalva canonico Burgen. (qui, et graviora opuscola de sacramentis edidit) in Bibliotheca Collegi nostri repositum comperitur, ubi latius per plura capita charitatem, pietatem, humilitatem, denique cordis puritatem, huiusce viri latius persequitur. Obiit die 14 augusti anno 1477, vixit annos $76^{38}$.

Aunque tradicionalmente se le ha atribuido el haber sido rector del colegio de San Clemente $^{39}$, lo cierto es que, según se recoge en el testimonio biográfico anterior, en la documentación y libros administrativos del colegio no figura el año en que pudo haber ejercido dicho cargo. Es posible incluso que en realidad nunca lo ejerciese, y que la atribución del cargo a Nuño Álvarez se deba a una confusión con su sobrino Luis de Fuente Encalada, que seguro fue rector del colegio al menos durante los años 1458-1459 y 1461-1463, y en cuyo rectorado parece ser que se consiguió sanear un poco la precaria economía del colegio ${ }^{40}$. En todo caso Nuño Álvarez sería recordado como bienhechor del colegio de San Clemente por la donación que hizo al mismo de

${ }^{37}$ AGUADÉ NIETO, S.; CABAÑAS GONZÁLEZ, M. D., "La formación intelectual del clero conquense a fines de la Edad Media", en Actas del Simposio sobre el horizonte histórico-cultural del Viejo Mundo en vísperas del Descubrimiento de América (Cuenca, 21-24 de mayo de 1979), Madrid, 1981, p. 19.

38 PINEDA Y HURTADO DE MENDOZA, J. de., op. cit., pp. 9-10. Cfr. PÉREZ MARTÍN, A., Proles Aegidiana I..., pp. 260-261.

39 Así lo señala también su primer biógrafo conquense, Vida del Venerable don Nuño Álvarez..., ACC, Obras Pías, leg. 315, exp. 3.

40 PÉREZ MARTÍN, A., Proles Aegidiana I..., pp. 260 y 292-293. Luis de Fuente Encalada fue presentado por el cabildo catedralicio conquense y por el entonces obispo Lope de Barrientos para estudiar Teología en el colegio, siendo recibido el 28 de mayo de 1454 por Pedro de Herrera. En 1459 y 1460 aparece en ocasiones como consiliario. Además amplió la biblioteca del colegio con toda la habitación teologal. Ibídem, pp. 292- 
50 ducados de oro, con los que se compraron diversos ornamentos y objetos litúrgicos para su empleo en las celebraciones más solemnes ${ }^{41}$.

\section{EL CHANTRE NUÑO ÁLVAREZ COMO SERVIDOR Y BENEFACTOR DE LA IGLESIA CONQUENSE}

Resulta difícil determinar si Nuño Álvarez, tras alcanzar el grado de Doctor en Derecho canónico en Bolonia a fines de 1438, se instaló de inmediato en la iglesia conquense. Su primer biógrafo nos dice en varias ocasiones que el chantre permaneció un total de treinta y seis años en Cuenca, y que murió con setenta y seis años ${ }^{42}$, por lo que, dado que falleció en 1476 , su llegada a la ciudad habría tenido lugar hacia 1440, si bien el biógrafo indica equivocadamente el año 1477 como el de su muerte. También según su primer biógrafo, había sido promovido a las órdenes sagradas que tenía en Roma, durante sus años de estancia en Italia, aunque en otro lugar el mismo autor dice que al llegar a Cuenca desde Bolonia fue promovido a la dignidad sacerdotal y el obispo Álvaro de Isorna le hizo chantre y canónigo de la iglesia conquense, otorgándole otros beneficios en la diócesis ${ }^{43}$. Sea como fuere, parece posible que no mucho después de su llegada a Cuenca obtuviese una canonjía en el cabildo catedralicio, y luego la dignidad de chantre, siempre gracias a la mediación de su protector, el obispo Isorna, que según hemos dicho tenía facultad pontificia para conceder beneficios vacantes a sus familiares, y que de este modo le recompensaba por la eficaz ayuda prestada en el transcurso de las difíciles y arduas tareas conciliares en Basilea. Por otro lado, no es en absoluto casual que el anterior titular de la chantría en Cuenca, el clérigo Alfonso López, fuese también un familiar de Álvaro de Isorna, según figura en una súplica del año $1435^{44}$. En todo caso, según veremos más adelante, en enero de 1442 Nuño Álvarez ya figura como chantre asistiendo al sínodo diocesano convocado por el obispo Isorna, y es probable que su posesión de la chantría se remonte a algún tiempo atrás, manteniéndose como titular de esta dignidad hasta su muerte en 1476.

La creación de esta dignidad se remontaba a la etapa inicial del cabildo catedralicio conquense, y probablemente tuvo lugar a fines del siglo XII o durante la primera mitad de la siguiente centuria ${ }^{45}$. Durante el rezo de las horas ocupaba el segundo lugar en el Coro del obispo, a continuación del arcediano de Cuenca, debía

293. En su testamento de 1476, Nuño Álvarez designaría a este sobrino suyo como heredero universal y patrono de su capilla de San Miguel en la catedral conquense, según veremos más adelante.

${ }^{41}$ Ibídem, p. 260.

${ }^{42}$ ACC, Obras Pías, leg. 315, exp. 3.

${ }^{43}$ ACC, Obras Pías, leg. 315, exp. 3.

${ }^{44}$ Entre otros familiares de Álvaro de Isorna que aparecen en una súplica beneficial al papa datada el 26 de abril de 1435 se encuentran Juan Hurtado, deán de Burgos y arcediano de Huete en el cabildo catedralicio conquense; Rodrigo Bernal, arcediano de Alarcón también en Cuenca; y el mencionado chantre conquense, Alfonso López. BELTRÁN DE HEREDIA, V., Cartulario..., I, pp. 352-353.

${ }^{45}$ Véase mi artículo "El cabildo catedralicio conquense en el siglo XIII", Anuario de Estudios Medievales, 27/1 (1997), p. 318. 
ser presbítero ${ }^{46}$, y su misión era dirigir gran parte de las actividades del coro y organizar la ejecución del canto litúrgico, función en la que frecuentemente le sustituía un sochantre, que era un delegado que actuaba en nombre del chantre cuando este último estaba ausente ${ }^{47}$. Hay que poner de relieve el interés que el obispo Álvaro de Isorna mostró por mejorar las rentas de la chantría y la tesorería del cabildo catedralicio conquense. Así, respecto a la primera, y de acuerdo con el cabildo, determinó que se le anejasen, conforme quedaran vacantes, los préstamos de Alcañate, Santa María del Campo y Santa María de Alcocer, que pertenecían a Lope Hurtado de Mendoza, arcediano de Huete ${ }^{48}$.

Según su primer y anónimo biógrafo, en algún momento a Nuño Álvarez se le ofrecieron dignidades mayores e incluso ser obispo en Galicia, a lo que habría renunciado por humildad $d^{49}$, mientras que otro biógrafo posterior, Salvador Silvestre de Velasco y Herrera, llega a decir que el chantre renunció hacia el final de su vida al arzobispado de Santiago, mitra de la que habría llegado a ser electo ${ }^{50}$, pero lo cierto es que sobre todo ello no contamos con ningún tipo de respaldo documental, debiendo ponerse muy en duda su veracidad, máxime si tenemos en cuenta que, tras su llegada a Cuenca, Nuño Álvarez se desvinculó casi por completo de los grandes círculos de poder político y eclesiástico, sin cuyo apoyo difícilmente habría podido obtener una mitra tan sumamente relevante como era la de Santiago de Compostela, controlada en esos momentos por los obispos Fonseca ${ }^{51}$.

La permanencia de Nuño Álvarez en la iglesia conquense coincidió con el final del pontificado del obispo Álvaro Núñez de Isorna (1418-1445), con todo el de Fray Lope de Barrientos (1445-1469), y con buena parte del pontificado del cardenal Antonio Jacobo de Veneris (1469-1479). Algunos eclesiásticos relevantes, a nivel local, que también formaron parte del cabildo catedralicio conquense durante estos años fueron, por ejemplo, Nicolás Martínez de la Campana, bachiller en Decretos, arcediano de Miñor y luego arcediano de Moya, probable familiar de Álvaro de Isorna, vicario general del obispado en varias ocasiones y, al menos entre 1460 y 1476, deán del cabildo ${ }^{52}$; Pedro Arias Bahamonde, familiar de Álvaro

${ }^{46}$ Constituciones sinodales del obispado de Cuenca de 1446, Biblioteca del Colegio de Santa Cruz de Valladolid, Ms. 340, f. 4r.

${ }^{47}$ Uno de los testimonios más antiguos que se conservan sobre la existencia de un sochantre en Cuenca data del 18 de julio de 1302, fecha en la cual el cabildo catedralicio vendió en almoneda a Alvar Sánchez, canónigo y sochantre de la catedral, unas casas en la "calleja del Canto", al precio de 600 maravedís. ACC, Institucional, caja $12, \mathrm{n}^{\circ} 8$.

48 Constituciones sinodales del obispado de Cuenca de 1446, f. 15v.

49 Este primer biógrafo del chantre nos dice: "Ví que lo llamaron e rogaron que fuese a ser obispo en Galiçia, e le davan otras dignidades mayores, e non las quiso açebtar por sola devoçión”. ACC, Obras Pías, leg. 315 , exp. 3 .

50 SILVESTRE DE VELASCO Y HERRERA, S., op. cit., p. 194.

${ }^{51}$ En las series episcopales de C. Eubel no figura que fuese electo de Santiago, mientras que las crónicas castellanas tampoco mencionan que fuese presentado para esta diócesis. Es posible que la confusión se deba al hecho de que al obispo de Ávila Lope de Barrientos el monarca le ofreció en febrero de 1445 trasladarse a Santiago, pero el prelado rechazó la oferta, siendo trasladado finalmente a Cuenca, y el obispo Álvaro de Isorna a Santiago. BELTRÁN DE HEREDIA, V., Cartulario..., I, p. 348.

${ }^{52}$ Véase mi libro Iglesia, sociedad y poder en Castilla. El obispado de Cuenca en la Edad Media (siglos XII-XV), Cuenca, 2003, p. 650. 
de Isorna, deán de Orense y vicario general del obispado de Cuenca entre 1429 y $1444^{53}$, que un año después sería nombrado obispo de Mondoñedo; Ruy Gómez de Anaya, arcediano de Alarcón entre 1446 y 1470, año de su muerte ${ }^{54}$; o Gabriel Condulmario, Doctor en leyes, antiguo referendario y escribano de la cancillería apostólica $^{55}$, familiar y vicario del cardenal Veneris en el obispado conquense desde 1470, protonotario apostólico y arcediano de Alarcón al menos desde $1474^{56}$. Y entre los personajes que sucedieron a Nuño Álvarez como titulares de la chantría puede destacarse, entre otros, a Pedro de Villalobos, cuyas rentas beneficiales fueron secuestradas por orden regia en 1480 al ser considerado persona desleal a la corona $^{57}$; a Alonso Yáñez, de familia judeoconversa, que ejercía el cargo en $1492^{58}$; y a Juan de Guzmán, chantre en $1495^{59}$.

A lo largo de su dilatada estancia en la iglesia conquense Nuño Álvarez desempeñó diferentes cargos administrativos vinculados al cabildo catedralicio. Por ejemplo, el 26 de noviembre de 1449 fue nombrado contador de los vestuarios del coro del obispo para el año siguiente, junto al canónigo Nicolás Martínez de la Campana ${ }^{60}$. Y en 1464 ejerció el oficio de limosnero del Arca de la Limosna, institución asistencial dependiente del cabildo ${ }^{61}$, similar a la que algunas décadas después se crearía en el cabildo catedralicio toledano ${ }^{62}$.

53 Ibídem, p. 642.

${ }^{54}$ Ibídem, p. 647.

${ }^{55}$ FRENZ, Th., Repertorium Officiorum Romanae Curiae. Conspectus generalis personarum alphabeticus secundum ordinem pranominum, littera G, instrumento en la red (http://wwws.phil.uni-passau.de/histhw/ RORC/littera_G.html).

56 Véase mi libro Iglesia, sociedad y poder..., pp. 123, 472 y 644.

${ }^{57}$ El 30 de septiembre de 1480, estando vacante la sede episcopal conquense, los Reyes Católicos mandaron al regidor conquense Alfonso de Alcalá secuestrar las rentas de los beneficios eclesiásticos pertenecientes al arcediano de Cuenca Gómez Ballo y al chantre Pedro de Villalobos, que según los monarcas "fisieron e cometieron algunas cosas en deserviçio nuestro e contra nuestra real preheminençia e en menospreçio de nuestras cartas e mandamientos", siendo por ello también castigados con la pérdida de naturaleza del reino. Archivo General de Simancas, Registro General del Sello, 30-IX-1480, f. 158.

58 LORENZO CADARSO, P. L., "Esplendor y decadencia de las oligarquías conversas de Cuenca y Guadalajara (siglos XV y XVI), Hispania, LIV/1, 186 (1994), pp. 57-58.

59 Véase mi citado libro Iglesia, sociedad y poder en Castilla. El obispado de Cuenca..., p. 647.

${ }^{60}$ Ese mismo día también se nombró, para el año siguiente, a los contadores de los vestuarios del coro del deán, recayendo el cargo en el maestrescuela Álvaro de Jaraba y el canónigo Sancho Ruiz, designándose asimismo a los contadores de las pitanzas del coro del obispo y del deán. ACC, Actas Capitulares de 1449, f. $105 \mathrm{r}-\mathrm{v}$.

61 ACC, Actas Capitulares de 1489, ff. 18r-19v. Se trata de una relación de miembros del cabildo catedralicio que fueron limosneros entre 1455 y 1485. Sobre el Arca de la Limosna, ya documentada a comienzos del siglo XV, puede verse mi trabajo "Pobreza y marginación en la Castilla bajomedieval. Notas sobre el ejercicio de la caridad en Cuenca a fines de la Edad Media", Anuario de Estudios Medievales, 24 (1994), pp. 887-924, y particularmente pp. 905-921.

${ }^{62}$ La llamada Arca de la Limosna del pan del claustro fue creada en 1490 por el cabildo catedralicio de Toledo, con el apoyo económico del cardenal Mendoza, para distribuir diariamente pan en el claustro de la catedral a un número de pobres fuese cual fuese su condición. LOP OTÍN, M. J., El cabildo catedralicio de Toledo en el siglo XV. Aspectos institucionales y sociológicos, Madrid, 2003, pp. 365-366. 
Hay que destacar la presencia del chantre en todos los sínodos diocesanos que se celebraron mientras duró su prolongada permanencia en la iglesia conquense. Estuvo en el convocado por el obispo Álvaro de Isorna el miércoles 10 de enero de 1442, que se celebró en la catedral de Cuenca, y que fue el único sínodo que hubo en época de este prelado ${ }^{63}$ :

...En la yglesia cathedral de la noble çibdad de Cuenca, miércoles, diez días del mes de enero del año de la natividad de nuestro señor Jesuchristo de mill e quatroçientos e quarenta e dos años, estando ende en el choro de la dicha yglesia el muy reverendo in Christo padre e señor don Álvaro de Ysorna, por la graçia de Dios e de la sancta yglesia de Roma obispo de Cuenca, oydor de la Audiençia de nuestro señor el rey e uno de los del su consejo, en pontifical, assentado çelebrando sancta sínodo, e estando ende presentes los honrados don Juan Alfonsso de Oña, abad de Sanctiago, lugarteniente de deán por el honrado varón don Pedro Bocanegra, deán de la dicha yglesia, e don Juan Carrillo, arçidiano de Cuenca, e don Nuño Alvarez de Fuentencalada, doctor en Decretos, chantre de la dicha yglesia, e don Ruy Bernal, arçidiano de Alarcón, e don Martín López de Frías, thesorero, e don Pedro Arias de Vaamonde, deán de Orense e arçidiano de Bivero, provisor del dicho señor obispo, e Rodrigo Arias Maldonado e Françisco Bordallo e don Nicholás Martínez de la Campana, arçidiano de Miñor... ${ }^{64}$.

Si se observa el origen geográfico de algunas de las mencionadas dignidades del cabildo catedralicio conquense que estuvieron presentes en este sínodo celebrado por Álvaro de Isorna, llama sin duda la atención su procedencia del ámbito gallego y leonés, que es de donde eran originarios la mayoría de los familiares y nepotes de Isorna, varios de los cuales, entre ellos Nuño Álvarez, gracias a la mediación del prelado acabarían estableciéndose en la iglesia conquense ocupando cargos de relieve en el cabildo catedralicio. Por otro lado hay que destacar el empleo del don delante de los nombres del obispo y de las dignidades catedralicias que asistieron al sínodo. El "don", como fórmula de preeminencia social, aparte de ser utilizado por los miembros de la nobleza laica, para los eclesiásticos estaba en íntima relación con su posición dentro de la jerarquía eclesiástica, de modo que lo empleaban los abades, deanes, dignidades catedralicias, obispos y arzobispos ${ }^{65}$. En cambio los nombres de los simples canónigos, arciprestes y vicarios presentes en el sínodo no van precedidos de la fórmula "don" 66 .

Asimismo, consta también la asistencia de Nuño Álvarez a los dos sínodos celebrados en época del obispo Lope de Barrientos: el que se reunió en la catedral el domingo 19 de junio de 1446, y donde se publicaron unas amplísimas constituciones

${ }^{63}$ Las actas de este sínodo se encuentran recogidas en: ACC, Libro de Estatutos, ff. 87r-94v. Los sínodos medievales del obispado de Cuenca han sido recientemente editados en la colección Synodicon Hispanum (dir. GARCÍA Y GARCÍA, A.), vol. X (Cuenca y Toledo), Madrid, B.A.C., 2011. El sínodo de Álvaro de Isorna, concretamente, en pp. 184-203.

${ }^{64}$ Synodicon Hispanum, vol. X, pp. 184-185.

${ }^{65}$ ANTONIO RUBIO, M. G. de, "Judíos, conversos e inquisición en Galicia (siglos XI-XVII)", Cuadernos de Estudios Gallegos, LVI/122 (2009), p. 178.

66 Synodicon Hispanum, vol. X, p. 185. 
para la reforma y mejora de las costumbres del clero y laicos de la diócesis ${ }^{67}$; y el celebrado también en la catedral conquense durante los días 1 y 2 de mayo de 1457 , donde se confirmaron las constituciones del sínodo anterior y se publicaron otras nuevas ${ }^{68}$.

En época del siguiente titular de la mitra conquense, el cardenal absentista Antonio Jacobo de Veneris (1469-1479), que jamás se personó en el obispado, únicamente sabemos de la celebración de un sínodo sobre el que hasta ahora no teníamos ninguna noticia ${ }^{69}$. La única y breve referencia al respecto es la que aparece recogida en el libro de pitancería de la catedral del año 1477, donde se señala que el domingo 24 de agosto de dicho año -Nuño Álvarez ya había fallecido- el protonotario apostólico Gabriel Condulmario, que gobernaba la diócesis en nombre del cardenal Veneris, celebró sínodo en la catedral, al que asistieron, además de los miembros del cabildo, los arciprestes y vicarios de la diócesis ${ }^{70}$. Parece lógico que en dicho sínodo se promulgasen algún tipo de constituciones, pero lo cierto es que, de haber sido así, estas no han llegado hasta nosotros.

En ocasiones encontraremos a nuestro personaje defendiendo los intereses económicos del clero de la diócesis conquense frente a las exigencias fiscales del papado y de la corona castellana. En 1460, por ejemplo, sin haber finalizado aún la recaudación en Castilla de un subsidio anterior, Pío II impuso una nueva décima sobre las rentas eclesiásticas para financiar la lucha contra el turco, de cuyo montante Enrique IV podría retener una tercera parte, así como la mitad de lo recaudado por la cruzada ${ }^{71}$. Como reacción contra este nuevo tributo, el 12 de septiembre de 1462 se celebró en el obispado de Cuenca una reunión del cabildo catedralicio con los arciprestes, vicarios y representantes del clero secular y regular de la diócesis, en la cual el chantre Nuño Álvarez presentó unos acuerdos que habían hecho todos los obispos de Castilla en contra de la décima. En la mencionada reunión diocesana también se puso de manifiesto la oposición generalizada que existía contra el colector y legado pontificio Antonio Jacobo de Veneris -futuro titular de la mitra conquense-, y se nombraron procuradores para que acudiesen en representación de la iglesia de Cuenca a una congregación del clero castellano que próximamente iba a celebrarse, para exponer al rey su oposición al pago de la décima ${ }^{72}$. Dicha congregación se reunió en Salamanca el 8 de noviembre de ese mismo año, acordándose solicitar una entrevista con Enrique $\mathrm{IV}$, ante quien debería comparecer una comisión formada por los obispos de Burgos y Salamanca a fin de presentarle las quejas referidas respecto a lo abusivo que consideraban que se les impusiera una nueva décima. Estas gestiones darían lugar a que, a petición del rey, el papa ordenase a los colectores que redujesen en lo posible la décima que estaban recolectando, la cual, finalmente, se convertiría en un subsidio que

${ }^{67}$ Constituciones sinodales del obispado de Cuenca de 1446, f. 2r. Ed. Synodicon Hispanum, vol. X, pp. 205-343.

68 Constituciones sinodales del obispado de Cuenca de 1457, Biblioteca del Colegio de Santa Cruz de Valladolid, Ms. 340, f. 129r. Ed. Synodicon Hispanum, vol. X, pp. 343-356.

69 Ningún dato al respecto aparece en la mencionada reciente edición de los sínodos medievales conquenses recogida en Synodicon Hispanum, vol. X.

${ }^{70}$ ACC, Pitancería, 1477, f. 116v.

71 NIETO SORIA, J. M., Iglesia y génesis, p. 333.

72 ACC, caj. 7, leg. 38, no 766. 
representaría una cantidad muy inferior a la inicialmente prevista, y que se situaría en 100.000 florines $^{73}$.

Poco tiempo después, en 1464, durante la profunda crisis política que atravesó el reino de Castilla a causa del alzamiento de parte de la nobleza y el clero contra Enrique IV y a favor del príncipe don Alfonso, el chantre Nuño Álvarez no dudó en ofrecer claras muestras de su apoyo a Enrique IV, siguiendo así la misma línea de actuación que en el transcurso de estos acontecimientos manifestó el conjunto del clero conquense, encabezado por el obispo Lope de Barrientos. Ese mismo año, ante el cariz que tomaban los acontecimientos, el rey movilizó a las hermandades, poniéndolas en guardia ante la inminencia de un levantamiento, y en esta búsqueda de fidelidades y de utilización de las hermandades en defensa del poder real se incluyó también la llamada al obispo Lope de Barrientos, que se reincorporó al Consejo Real, jugando un importante papel en la coordinación y puesta a punto de las hermandades ${ }^{74}$. En efecto, el 21 de septiembre de 1464, Enrique IV mandaría a los concejos de Cuenca, Huete, Uclés, Requena, Moya y Huélamo que se uniesen en hermandad bajo la dirección del obispo Barrientos, y que todos sus procuradores se reuniesen en la ciudad de Cuenca para la realización de dicha hermandad de mutua protección en defensa de la autoridad real, dados los recientes escándalos acaecidos en el reino ${ }^{75}$.

Además, ese mismo día, a raíz del reciente alzamiento que había tenido lugar en Valladolid contra Enrique IV, Lope de Barrientos compareció ante el concejo de Cuenca para exponer su deseo de que la ciudad permaneciese fiel al rey, a quien deberían hacer juramento de fidelidad aquellos que deseasen permanecer en Cuenca. De este modo, acto seguido todos los presentes juraron permanecer fieles a Enrique IV y defender firmemente la ciudad en favor de la autoridad real. Entre los que realizaron dicho juramento destacaban las siguientes personas, aparte del propio obispo: el corregidor de Cuenca, Pedro de Salcedo, y los regidores de la ciudad; el deán de la catedral, Nicolás Martínez de la Campana; el arcediano de Cuenca, Juan Carrillo; el chantre Nuño Álvarez de Fuente Encalada; el provisor de la diócesis, Alfonso García de San Felices; el arcediano de Alarcón, Ruy Gómez de Anaya; Francisco Bordallo, abad de la Sey; el bachiller Ferrand Sánchez de Cuenca; y otros eclesiásticos y vecinos de la ciudad ${ }^{76}$.

El prestigio de la dignidad que ostentaba Nuño Álvarez en el cabildo catedralicio conquense explica probablemente su ocasional nombramiento como juez en pleitos diversos. Para el año 1474 contamos con dos ejemplos al respecto. Así, el 24 de febrero de este año Nuño Álvarez actuó como juez comisario en un pleito entre el monasterio cisterciense de Santa María de Monsalud, situado en la diócesis conquense, y el clérigo Juan de Torres, arrendador de las rentas decimales de pan de un beneficio curado que el monasterio tenía en el lugar de Salmeroncillo, aldea de Huete, y que los cistercienses reclamaban para sí, dictaminando finalmente que dichos diezmos

\footnotetext{
${ }^{73}$ NIETO SORIA, J. M., Iglesia y génesis..., p. 334.

${ }^{74}$ NIETO SORIA, J. M., Iglesia y génesis..., p. 278.

75 Archivo Municipal de Cuenca, leg. 196, exp. 2, ff. 115v-116r.

76 Ibídem, ff. 107r y ss.
} 
fuesen entregados al monasterio, a quien pertenecían ${ }^{77}$. Y un mes más tarde, el 31 de marzo, intervino como juez, junto con el arcediano de Alarcón Gabriel Condulmario y el tesorero Gonzalo Barroso, en el pronunciamiento de una sentencia arbitral en cierto pleito que había entre Pedro Carrillo de Albornoz, señor de Torralba y Beteta, y Pedro de Alarcón, señor de Valverde ${ }^{78}$.

Pero, aparte del desempeño de las diversas labores eclesiásticas que se han mencionado, probablemente la faceta que más debe destacarse en la figura del chantre Nuño Álvarez es la de haber sido un importante benefactor de la iglesia conquense, y más particularmente del cabildo catedralicio del que formaba parte. Ello se pone de manifiesto tanto a través de su testamento, del que se hablará más adelante, como en una importante donación al cabildo que realizó el chantre el 27 de marzo de 1450, y que ha quedado recogida en el Necrologio-Obituario, un códice misceláneo conservado en el Archivo catedralicio conquense ${ }^{79}$. Dicha donación fue estudiada y publicada por el profesor José Trenchs Odena, quien consideró que se trataba del testamento del chantre Nuño Álvare $z^{80}$, si bien en realidad el testamento se otorgaría muchos años después, concretamente el 7 de agosto de $1476^{81}$. La importancia de esta donación radica sobre todo en que en ella se recogen los títulos de varias decenas de libros que el chantre había legado en vida al cabildo catedralicio, reservándose el usufructo de los mismos mientras viviese. De estos libros, que conformaban el contenido fundamental de la biblioteca particular de Nuño Álvarez, se hablará más adelante.

Además de libros, en la donación de 1450 el chantre también dejó otros bienes al cabildo catedralicio. Primeramente, algunas importantes cantidades de dinero: diez mil maravedís tras su muerte, y mil maravedís anuales que pagaría en vida, para que con ellos y con lo que se obtuviese de la venta de algunos libros que estaban repetidos el cabildo pudiese comprar una propiedad perpetua sobre la que situar cinco aniversarios; otros cinco mil maravedís, también después de su muerte, destinados a las pitanzas de la maitinada ordinaria de cada día "en satisfacción de las horas non bien ganadas nin bien dichas o dexadas...", debiendo el cabildo respetar la costumbre según la cual tenían que rezarse maitines de finados en el coro. Asimismo, donó al cabildo varios utensilios y ajuar doméstico diverso: dos cubas grandes y una mediana para vino que estaban en la bodega de su casa, más un tino pequeño, en satisfacción de las distribuciones mal ganadas; una cama de madera con sus tablas, que se encontraba en la cámara en que dormía; otra cama con sus tablas y un banco, una mesa de comer con sus pies y con otro banco, más otros muebles sin especificar que tenía en su casa de Cólliga; para la fábrica y ornamentos de la catedral dejó dos paños de ras

77 Archivo Histórico Provincial de Cuenca (en adelante: AHPC), olim Desamortización, leg. 298; ed. DÍAZ IBÁÑEZ, J., "Santa María de Monsalud. Reconstrucción histórica de un cenobio cisterciense (siglos XII-XVI)", Cistercium, XLVII/201 (1995), pp. 460-461.

${ }^{78}$ LASSO DE LA VEGA, M., El señorío de Valverde, Madrid, 1945, doc. $\mathrm{n}^{\circ} 37$.

${ }^{79}$ Un estudio de este códice y de su contenido principal es el que realizó el profesor TRENCHS ODENA, J., "El Necrologio-Obituario de la catedral de Cuenca", Anuario de Estudios Medievales, 12 (1982), pp. 341379.

${ }^{80}$ TRENCHS ODENA, J., "La cultura jurídico-piadosa del cabildo conquense (1450-1476)", en Livre et lecture en Espagne et en France sous l'ancien Régime, Madrid, 1981, pp. 35-45. La donación original en: ACC, Necrologio-Obituario, ff. 44v-45r.

${ }^{81}$ ACC, Obras Pías, leg. 315, exp. 2/1. 
con figuras, dos poyaletes de ras, seis almohadas de ras con figuras, y dos ballestas de cuerno de Alemania con dos armaduras y dos aljabas que deberían venderse para comprar ornamentos litúrgicos. Finalmente, donó también varios bienes raíces: como compensación de distribuciones mal ganadas, una viña en la aldea de Cólliga, de unas veinticinco peonadas, cuyo usufructo tenía el maestrescuela Álvaro de Jarava ${ }^{82}$; y para el Arca de la Limosna y el hospital dependientes del cabildo, una casa con heredad en Embid, de unas cuatro o cinco yugadas de extensión, y con dos bueyes ${ }^{83}$.

Según se ha dicho, con diez mil maravedís, otros mil anuales que el chantre donaría en vida, y con lo obtenido de la venta de algunos libros repetidos el cabildo catedralicio debería comprar, tras la muerte de Nuño Álvarez, una propiedad con cuyas rentas se financiaría la celebración de cinco aniversarios perpetuos: los tres primeros por las almas del cardenal Gil de Albornoz -fundador del colegio de San Clemente en Bolonia-, del obispo Álvaro de Isorna y de Pedro Arias Bahamonde, obispo de Mondoñedo, debiendo realizarse en las ochavas de la Epifanía; y otros dos por las almas de sus padres y por la del propio chantre, que se celebrarían durante los días trece al quince de julio de cada año ${ }^{84}$. Estos aniversarios, en definitiva, constituían un agradecimiento postrero hacia aquellas personas que más le habían favorecido a lo largo de su vida, y quizá no sea casual que su fundación por el chantre se produjese justo un año después del fallecimiento de los obispos Álvaro de Isorna y Pedro Arias Bahamonde, muertos ambos en $1449^{85}$.

De la documentación que ha llegado hasta nosotros se pueden extraer algunos datos acerca del nivel de vida del chantre, que al menos en ciertos aspectos se correspondía con el de la oligarquía y alta jerarquía eclesiástica de la ciudad. Parece que vivió muchos años, hasta su muerte, en una casa muy próxima a la catedral, casi adosada a su edificio, cerca de la torre de las campanas ${ }^{86}$, y ello a pesar de que en algún momento el cabildo intentó que se trasladase a vivir a una casa nueva cerca de

${ }^{82}$ Recordemos, según se dijo páginas atrás, que este Álvaro de Jarava se había incorporado en 1433 al concilio de Basilea, un año antes que Nuño Álvarez.

83 ACC, Necrologio-Obituario, ff. 44v-45r.

84 Ibídem, f. 45r. En la documentación catedralicia ha quedado constancia de la celebración de dichos aniversarios tras la muerte del chantre. Así, por ejemplo, en el libro de pitancería de 1477, que también abarca algunos años posteriores, se señala que el lunes 3 de enero de 1480 hubo procesión de finados y se celebraron los aniversarios por el alma del cardenal Gil de Albornoz y de los otros bienhechores del chantre Nuño Álvarez, según éste había dejado encargado al cabildo, donando para ello sus libros y otros bienes. ACC, Pitancería, 1477, f. 189r-v.

85 EUBEL, C., Hierarchia..., vol. II, pp. 148 y 212.

${ }^{86}$ ACC, Obras Pías, leg. 315, exp. 3. Parece que el chantre se habría trasladado a vivir a dicha casa en una fecha muy próxima al año 1458, pues en una ordenanza municipal del 14 de abril de dicho año, sobre la distribución de los diferentes alimentos y mercancías en el mercado semanal que se celebraba en la plaza de Santa María, junto a la catedral, se señala, entre otras cosas, que las berceras y hortelanas se sitúen "desde la puerta de san Llorente fasta la otra puerta donde morava el chantre, las quales han de estar e estén en el suelo por manera que non suban arriba a las gradas", indicándose en otro lugar que el pescado fresco se venda "en el lugar donde está agora la casa del chantre", mientras que el "pescado remojado e seco ha de estar e se vender pegado a la torre las campanas de la eglesia mayor de Santa María”. De ello se deduce que el chantre Nuño Álvarez era un personaje bien conocido por todos en la ciudad de Cuenca. Archivo Municipal de Cuenca, Actas municipales, leg. 194, exp. 4, f. 43r. 
la iglesia San Pedro, en la parte más alta de la ciudad ${ }^{87}$. Por su testamento sabemos que tenía a su servicio varias amas y criados; de estos últimos, concretamente, se cita a Pedro de Sanabria, vecino de Millana; a Juan de Ocaña; a Juan Sánchez Cachero y Diego de Aranda, vecinos de Cuenca; a Alfonso Terçeado; y a un tal Montenegro ${ }^{88}$. El primer biógrafo del chantre también menciona a un camarero y un mayordomo a su servicio ${ }^{89}$. Respecto a sus familiares y parientes directos, en el testamento se hace una referencia, pero sin señalar sus nombres, a sus padres, ya fallecidos, por quienes encarga una memoria y aniversario. Además también menciona a sus hermanos Inés Álvarez y Pedro Álvarez, así como a sus sobrinos Diego Álvarez, Juan Álvarez y por supuesto Luis de Fuente Encalada, a quien nombraría su heredero universal y patrón de su capilla de San Miguel en la catedral. Junto a todos ellos, se menciona a más de una docena de personajes diversos allegados o familiares, en sentido amplio, del chantre, a quien éste deja alguna manda ${ }^{90}$. Según la primera biografía de Nuño Álvarez, algunos de sus familiares y criados procedían de su tierra de origen, del ámbito leonés y de Sanabria ${ }^{91}$, lo que también queda corroborado en el testamento ${ }^{92}$.

Junto a los enormemente valiosos libros, propiedades, dinero y bienes raíces que figuran en la ya aludida donación de 1450, los bienes patrimoniales y cantidades de dinero que asimismo aparecen en el testamento ofrecen una clara idea de que el chantre gozaba de una elevada posición económica, que trataría de hacer compatible con una vida pretendidamente humilde y austera, según la imagen que de él nos presentan todos sus biógrafos ${ }^{93}$, y con el desempeño de múltiples obras de caridad y mecenazgo que precisamente vienen a ratificar la importante posición del personaje en el marco de la oligarquía eclesiástica local. Así, en agosto de 1476, año de su muerte, el chantre era propietario, además de la casa en que vivía junto a la catedral, de otras "casas nuevas que yo fise en el barrio de Sant Pedro", uno de los más nobles de la ciudad, así como de otros "tres pares de casas que yo compré en esta çibdad,

${ }^{87} \mathrm{Si}$ otorgamos veracidad a lo que, relatado en términos piadosos, nos dice el primer biógrafo del chantre, el cabildo quería derribar su casa para realizar ciertas obras de ampliación de la catedral, por lo que se le ofreció irse a vivir a una casa nueva cerca de San Pedro, pero, al lamentarse Nuño Álvarez de que ya no podría acudir al rezo de maitines ni de las otras horas con tanta asiduidad como antes dada la mayor lejanía de su nueva casa, el cabildo decidió finalmente que siguiese como hasta entonces viviendo en la misma casa junto a la catedral. ACC, Obras Pías, leg. 315, exp. 3. En todo caso dicha casa nueva junto a San Pedro sí que está documentada entre las posesiones del chantre al redactarse su testamento en 1476. ACC, Obras Pías, leg. 315, exp. $2 / 1$.

${ }^{88}$ ACC, Obras Pías, leg. 315, exp. 2/1.

${ }^{89}$ ACC, Obras Pías, leg. 315, exp. 3.

${ }^{90}$ ACC, Obras Pías, leg. 315, exp. 2/1. Este sobrino del chantre, Luis de Fuente Encalada, según ya hemos dicho, había llegado en 1454 al colegio de San Clemente de Bolonia para estudiar Teología, recomendado por su tío y por el obispo Barrientos, ejerciendo el cargo de rector durante los años 1458-1459 y 1461-1463. Parece que no residió habitualmente en Cuenca, pues el chantre en su testamento hace mención a unas casas nuevas que había mandado construir en el barrio de San Pedro, en las que podría habitar su sobrino "sy por ventura... quesiere vevir en esta çibdad".

${ }^{91}$ ACC, Obras Pías, leg. 315, exp. 3.

${ }^{92}$ En el testamento se cita, entre otros criados y familiares, al ya mencionado Pedro de Sanabria, a Gonzalo de Meira, a Fernando de Sanabria y a Bartolomé de León. ACC, Obras Pías, leg. 315, exp. 2/1.

${ }^{93}$ Son muy claras y elocuentes en este sentido las palabras de su primer biógrafo, que nos dice que Nuño Álvarez vivió "en la carne e fuera de la carne, e en el mundo e fuera del mundo, e poseyendo riquezas e sin ellas, e que fizo maravillosas cosas en su vyda...". ACC, Obras Pías, leg. 315, exp. 3. 
las dos pares que están juntas en la Zapatería e otras en varrio Sant Pedro". También tenía varias heredades en Belmontejo, Fuentes Claras y en Mohorte ${ }^{94}$. A ello había que añadir, además de los muchos libros que ya había donado al cabildo años atrás y de cuyo usufructo disfrutaba, al menos otros ocho libros de carácter litúrgico que dejó a la iglesia de San Bartolomé de Belmonte, a su capilla de San Miguel y al monasterio de Santa María de la Contemplación. En cuanto al dinero que tenía, la suma de todas las diferentes cantidades que legó a instituciones y personas diversas, tanto clérigos como laicos, arroja una cifra que ronda los 170.000 maravedís. Es interesante que en el testamento el chantre haga alusión a su "libro de cuentas", que utilizaba para el control del dinero que poseía y el que había prestado a diferentes personas ${ }^{95}$, mientras que su primer biógrafo nos dice que sus rentas las recibía un mayordomo que le daba cuenta dos veces por semana de lo que percibía y gastaba ${ }^{96}$. Pero es que, además de todos los libros, dinero, propiedades y bienes citados, es de suponer que al chantre todavía le quedaría un importante remanente de dinero y bienes patrimoniales diversos, pues tras realizar todas las mandas testamentarias establece que "de lo que quedare e fyncare dexo por mi heredero universal al dicho Luis de Fuente Encalada mi sobrino..."97. En definitiva, todos los datos ratifican que nos encontramos ante un personaje de alta posición socioeconómica que debe situarse en la cúspide de la jerarquía eclesiástica de la ciudad.

\section{LA BIBLIOTECA DEL CHANTRE ${ }^{98}$}

El conocimiento de los libros y las bibliotecas en los reinos hispánicos medievales constituye una parcela historiográfica, afín a la denominada "Nueva Historia cultural", que en las últimas décadas ha experimentado sin duda enormes avances ${ }^{99}$, situándose ello en el contexto de una cierta revalorización del peso que la comuni-

${ }^{94}$ Se conserva la carta de venta fechada el 19 de junio de 1476, dos meses antes de la muerte del chantre, mediante la cual éste compró a Juan de Valenzuela, vecino de Cuenca, dos yuntas de heredad, un herrenal y un solar con casas en la aldea de Mohorte, al precio de 15.000 maravedís. ACC, Obras Pías, leg. 315, exp. 11.

95 ACC, Obras Pías, leg. 315, exp. 2/1.

96 ACC, Obras Pías, leg. 315, exp. 3.

97 ACC, Obras Pías, leg. 315, exp. 2/1.

98 Un reciente estudio global sobre la biblioteca de la catedral conquense durante la Edad Media, que también incluye un análisis de la biblioteca particular del chantre Nuño Álvarez, es el realizado por CHACÓN GÓMEZ-MONEDERO, F. A., "La biblioteca medieval de la catedral de Cuenca. Ubicación y reconstrucción bibliográfica", Bulletin Hispanique, 108/1 (2006), pp. 7-66.

99 Algo que facilitó mucho este progreso en el conocimiento de los libros y las bibliotecas fue la puesta a disposición de los investigadores de un amplio catálogo de fuentes disponibles para su estudio por FAULHABER, Ch., Libros y bibliotecas en la España medieval: una bibliografia de fuentes impresas, Londres, 1987. Asímismo hay que destacar la publicación de MARTÍN ABAD, J., Manuscritos de España. Guía de catálogos impresos, Madrid, 1997. Como obra de síntesis sobre el tema, aunque centrada sobre todo en las bibliotecas laicas bajomedievales, es imprescindible hacer referencia al trabajo de BECEIRO PITA, I., Libros, lectores y bibliotecas en la España medieval, Murcia, 2007. Respecto a la alta y plena Edad Media es fundamental, entre otros, el trabajo de ZIMMERMANN, M., Écrire et lire en Catalogne (IXe-XIIe siècle), 2 vols., Madrid, 2003. 
cación escrita, junto a la oral, tuvo en las sociedades medievales ${ }^{100}$. Dentro de este marco historiográfico, el estudio de las bibliotecas del clero y las catedralicias en particular ha contado con su propio desarrollo, tanto a nivel europeo como en España, debiendo destacarse en este último punto, sobre todo, el excelente y amplio trabajo de Susana Guijarro González sobre la formación cultural-académica y los libros del clero y las bibliotecas de las catedrales castellano-leonesas durante la plena y baja Edad Media ${ }^{101}$, a lo que habría que añadir otros muchos estudios y monografías particulares de diferente alcance y contenido ${ }^{102}$.

Según se recoge en el mencionado trabajo de Susana Guijarro, durante el siglo XV se observa en muchas catedrales castellanas, junto a un enorme enriquecimiento de sus bibliotecas, un considerable aumento, constatado estadísticamente, de los canónigos y dignidades que tenían algún tipo de titulación universitaria, sobre todo en Derecho canónico, siendo destacable también el notable aumento en el número de doctores con respecto a la centuria anterior ${ }^{103}$. Junto a los obispos, muchos de estos canónigos y dignidades aparecen en algún momento mencionados en la documentación como poseedores de libros diversos que frecuentemente legaban a la institución capitular a la que pertenecían, y el chantre Nuño Álvarez, doctor en Derecho canónico, constituye un claro ejemplo al respecto.

Aunque fueron muchos los miembros del cabildo catedralicio conquense que donaron a este último libros diversos, casi siempre a cambio de la celebración de aniversarios, sin embargo el legado bibliográfico más importante fue el realizado por Nuño Álvarez en la ya mencionada donación de marzo de 1450. La aceptación por el cabildo de esta donación bibliográfica quedó recogida, concretamente, en la sesión capitular del 18 de marzo de dicho año. El chantre conservó en vida el usufructo de los libros, estableciendo además que su biblioteca tuviese un uso público "para que puedan estudiar los que non tovieren libros e veer las materias que quisieren veer, ansí clérigos commo legos, e que non puedan ser sacados los dichos libros de la dicha librería". También prohibió al cabildo la venta de cualquiera de sus libros, con excepción de los que ya estuviesen repetidos en la biblioteca capitular, que sí que podrían venderse. Unos años más tarde, en marzo de 1458, a solicitud del propio chantre, el cabildo flexibilizó la salida de estos libros de la biblioteca capitular, "aunque estoviesen con cadenas ligados", cuando fuera el donante quien los solicitaba, si bien dejando clara constancia de que los libros eran de propiedad capitular y a su biblioteca debían retornar. Con todo, sabemos que Nuño Alvarez no entregó al cabildo de una vez la totalidad de los libros objeto de esta donación, pues en un acta capitular de

${ }^{100}$ Véase al respecto el trabajo de SAENGER, P., "Silent reading: its impact on late Medieval script and society", Viator, 13 (1982), pp. 367-414.

${ }^{101}$ GUIJARRO GONZÁLEZ, S., Maestros, escuelas y libros. El universo cultural de las catedrales en la Castilla medieval (Biblioteca del Instituto Antonio de Nebrija, $\mathrm{n}^{\circ}$ 14), Madrid, 2004. El trabajo está centrado en las catedrales de Astorga, León, Salamanca, Zamora, Segovia, Ávila, Burgo de Osma, Palencia y la iglesia colegial de Valladolid, y a partir de inventarios y referencias diversas se recogen, en un anexo final, casi 2000 menciones de libros medievales para el conjunto de catedrales estudiadas.

102 Tan sólo citaré, por su especial relieve, el de GONZÁLVEZ RUIZ, R., Hombres y libros de Toledo (1086-1300), Madrid, 1997.

${ }^{103}$ GUIJARRO GONZÁLEZ, S., Maestros, escuelas y libros..., pp. 97, 111 y 114. 
abril de 1458 se deja noticia de la entrega por el chantre en ese momento de doce de los libros que había donado ${ }^{104}$.

Años después, en su testamento de agosto de 1476, el chantre ratificaría esta donación al cabildo de "todos mis libros que tengo en latyin". Asimismo, también ratificó la donación que había hecho en 1450, para después de su muerte, de diez mil maravedís, estableciendo que con ellos y con lo que se sacara de la venta de los libros "que non fueren menester para la librería" se comprara una posesión para pagar con sus rentas los cinco aniversarios perpetuos de cuya celebración debía encargarse el cabildo, según ya se dijo páginas atrás. Más concretamente, el chantre explicitó que "los libros que se han de vender son el Decreto e Decretales, que son muy verdaderas aunque non son fermosas, e las Clementynas e el Sexto que fue de la iglesia e dí otro por él porque era fermoso, el qual el cabildo vendió al prior de Uclés para un su sobryno, e si otros lybros tovieren que non sean menester para la librería véndanse para comprar la posesión para los dichos adniversarios"; ello, en definitiva, nos ofrece una clara idea del enorme valor económico que los libros manuscritos tenían en la época, pues de la venta de unos pocos podían llegar a obtenerse cantidades significativas de dinero con las que hacer frente a la compra de bienes raíces. Además, Nuño Álvarez en su testamento mandó también al cabildo que permitiesen al bachiller Pedro Jiménez Zomeño, cura de Montalbanejo, por ser "buen letrado", sacar los libros de la biblioteca capitular y tenerlos en su casa de Cuenca para estudiarlos, siempre que así lo desease, con el compromiso de devolverlos a la biblioteca ${ }^{105}$.

Según se ha señalado con anterioridad, la biblioteca particular que el chantre donó al cabildo en 1450 ha sido ya objeto de sendos estudios que recogen básicamente la identificación de las obras que la formaban ${ }^{106}$. No obstante, este trabajo quedaría incompleto sin incluir en el mismo una relación y breve valoración personal e interpretación global de la serie de libros que formaban dicha biblioteca, que eran los siguientes ${ }^{107}$ :

-Un Decreto (Corpus Iuris Canonici, Decretum).

-Unas Decretales (Corpus Iuris Canonici, Decretales).

-Un Sexto (Corpus Iuris Canonici, Sextus liber Decretalium).

-Unas Clementinas (Corpus Iuris Canonici, Clementinae seu Septimus liber Decretalium).

${ }^{104}$ CHACÓN GÓMEZ-MONEDERO, F. A., "La biblioteca medieval de la catedral de Cuenca...", pp. 32-33.

${ }^{105}$ ACC, Obras Pías, leg. 315, exp. 2/1.

106 TRENCHS ODENA, J., "La cultura jurídico-piadosa del cabildo conquense...”, pp. 35-45; CHACÓN GÓMEZ-MONEDERO, F. A., "La biblioteca medieval de la catedral de Cuenca...", en particular pp. 31-35 y $50-64$.

107 Recojo los libros que el chantre donó al cabildo según aparecen en el mencionado trabajo de CHACÓN GÓMEZ-MONEDERO, F. A., "La biblioteca medieval de la catedral de Cuenca...", pp. 33-35, y 50-64 identificando los libros. La identificación de las obras va entre paréntesis. Este autor transcribe el listado de libros del chantre según aparece en el acta capitular que recoge la sesión del 18 de marzo de 1450, incorporando también algunos libros que no están en dicha acta pero que sí que recogía el profesor José Trenchs en su anterior análisis de la biblioteca del chantre. 
-Iohanes de Fantucis, sobre Doze causas del Decreto (Iohannes de Fantuciis, quizá sus Commentarii Decretum).

-Un Código (Corpus Iuris Civilis, Codex).

-Un Digesto viejo (Corpus Iuris Civilis, Digestum vetus).

-Un Digesto nuevo (Corpus Iuris Civilis, Digestum novum).

-Un Volumen (Corpus Iuris Civilis, Volumen).

-Un Esforçado (Corpus Iuris Civilis, Infortiatum).

-Un Ignosçençio (Innocentius IV, Apparatus super quinque libris Decretalium).

-Un Speculo (Guillelmus Durandi, Speculum iuris).

-Unas Adiçiones del Especulo (Guillelmus Durandi, Speculum iuris cum additionibus).

-Dos volúmenes de miçer Dominico sobre el Sexto (Dominicus de Sancto Geminiano, Apparatus super Sexto).

-Dos volúmenes, repetidos, de Juan de Ymola sobre las Clementinas (Iohannes de Imola, Super Clementinis).

-La primera parte de miçer Anthonio sobre el Primero de las Decretales (Antonius de Butrio, Super prima parte primi Decretalium).

-Dos volúmenes de miçer Anthonio sobre el Segundo de las Decretales (Antonius de Butrio, Super secundam Decretalium).

-Un volumen de miçer Anthonio sobre el Terçero de las Decretales (Antonius de Butrio, Super tertium Decretalium).

-Un volumen de miçer Anthonio sobre el Quarto e Quinto de las Decretales (Antonius de Butrio, Super quartum et quintum Decretalium).

-Un volumen de miçer Palormithano sobre el Primero de las Decretales (Nicolaus Tudeschis, abad panormitanus, Lectura super primum librum Decretalium).

-Dos volúmenes de miçer Palormithano sobre el Segundo de las Decretales (Nicolaus Tudeschis, Lectura super secundum librum Decretalium).

-Un volumen de miçer Palormithano sobre el Terçero de las Decretales (Nicolaus Tudeschis, Lectura super tertium librum Decretalium).

-Un volumen de miçer Palormithano sobre el Quarto e el Quinto (Nicolaus Tudeschis, Lectura super quartum et quintum librum Decretalium).

-Un volumen de Iohanes de Ymola sobre el Primero de las Decretales (Iohannes de Imola, Lectura in primum librum Decretalium).

-Dos volúmenes de Iohanes de Ymola sobre el Terçero (Iohannes de Imola, Lectura in tertium librum Decretalium).

-Una Suma de Azon (Azzo de Bolonia, Summa super Codicem).

-Un volumen de Álvaro Yspano, episcopu coronensis, De statu et plantu ecclesie (Alvarus Hispanus -Álvaro Pelayo-, De statu et planctu Ecclesiae).

-Un Repertorio de Calderino (Iohannes Calderinus, Repertorium iuris).

-Un libro sobre ciertos tratados De potestate concilii (Obra de identificación imprecisa. Podría ser Petrus de Monte Brixiensis, De potestate romani pontificis et generali concilii; o Nicolaus Tudeschis, De auctoritate pape, concilii et cardinalium; o incluso quizá Juan de Segovia, Tractatus de potestate ecclesiae et auctoritate conciliorum). 
-Un volumen de Petro Boneti sobre las Decretales (Petrus Boneti, Lectura super Decretales).

-Un volumen con los tratados De laudibis Virginis, De preceptis y De compendio theologice veritatis (Raymundus Lullus, De laudibus Virginis Mariae; Thomas de Aquino, De decem praeceptis; Hugo Ripelin, De compendium theologicae veritatis).

-Un volumen con las Diçisiones de Rueda por cotas, con ciertos Tractados (Guillelmus Horborgh, Decisiones Rotae Romanae; unos Tratados sin identificar).

-Un libro con las Diçisiones de Rueda por títulos, con otros Tractados (Guillelmus Horborgh, Decisiones Rotae Romanae; unos Tratados sin identificar).

-Un libro De oculo moral (Petrus de Limoges, De oculo morali).

-Un libro De dilecione proximi (Bernardus de Claraval, De dilectione proximi).

-Un libro De vilitate humane condicionis (Innocentius III, De vilitate conditionis humanae).

-Decreta Concilii Basiliensis cum aliis actibus aliquorum (de los Decretos del Concilio de Basilea se conservan copias manuscritas del siglo XV en numerosos códices).

-Un libro con algunos Sermones (ciertos Sermones de identificación imprecisa, quizá copia del Ms. 54 del Colegio de España en Bolonia).

Realizando una valoración general del contenido de esta biblioteca personal que el chantre donó al cabildo catedralicio, hay que destacar ante todo el claro predominio (unas dos terceras partes) de las obras de Derecho canónico -sobre todo del Corpus Iuris Canonici y sus principales comentaristas hasta el momento-, tratándose sin duda de libros que adquirió o mandó copiar durante su estancia en el colegio de San Clemente, en Bolonia, o quizá también mientras estuvo en el concilio de Basilea. Siguen en importancia, en número inferior, las obras de Derecho civil, mientras que en un último grupo de carácter misceláneo se integrarían varios libros de contenido teológico, moral o litúrgico.

En cuanto al predominio de los libros de Derecho canónico, se trata de algo que queda plenamente justificado por la formación académica del chantre en esta disciplina, representada también mayoritariamente, durante los siglos XIV y XV, en muchas bibliotecas catedralicias castellano-leonesas ${ }^{108}$. Así, del Corpus Iuris Canonici, en la biblioteca de Nuño Álvarez están presentes el Decreto de Graciano (c. 1143), las Decretales de Gregorio IX (1234), el Sexto de Bonifacio VIII (1298) y las Clementinas de Clemente V (1305), junto a las obras de sus principales comentaristas: Juan de Fantucis para el Decreto; Niccolò Tedeschi -abad Panormitano- (1386-1445), Antonio de Butrio (c. 1338-1408), Juan de Imola (c. 1370-1436), Pedro Boneti e Inocencio IV, para las Decretales; de nuevo Juan de Imola, para las Clementinas; y Domingo de San Geminiano (c. 1375-1424) ${ }^{109}$, para el Sexto. Estos comentarios al Decreto y

108 GUIJARRO GONZÁLEZ, S., Maestros, escuelas y libros..., p. 129.

109 Un análisis sobre estos dos últimos autores y sus posturas durante el Cisma y la crisis conciliar es el de CABLE, M. J., The "obediences" of the Great Schism and conciliar era: the distinction between the personal and territorial with jurists Johannes de Imola, Dominicus de Sancto Geminiano and Petrus de Monte, Londres, 2001. 
sobre todo a las Decretales -los más abundantes-, también presentes con frecuencia en las bibliotecas de otras catedrales castellano-leonesas, pertenecían a dos géneros jurídicos ampliamente desarrollados en las universidades medievales, esto es, el casus o introducción a cada ley, capítulo y párrafo que resume el texto, y las glossae o comentarios cortos de un texto legal ${ }^{110}$.

Particularmente interesante es la presencia en la biblioteca del chantre de los comentarios de las Decretales realizados por el canonista Nicolaus Tudeschis -Niccolò Tedeschi-, conocido vulgarmente como el abad Panormitano (1386-1445), no sólo por tratarse de uno de los comentaristas más célebres del momento, sino porque es incluso muy posible que Nuño Álvarez le hubiese conocido personalmente en algún momento durante su permanencia en el concilio de Basilea. Niccolò Tedeschi había nacido en Catania, en Sicilia, entrando en la orden benedictina hacia 1400. Tras estudiar Derecho canónico, lo enseñó con gran reputación en Bolonia, Parma, Siena y Florencia, y en 1435 se convirtió en abad de Palermo: de ahí el nombre de Panormitanus con el que se le conocía. En 1433 Eugenio IV le había enviado al concilio de Basilea para defender los intereses pontificios, pero desde 1436 pasó a mostrarse partidario de la superioridad del concilio general sobre el papa, llegando incluso a apoyar al antipapa Félix V, que le nombró cardenal, y sólo muy tardíamente, cuando la causa conciliarista estaba perdida, retornó a la obediencia pontificia ${ }^{111}$.

Otro autor destacado en la biblioteca del chantre es el canonista Guillermo Durand (c. 1230-1296), con su Speculum iuris y su Speculum iuris cum additionibus. Nacido en Francia, enseñó en Módena y posiblemente también en Bolonia, donde había estudiado, participando activamente en las sesiones del II Concilio de Lyon de 1274. Su obra jurídica más conocida, de gran difusión posterior, fue el Speculum iuris, que haría que su autor adquiriese el sobrenombre de "Speculator" 112 . Y, asimismo, otro canonista que figura entre los libros del chantre es Juan Calderinus, con su Repertorium (sive dictionarium) iuris. Calderinus, que se había doctorado en Derecho canónico en Bolonia en 1326, enseñaría en esta universidad al menos hasta 1359, muriendo seis años más tarde; sus numerosos escritos jurídicos, además de comentarios a algunas obras del Corpus Iuris Canonici, también abarcaron otros géneros: tractatus, con-

110 GUIJARRO GONZÁLEZ, S., Maestros, escuelas y libros..., p. 183.

111 CROSS, F. L.; LIVINGSTONE, E. A. (dirs.), The Oxford Dictionary of the Christian Church, Oxford, 1997, p. 1214. Un estudio fundamental sobre este célebre canonista y su papel en el concilio de Basilea es el de VAGEDES, A., Das Konzil über dem Papst? Die Stellungnahmen des Nikolaus von Kues und des Panormitanus zum Streit zwischen dem Konzil von Basel und Eugen IV, 2 vols., Paderborner Theologische Studien, 11, 1981. Véase también CONDORELLI, O. (dir.), Niccolò Tedeschi (Abbas Panormitanus) e i suoi Commentaria in Decretales, Roma, 2000. Los comentarios y obras jurídicas del abad Panormitano alcanzaron tal difusión en el siglo XV que incluso fueron a su vez objeto de estudio y comentario por parte de otros juristas: buena prueba de ello es el Repertorium operum panormitani de Alfonso Díaz de Montalvo, que en 1496 figuraba entre los numerosos libros propiedad del obispo de Burgos, Luis de Acuña. GUIJARRO GONZÁLEZ, S., Maestros, escuelas y libros..., p. 226, y Anexo, reg. 1386.

112 CROSS, F. L.; LIVINGSTONE, E. A. (dirs.), The Oxford Dictionary of the Christian Church, p. 517. Sobre esta obra puede verse el reciente trabajo de CONETTI, M., "La funzione politica del giudice nello Speculum iuris di Guillaume Durand", en RIGON, A., y VERONESE, F. (dirs.), L'età dei processi. Inchieste e condanne trà politica e ideologia nel'300, Roma, 2009, pp. 81-118. Sobre Guillermo Durand y el conjunto de su obra hay que destacar el trabajo colectivo de GY, P. M. (dir.), Guillamume Durand, evêque de Mende (v. 1230-1296). Canoniste, liturgiste et homme politique, París, 1992. 
silia, arengae y repertorium, del que su mencionado Repertorium iuris constituye un buen ejemplo de obra escolar, recogiendo un listado alfabético de términos clave tanto de Derecho canónico como romano ${ }^{113}$.

El posible interés de Nuño Álvarez por los temas relacionados con la discusión y la polémica eclesiástica vendría dado por la presencia entre sus libros de la obra del importante canonista, franciscano y escotista Álvaro Pelayo -o Álvaro Hispano- (c. 1280-1349) De statu et planctu Ecclesiae, donde, a la vez que se defiende con firmeza la doctrina teocrática, también se critican duramente los vicios y abusos de la Iglesia, como eran la simonía, el absentismo y el concubinato clerical, y el fausto desmedido de la corte pontificia ${ }^{114}$.

Por otro lado, la participación activa de Nuño Álvarez en el concilio de Basilea explica sin duda que entre los manuscritos de su biblioteca se encuentre también una copia de los Decreta Concilii Basiliensis cum aliis actibus aliquorum, así como del tratado de difícil identificación De potestate concilii, si bien Nuño Álvarez, en sintonía con el obispo Álvaro de Isorna, nunca llegó a ser un firme partidario de las ideas conciliaristas $^{115}$.

En cuanto a los libros de Derecho civil que tenía Nuño Álvarez, menos numerosos, destacan principalmente los que formaban parte del Corpus Iuris Civilis, que es la elaboración medieval de la legislación bajoimperial de Justiniano: Codex, Digestum vetus, Digestum novum, Volumen e Infortiatum. Entre los varios comentaristas de estas obras únicamente tenemos la presencia de Azzo de Bolonia, con su Summa super Codicem, libro de gran peso en la enseñanza del Derecho civil durante la baja Edad Media, que por lo demás también aparece entre los libros que poseyeron otros personajes de la alta jerarquía eclesiástica castellana ${ }^{116}$.

Por último tendríamos los libros de contenido teológico, moral o litúrgico, que, aunque abundaban en las bibliotecas catedralicias castellano-leonesas ${ }^{117}$, estaban algo menos representados en la del chantre Nuño Álvarez. En este grupo hay que situar los libros de Raimundo Llull, De laudibus Virginis Mariae; Tomás de Aquino, De

113 CLAES, D., “Adam per Evam deceptus est, non Eva per Adam. Biblical Repertoria in Fourteenth Century Canon Law”, en ROEST, B. y VANSTIPHOUT, H. (eds.), Aspects of Genre and Type in Pre-Modern Literary Cultures, Groningen, 1999, p. 5, nota 25. Sobre el pensamiento jurídico de Calderinus puede destacarse el reciente trabajo de BELLOMO, M., "La logica del filosofo e la logica del giurista. Giovanni Calderini tra doctores antiqui, moderni e moderniores", Mélanges en l'honneur d'Anne Lefebvre-Teillard, París, 2009, pp. 123-134.

114 Sobre este autor, muy estudiado por la historiografía, hay que destacar entre otros el reciente trabajo de CARVALHO, M. A., Estudos sobre Álvaro Pais e outros franciscanos (seculos XIII-XV), Lisboa, 2001. Y sobre su obra mencionada véanse algunos nuevos puntos de vista en MORAIS BARBOSA, J., "Nuovi apporti alla storia redazionale del De statu et planctu ecclesiae di Alvaro Pelagio", Medioevo. Rivista di Storia della Filosofia Medievale, 15 (1989), pp. 315-324.

115 Un estudio general acerca de los autores de origen hispano que fueron más afines al conciliarismo se encuentra recogido en el trabajo de GOÑI GAZTAMABIDE, J., "El conciliarismo en España", Scripta Theologica, 10 (1978), pp. 893-928.

116 Por ejemplo, el maestro Pedro, chantre de la catedral de Salamanca, en 1240; Rodrigo Pérez, arcediano de León, en 1268; el arcediano de Burgos, en 1277; o el obispo de Burgos, Luis de Acuña, en 1496. GUIJARRO GONZÁlEZ, S., Maestros, escuelas y libros..., Anexo, nº 179, 526, 831 y 1366. Vid. también VIORA, M. (dir.), Corpus glossatorum iuris civilis. Azonis lectura super codicem, Turín, 1966.

117 GUIJARRO GONZÁLEZ, S., Maestros, escuelas y libros..., p. 168. 
decem praeceptis; Hugo Ripelin de Estrasburgo, De compendium theologicae veritatis $^{118}$; Pedro de Limoges, De oculo morali ${ }^{119}$; Bernardo de Claraval, De dilectione proximi ${ }^{120}$; Inocencio III, De vilitate conditionis humanae ${ }^{121}$; así como una obra de identificación imprecisa, ciertos sermones, género limítrofe entre la teología y la liturgia, pues frecuentemente los sermones se recopilaban en sermonarios de clara funcionalidad litúrgica.

No obstante en el año de su muerte, 1476, según se contiene en su testamento, encontraremos al chantre en posesión de al menos otros ocho libros más de contenido esencialmente litúrgico, que serán objeto de donaciones diversas: un misal nuevo para las monjas benedictinas del monasterio conquense de Santa María de la Contemplación, por él fundado, para el servicio del altar; una biblia y "el raçional que fise escrivir en papel e el libro pobre e otro libro que se llama manípulo escolastorum", para la iglesia colegial de San Bartolomé de Belmonte, cuyo prior los tendría en depósito hasta que finalizasen las obras de dicha iglesia, en cuya sacristía debían permanecer atados con cadenas para su libre lectura, no pudiendo venderse ni enagenarse ni sacarse fuera de la iglesia ${ }^{122}$; cierto breviario que había tenido antes el difunto canónigo Pedro Suárez, que debía venderse para comprar una posesión con

118 Sobre esta obra véase: MICHLER, C. (ed.), Le somme abregiet de theologie: die altfranzösische Übersetzung des "Compendium theologicae veritatis" Hugo Ripelins von Strasburg, Wiesbaden, 1996.

119 Un muy reciente estudio sobre este libro, con su traducción al inglés, es el de NEWHAUSER, R. G., The moral treatise on the eye. Peter of Limoges, Toronto, 2012. Véase asimismo el trabajo de SCHLEUSENEREICHHOLZ, G., "Naturwissenschaft und Allegorese: der Tractatus de oculo morali des Petrus von Limoges", Frühmittelalterliche Studien, 12 (1978), pp. 258-309.

${ }^{120}$ Una prueba de la importante estima que tenía Nuño Álvarez hacia el pensamiento religioso de san Bernardo viene dada por el hecho de que este último aparece citado al comienzo de su testamento. ACC, Obras Pías, leg. 315, exp. 2/1.

121 Ed. LEWIS, R. E., De miseria condicionis humane. Lothario dei Segni (Pope Innocent III), Atenas, 1978.

122 El prior de Belmonte, que también es citado como canónigo de Cuenca, era sin duda persona muy próxima al chantre, pues en 1476 éste le designaría como su testamentario, junto a varias personas más. ACC, Obras Pías, leg. 315, exp. 2/1. Se trataba de Fernando Sánchez de Cuenca, un clérigo instruido, bachiller en Leyes, que fue el primero en ejercer este cargo, y que frecuentemente estuvo ausente de la villa de Belmonte a la vista de los sucesivos tenientes de prior que le sustituyeron, falleciendo en 1482. AYLLÓN GUTIÉRREZ, C., "Iglesia y poder en el marquesado de Villena. Los orígenes de la colegiata de Belmonte", Hispania Sacra, LX/121 (2008), p. 107. En febrero de 1476, año de la muerte del chantre, nos encontramos con una noticia de que el prior de Belmonte tenía a censo unas casas del cabildo catedralicio en la "cal Mayor" de Cuenca, lo que viene a confirmar su residencia en la ciudad. ACC, Pitancería, 1476, f. 23v. Años atrás, el 1 de diciembre de 1459, y a petición del marqués de Villena Juan Pacheco, el papa Pío II había erigido en colegiata la antigua iglesia parroquial de san Bartolomé de Belmonte, que a partir de entonces, encabezada por un prior, tendría cantoría, tesorería, canonjías, raciones, préstamos, beneficios simples y capellanías. El subdelegado pontificio encargado de realizar la erección colegial fue el canónigo conquense Ruy Gómez de Anaya, contando para ello con la aprobación del obispo y cabildo catedralicio de Cuenca, otorgada el 4 de diciembre de 1460. ACC, Actas Capitulares de 1460, ff. 151r-152v. En adelante la nueva colegiata permanecería bajo el patronato de los marqueses de Villena. Tras la erección colegial Juan Pacheco costeó gran parte de las obras de mejora de la antigua parroquia, construyendo la capilla mayor de la iglesia, donde se colocarían los enterramientos de sus padres y abuelos; estas obras todavía no habían finalizado en 1476, cuando Nuño Álvarez hizo su testamento. El prestigio e importancia que a partir de entonces tendría esta nueva y única colegiata de la diócesis conquense contribuyen a explicar que el chantre, que ya había donado la mayor parte de su importante biblioteca al cabildo catedralicio, quisiera también mostrar su generosidad hacia la nueva institución colegial de la diócesis donando cuatro de sus libros. Sobre los momentos fundacionales de la colegiata de Belmonte 
cuyas rentas el cabildo tendría que celebrar una memoria anual por dicho canónigo; y otros dos breviarios más, "el uno de regla toledana e el otro de regla romana, de dos romanos que tengo el mejor", para su capilla de San Miguel en la catedral, donde deberían permanecer "fixos en la dicha mi capilla en la pared puestos, en sus rexas con sus cadenas, para en que puedan resar los capellanes que sirvieren la dicha mi capilla o otros qualesquier clérigos que quisieren, porque rueguen a Dios por mi ánima”. La mención que hace el chantre a estos dos breviarios, uno de regla "toledana" y otro de regla "romana", reviste un especial interés desde el punto de vista de la liturgia. Por un lado, el primer biógrafo del chantre nos dice que éste al parecer acostumbraba rezar cada día las horas canónicas alternando el uso de ambas reglas ${ }^{123}$, y por otra parte ello viene a ser una constatación de que en la iglesia de Cuenca, junto a la regla estrictamente romana o latina, la llamada "regla toledana" era ampliamente utilizada ${ }^{124}$, pues, tal y como se recoge en la legislación sinodal del siglo XV, la iglesia conquense debía en teoría seguir las normas de la metropolitana de Toledo, de la que dependía, en la celebración de muchas festividades litúrgicas ${ }^{125}$. Asimismo hay que poner también de relieve la alusión que se hace en el testamento a un tal Juan Sánchez, cura de Villar del Horno, a quien el chantre había entregado cierta cantidad de maravedís y unos pergaminos para que le escribiese un breviario ${ }^{126}$.

Finalmente hay que destacar que, por los mismos años en que el chantre Nuño Álvarez realizó la donación de libros al cabildo, también encontraremos a algún otro miembro destacado de la institución donando a esta última sus libros. Un ejemplo lo tenemos en el canónigo, deán y vicario general del obispado en varias ocasiones, Nicolás Martínez de la Campana; este personaje, que era bachiller en Decretos y que había sido también familiar del obispo Álvaro de Isorna ${ }^{127}$, aparece en 1455 como

puede verse el citado trabajo de AYLLÓN GUTIÉRREZ, C., "Iglesia y poder en el marquesado de Villena. Los orígenes de la colegiata de Belmonte", pp. 95-130.

${ }^{123}$ ACC, Obras Pías, leg. 315, exp. 3. Según su biógrafo conquense, el chantre rezaba según la regla romana por haber sido promovido a las órdenes que tenía en Roma, mientras que el uso de la toledana vendría dado por su frecuente utilización en la liturgia de la iglesia conquense.

${ }^{124}$ Desde fines del siglo XIII, con la llegada a la silla arzobispal toledana de algunos hombres pertenecientes a estirpes mozárabes de Toledo, como los Gudiel o los Palomeque, algunos elementos del rito mozárabe se incorporaron al romano. Así, los misales, breviarios, salterios y santorales pertenecían a la llamada "regla toledana", conteniendo las normas litúrgicas comunes junto con las variantes toledanas del rito romano, variantes numerosas que afectaban al calendario, a las festividades, al oficio de los santos, a las lecciones del oficio divino y, en general, a las costumbres litúrgicas locales. Ramón Gonzálvez, en su amplio estudio sobre los libros de la catedral de Toledo hasta 1300, recoge varios ejemplos de breviarios para el rezo de las horas adaptados a la regla toledana. GONZÁLVEZ RUIZ, R., Hombres y libros de Toledo, pp. 559, 652 y 687. Otras iglesias castellanas también podían tener sus propias costumbres litúrgicas. Así, entre los libros que había en la catedral de Toledo en el siglo XIII se encontraba un Breviario de Burgos, escrito según las peculiaridades litúrgicas de esta última iglesia. Ibídem, p. 215.

${ }^{125}$ Así se recoge, por ejemplo, en el sínodo del obispo Diego de Anaya de 1413, y en el de Lope de Barrientos de 1446. GARCÍA Y GARCÍA, A. (dir.), Synodicon Hispanum, vol. X, pp. 172-173, y 287-289. Por otro lado, en el Necrologio-Obituario de la catedral conquense hay una noticia sobre las festividades de los domingos de Ramos y de Pascua, de Pentecostés, del Corpus y de la Santísima Trinidad, y de sus octavas, que debían celebrarse de acuerdo con la regla toledana. ACC, Necrologio-Obituario, ff. 8v y 18r.

${ }^{126}$ ACC, Obras Pías, leg. 315, exp. 2/1.

127 Véase mi libro Iglesia, sociedad y poder..., p. 650. 
usufructuario de trece libros de Derecho que había donado al cabildo a cambio de dos $\operatorname{aniversarios}^{128}$.

\section{RELIGIOSIDAD Y EJERCICIO DE LA CARIDAD. LAS ACCIONES DE MECENAZGO}

Aparte del interés que revisten la trayectoria eclesiástica de Nuño Álvarez, su formación académica en Bolonia y el contenido de su biblioteca particular, probablemente la faceta más destacada de nuestro personaje sea la que viene dada por su singular espiritualidad, sus creencias religiosas y las actividades caritativas y de mecenazgo que llevó a cabo, siendo básicamente por esta faceta por la que tras su muerte se le recordaría en la iglesia de Cuenca, constituyéndose así un determinado tipo de memoria histórica en torno a su figura.

Por el testamento del chantre sabemos que su capellán y confesor en el momento de redactarse era Alfonso Sánchez de Huete, que junto a otros sería nombrado testamentario ${ }^{129}$. Según el primer biógrafo de Nuño Álvarez, antes su confesor había sido el canónigo Lorenzana -se refiere a Alfonso Rodríguez de Lorenzana- , que al fallecer en 1473 había dejado al Arca de la Limosna de la catedral como heredera universal ${ }^{130}$, y también cita como su confesor a cierto racionero "que llamavan Baeça" 131 , que no es otro que Francisco Martínez de Baeza, que sería testigo en el otorgamiento del testamento del chantre ${ }^{132}$.

Algo que destacan todos sus biógrafos es el estricto cumplimiento por parte del chantre de su obligación de acudir al rezo de las horas en el coro de la catedral, incluidos los maitines, lo que se veía favorecido por la proximidad de su casa a la catedral. Para este rezo de las horas canónicas al parecer alternaba el empleo de las reglas litúrgicas romana y toledana, algo constatado por su testamento y primera biografía, según ya se ha señalado. Junto a ello cobran un especial relieve su devoción mariana -la fundación por el chantre del monasterio de Santa María de la Contemplación constituye una buena prueba-, hacia San Lázaro, y muy en particular hacia el arcángel San Miguel, protector de las almas en el momento de la muerte, algo patente en la capilla que bajo su advocación mandó construir para su enterramiento en la catedral, y en la conmemoración especial que realizaba de las dos fiestas anuales en honor de este santo, en mayo y en septiembre ${ }^{133}$.

Su particular actitud caritativa y proteccionista hacia los niños "falladizos" que estaban "por criar", que también encontramos en otros eclesiásticos prominentes de

\footnotetext{
${ }^{128}$ CHACÓN GÓMEZ-MONEDERO, F. A., "La biblioteca medieval...,", p. 40.

${ }^{129}$ ACC, Obras Pías, leg. 315, exp. 2/1.

${ }^{130}$ ACC, Pitancería, 1473, f. 186r.

131 ACC, Obras Pías, leg. 315, exp. 3.

${ }^{132}$ ACC, Obras Pías, leg. 315, exp. 2/1.

${ }^{133} \mathrm{Su}$ anónimo biógrafo conquense también nos dice que "fizo escrivir un libro de los milagros de señor sant Miguel para leer cada día", si bien este libro no se cita para nada en el testamento del chantre. ACC, Obras Pías, leg. 315, exp. 3.
} 
la época ${ }^{134}$, quedó bien reflejada en su testamento de 1476 , donde establece que los "niños que están por criar que los críen a mi costa, e que después que los den a quien mis testamentarios quisieren", determinando también que, a su costa, se enviasen a sus dos hermanos y a sus dos sobrinos "sendos niños destos que él avía fecho criar, para que los críhen e fagan bien por serviçio de Dios e por amor suyo. E que al dicho Diego de Valera que le den una niña para que la críhe e la case, e a Alfonso Terçado su criado que le den a Calisto y a Tecla, para que los críe e los case por serviçio de Dios e por amor suyo, el qual dicho Alfonso Terçeado dixo que era contento e le plasía de lo faser". Asimismo manifestó que si cualquiera de sus demás criados quisiera hacerse cargo del cuidado de alguno de estos niños, que se lo diesen ${ }^{135}$. Por otro lado, su anónimo biógrafo conquense señala, sin duda de forma extremadamente exagerada, que el chantre hizo criar durante los años que estuvo en Cuenca a más de cuatrocientos de estos "niños falladizos", que los amos y amas que los criaban acudían con ellos un día a la semana al mercado principal que se celebraba en la plaza junto a la catedral y el chantre les daba a todos públicamente de $\operatorname{comer}^{136}$, y que a los niños les hacía aprender oficios diversos según las habilidades de cada uno, mientras que a las niñas las metía como novicias en el monasterio benedictino de Santa María de la Contemplación, cuya construcción había financiado él mismo, dedicándose también a casar huérfanas dándoles dotes suficientes ${ }^{137}$, algo esto último que corrobora el testamento. Todo este despliegue público de generosidad para criar y sacar adelante a estos niños hacía necesario contar con una muy sólida base económica, por lo que habría que preguntarse si al menos en algunos momentos el chantre, además de emplear sus rentas personales, también utilizó para ello las del cabildo y particularmente las del Arca de la Limosna, a favor de la cual había donado una heredad en 1450 y de la que también había sido limosnero en 1464.

Algunos años después de la muerte de Nuño Álvarez, su preocupación hacia estos niños "expósitos" o "falladizos" tendría continuación en una decisión tomada el 21 de marzo de 1488 por el cabildo catedralicio conquense, que en esta fecha cedió al canónigo Alonso Ruiz unas casas que eran llamadas "de las beatas" para que instalase en ellas en cierto plazo un hospital destinado a acoger a "los niños que fueren echados a la puerta de la yglesia por bautizar", dotándolo adecuadamente de rentas y poniendo a personas "de honesta vida que tengan cargo de resçebir las dichas criaturas e darlas a criar"138. Así, pues, con la creación en Cuenca de este particular hospital de carácter asistencial se pasaba de una cierta preocupación individual hacia el cuidado de estos niños "expósitos", como la manifestada años atrás por el chantre, a un intento de institucionalización de la atención a los mismos, tratándose de un problema que, en todo caso, pone en evidencia la grave situación de marginación y extrema precariedad eco-

${ }^{134} \mathrm{Tal}$ es el caso, por ejemplo, del nuncio Francisco Ortiz, que en 1483 recibió autorización del papa Sixto IV para fundar en Toledo, con cargo a sus muy saneados bienes, un hospital de funcionalidad mixta, bajo la advocación de la Visitación, para albergar treinta y tres dementes y trece niños expósitos. LOP OTÍN, M. J., El cabildo catedralicio de Toledo en el siglo XV, pp. 371-372.

${ }^{135}$ ACC, Obras Pías, leg. 315, exp. 2/1.

136 El biógrafo señala haber sido testigo directo de este agasajo a los niños "falladizos" el día del mercado semanal, celebrado en la plaza de Santa María o del Mercado junto a la cual tenía su casa el chantre.

${ }^{137}$ ACC, Obras Pías, leg. 315, exp. 3.

${ }^{138}$ ACC, caj. 5, leg. 19, $\mathrm{n}^{\circ} 265$. 
nómica existente en los sectores más desfavorecidos de la sociedad conquense, algunos de cuyos miembros no podían o no querían asumir el hacerse cargo del ciudado y crianza de sus hijos recién nacidos ${ }^{139}$, siendo este un asunto que indudablemente debe ponerse también en relación con el creciente desarrollo de la prostitución en Cuenca durante estos años ${ }^{140}$, resultado de la cual muchos niños fruto de estas relaciones carnales acabarían probablemente convirtiéndose en los desventurados "falladizos" que eran abandonados y quedaban al amparo de la protección eclesiástica.

Pero al parecer la labor caritativa y asistencial del chantre no se limitaba a los niños abandonados y huérfanos. Así, si otorgamos veracidad a su primer biógrafo, también daba frecuentes limosnas y alimentos a los pobres vergonzantes y enfermos que vivían en las distintas parroquias de la ciudad ${ }^{141}$, acudía a los hospitales -especialmente al de San Lázaro, situado extramuros ${ }^{142}$ a entregar limosnas de su propia mano, repartía en ocasiones la pitanza que cobraba por asistir al rezo de las horas entre los pobres que pedían en la puerta de la catedral, e incluso en determinadas festividades señaladas daba de comer y lavaba los pies a un grupo de trece pobres ${ }^{143}$, como referencia simbólica al colegio apostólico ${ }^{144}$, actividad esta última que, de ser cierta, es posible que el chantre llevase a cabo con el apoyo económico del cabildo catedralicio y el Arca de la Limosna, inspirándose en similares comedores benéficos para trece indigentes que existían en la iglesia de Toledo, bajo el patrocinio de la mitra y del cabildo catedralicio ${ }^{145}$. No obstante, el biógrafo hace recaer exclusivamente

139 En otros lugares de Castilla también se crearon este tipo de hospitales para niños expósitos. Ejemplo de ello son uno que se encontraba anejo a la catedral de Salamanca, el hospital de Santo Tomé de Astorga, o la llamada "capellanía de los enechados" de Zamora. LÓPEZ ALONSO, C., La pobreza en la España medieval, Madrid, 1986, p. 418. Y poco después de que se decidiese crear el hospital de Cuenca, concretamente en abril de 1491, el cabildo catedralicio de Toledo también fundó y dotó una institución similar para hacerse cargo de los "niños e niñas que se echan en la piedra". LOP OTÍN, M. J., El cabildo catedralicio de Toledo en el siglo $X V$, p. 375 .

140 Está constatada la práctica de la prostitución en mancebías y en algunos mesones, fundamentalmente en los arrabales extramuros de la ciudad. Para más información véase el libro de SÁNCHEZ BENITO, J. M., El espacio urbano de Cuenca en el siglo XV, Cuenca, 1997, pp. 119-123.

${ }^{141}$ El biógrafo señala que el chantre también "fazía otras lymosnas secretas a los pobres que no salían de sus casas por enfermedades o por verguença de las gentes que los avían conosçido, e por todas las parrochyas de la çibdad fazía pesquisa quién heran estos pobres, e por çierta ynformaçión de los curas dellas tenía un libro o quaderno en el qual estavan escriptos estos tales pobres, e en seyendo anocheçido en estas vygilyas, mayormente con mucho secreto, fazía llevar lymosnas a sus casas, a cada uno tres panes e medyo açumbre de vino e medya libra de carnero, e çinco maravedís en dyneros”. ACC, Obras Pías, leg. 315, exp. 3.

142 En Toledo también había un hospital de San Lázaro, extramuros de la ciudad. Este tipo de hospitales generalmente atendían a pobres y personas afectadas por enfermedades infecto-contagiosas, como lepra, tiña o sarna, y de ahí su apartada localización. LOP OTÍN, M. J., El cabildo catedralicio de Toledo en el siglo XV, p. 370 .

143 ACC, Obras Pías, leg. 315, exp. 3.

144 Juan, 13:5-14.

145 En 1330 el arzobispo toledano Juan de Aragón había instituido y dotado un comedor benéfico para trece indigentes, que se situaba frente a la catedral, alcanzando un importante grado de popularidad en la ciudad hasta el siglo XVI. En abril de 1472 el cabildo catedralicio de Toledo dotó con rentas capitulares otro comedor similar para menesterosos, acordando que se diese de comer diariamente a trece pobres "a honor y reverençia de Nuestro Salvador Ihesu Christo con sus doçe apóstoles”, debiendo dichos pobres comer públicamente las raciones -pan, vino y carne- dentro del templo, donde les eran repartidas. LOP OTÍN, M. J., El cabildo catedralicio de Toledo en el siglo XV, p. 365. 
en el chantre la generosa iniciativa de este evangélico convite, claro acto en todo caso de publicitación de la caridad eclesiástica, narrado piadosamente en los siguientes términos:

...En todas las fiestas de nuestro Señor e de nuestra Señora la Vyrgen María, e de todos los apóstoles e de San Juan tenía por combydados a comer treze [pobres] más menesterosos que se fallavan en la çibdad, e el modo del combyte hera este. Que segund el tiempo de carne o pescado se buscava e compraba lo mejor que se podía aver, e poníanles su aparador de plata adornado como si los prinçipales de la çibdad e más ricos ovieran allí de comer...con jarros e fuentes de plata. El maestresala deste serviçio era el santo chantre, çenydo un paño de lienço muy deçentemente, e asy suçedía la comida de los combydados comiendo cada uno en su plato de plata, e ninguno podía poner ni quitar salvo el maestresala al qual servían los de su casa fasta dar e tomar los platos e escudillas en sus manos. E acabada la comyda e dicha la bendyçión, e aliadas las mesas quedaban escusentados los combydados, e salían fuera algunos de los familiares e quedavan con él dos o tres solamente. E luego traían un baçín de metal muy lympio con agua cozida con buenas yerbas de buenos olores e descalçávanse todos sus pies, e el mismo combydante se syntaba de rodyllas delante de cada uno e lavá[bales] los pies con muchas lágrymas e se los alimpiaba con el lienço que tenía çeñido con mucha umyldad, e daba a cada uno un par de çapatos nuevos que se calçasen e un real de plata en dynero para su nesçesydad, e así se yvan e despedían estos combydados dándole graçias al señor e bendiziéndolo muy devotamente ${ }^{146}$.

A esta singular y generosa ceremonia se añadían las limosnas que, según su biógrafo, entregaba cuando se predicaba en Cuenca la redención de los cautivos ${ }^{147}$, invitando también a comer a los predicadores, y asimismo al parecer enviaba cada año varios paños de lana y lienzos a los hospitales de San Lázaro de su tierra de Astorga, para vestir pobres ${ }^{148}$.

En definitiva, la generosidad del chantre hacia los sectores más desfavorecidos de la sociedad parece ser un hecho sobradamente constatado, si bien es cierto que todo este despliegue de limosnas y donativos únicamente podía ser llevado a cabo por alguien con una elevada posición social y económica como la que él tenía, contribuyendo así a consolidar y publicitar su estatus de privilegio en la sociedad conquense

146 ACC, Obras Pías, leg. 315, exp. 3.

147 La predicación para la redención de los cautivos tenía un carácter itinerante por diferentes ciudades, y en Cuenca se realizaba periódicamente en la catedral y en otras partes de la ciudad. Además había en Cuenca dos monasterios de órdenes de redención de cautivos, el de Santa María de la Merced, ya desde el siglo XIII, y el de la Trinidad, desde fines de la centuria siguiente. Véase al respecto mi mencionado libro, Iglesia, sociedad y poder en Castilla..., pp. 279-281, y 285. Sobre la orden de los mercedarios y su papel en la redención de los cautivos hay que destacar el amplio estudio de MILLÁN RUBIO, J., La Orden de Nuestra Señora de La Merced (1301-1400), Roma, 1992.

148 ACC, Obras Pías, leg. 315, exp. 3. En esta época el hospital de San Lázaro de Astoga llegó a adquirir un destacado relieve como centro asistencial hacia pobres y peregrinos. Véase al respecto el trabajo de QUINTANA PRIETO, A., "El hospital de San Lázaro de Astorga", Compostellanum, 35 (1990), pp. 411458, y 39 (1994), pp. 391-459. El apoyo económico por parte del clero fue fundamental para la dotación y mantenimiento de algunos de los numerosos hospitales que había en la ciudad y diócesis de Astorga. Vid. CAVERO DOMÍNGUEZ, G., "Fundaciones hospitalarias del clero secular en la diócesis de Astorga (siglos XII-XV)", en El Camino de Santiago, la hospitalidad monástica y las peregrinaciones, Valladolid, 1992, pp. 135-148. 
del momento, en una época en que la limosna y ayuda a los pobres se concebían ante todo como una forma de ejercicio de la caridad cristiana, pero sin que existiesen todavía proyectos bien definidos y eficaces para intentar erradicar o al menos mejorar sustancialmente un problema estructural de la sociedad como era el de la pobreza.

Más difícil, sin embargo, resulta establecer, ante la falta de datos documentales fehacientes que lo corroboren, el grado de credibilidad que puede otorgarse a otra faceta de la religiosidad del chantre destacada también por su primer biógrafo, como fue la realización de romerías y peregrinaciones. Sea como fuere, y sobre una posible realidad de fondo ${ }^{149}$, en primer lugar se señala que estando estudiando en Bolonia acudió a visitar los santuarios sagrados de Roma. También nos dice que, cuando contaba con sesenta y seis años de edad, peregrinó a Santiago de Compostela, "a pie syn bestias con dos o tres cryados clérygos", ganando el jubileo que había aquel año ${ }^{150}$; luego volvió por Asturias, visitando las reliquias de la cámara santa de Oviedo, continuando su camino por Zamora, Salamanca y el santuario de la Peña de Francia, hasta llegar a Guadalupe, desde donde regresó a Cuenca pasando por Toledo ${ }^{151}$. El anónimo biógrafo llega a decirnos que "yo tuve en mis manos muchas veçes aquel bordón e el sombrero con las conchas de la romería que oy permanesçen". Finalmente, se destaca también que el chantre, durante sus largos años de estancia en Cuenca, acostumbraba realizar los sábados -día especialmente dedicado a la Virgen ya en esta época-, poco después del alba, un recorrido por la ciudad para visitar algunas iglesias, hospitales, ermitas y monasterios, comenzando por San Pedro, en la parte alta de la ciudad, continuando luego hacia la parte baja hasta llegar, ya extramuros, a la pequeña ermita de Santa María de la Puente ${ }^{152}$-donde él mismo o uno de sus capellanes decían misa-, el

149 Durante el siglo XV, y también posteriormente, son habituales en la documentación capitular de las catedrales castellanas las noticias sobre concesión de licencias de ausencia a los canónigos para poder acudir en peregrinación a lugares sagrados, generalmente a Santiago y Guadalupe, sobre todo en años jubilares. Sin embargo no he podido encontrar en las Actas capitulares conquenses ninguna noticia sobre una supuesta concesión de dicha licencia al chantre Nuño Álvarez.

${ }^{150}$ Atendiendo a los datos que proporciona el biógrafo, esta peregrinación debería haberse realizado hacia 1466, pero sabemos que este no fue año jubilar. Sí que lo fueron otros años como 1456, 1457 o 1462 , por lo que, en el supuesto de haber realizado Nuño Álvarez dicha peregrinación en año jubilar, tuvo que haber sido uno de estos últimos años. Vid. LÓPEZ FERREIRO, A., Historia de la santa iglesia de Santiago de Compostela, Santiago, 1904, vol. VII, pp. 209 y 403.

151 La noticia de la peregrinación a pie por parte del chantre a varios lugares sagrados del reino de Castilla también es recogida por SILVESTRE DE VELASCO Y HERRERA, S., Compendio de la nobilíssima fundación... y vidas y gloriosas muertes de Sr. San Pedro de Arbues y venerable Nuño Álvarez Ossorio..., pp. 192-194. Por el testamento de Nuño Álvarez sabemos que éste conocía al prior general de San Bartolomé de Lupiana y a algún fraile de la orden de San Jerónimo, y al parecer mantenía también ciertos contactos con gentes de Santiago de Compostela, lo que en cierto modo podría avalar indirectamente su posible peregrinación años atrás a varios santuarios castellanos. ACC, Obras Pías, leg. 315, exp. 2/1.

${ }^{152}$ La devoción hacia esta pequeña ermita, vinculada al convento de los Antoneros, está bien documentada ya desde el siglo XV. Así, por ejemplo, en el testamento de doña Teresa de Luna, tía del condestable don Álvaro de Luna, otorgado el 10 de noviembre de 1430, se deja una pequeña manda de cincuenta maravedís "para la obra de Santa María de la Puente de la dicha çibdad de Cuenca". ACC, caj. 8, leg. $32, \mathrm{n}^{\circ} 652$. Asimismo también hay constancia documental de que las misas y ofrendas devocionales en esta ermita solían realizarse los sábados, lo que vendría a corroborar en cierto modo los datos que nos ofrece el anónimo biógrafo del chantre. Por ejemplo, algunos años después de la muerte de este último, el 14 de noviembre de 1502, el regidor conquense Fernando de Beteta estableció en su testamento que se dijese perpetuamente cada sábado en la ermita de Nuestra Señora de la Puente una misa rezada y una salve cantada por su alma. Archivo Municipal 
hospital de San Lázaro y el monasterio de la Trinidad, para finalizar visitando la iglesia del hospital de Santiago y el monasterio benedictino de Santa María de la Contemplación que él mismo había fundado, subiendo luego a la misa en la catedral ${ }^{153}$.

Un aspecto particularmente relevante que hay que destacar en la figura del chantre Nuño Álvarez es su labor de mecenazgo hacia determinadas órdenes religiosas, y más concretamente hacia los benedictinos en su rama femenina, lo cual debe situarse en el contexto de la reforma de las órdenes religiosas en Castilla durante el siglo XV. El monasterio que, a mediados de siglo, fundó Nuño Álvarez fue el de Santa María de la Contemplación, de monjas benedictinas, tratándose del primer centro monástico femenino que se estableció dentro de la propia ciudad de Cuenca, concretamente junto a la parroquia de San Salvador, donde todavía persiste en la actualidad. En el momento de su fundación las órdenes religiosas que contaban con una mayor presencia en el conjunto del obispado conquense eran los franciscanos y dominicos, seguidos por mercedarios y trinitarios, mientras que los benedictinos apenas estaban presentes ${ }^{154}$.

Según Trifón Muñoz y Soliva, antiguo cronista local conquense cuyos testimonios son poco fiables, este monasterio de monjas benedictinas había sido con anterioridad una casa de beaterio ${ }^{155}$, pero lo cierto es que nada puede asegurarse al respecto. Al frente de la comunidad se encontraba una priora, cargo que en 1451 ostentaba la dueña María González, la cual probablemente fue la primera en ejercerlo ${ }^{156}$.

El proceso inicial de dotación de la nueva comunidad monástica corrió fundamentalmente a cargo de su fundador. Así, el 19 de agosto de 1451 nos encontramos con un documento mediante el cual el entonces obispo de Cuenca, Fray Lope de Barrientos, dio comisión a su provisor para anejar dos prestameras de las parroquias de Fuentes y Chillarón (de Pareja) al recién fundado monasterio de benedictinas de Cuenca, prestameras que pertenecían al chantre Nuño Álvarez y con las que éste

de Cuenca, leg. 1262, exp. 9, nota 6. Y el 4 de enero de 1527 el canónigo Pedro del Pozo pidió al cabildo catedralicio que "porque tenía devoçión e prometido de dezir todos los sábados misa en Nuestra Señora de la Puente, que le mandasen dar liçençia para ello e que aquellos días no le hiziesen falta en la iglesia". ACC, Actas Capitulares de 1527, f. 15v.

153 ACC, Obras Pías, leg. 315, exp. 3.

${ }^{154}$ Sobre la implantación de las diferentes órdenes religiosas en el obispado de Cuenca puede verse mi citado trabajo Iglesia, sociedad y poder en Castilla ..., pp. 279-316. Respecto a los monasterios franciscanos, en particular, véase mi artículo "Monasterios franciscanos en la diócesis de Cuenca durante la Edad Media", Archivo Ibero-Americano, 230 (1998), pp. 311-336.

${ }^{155}$ MUÑOZ Y SOLIVA, T., Noticias de todos los ilustrísimos señores obispos que han regido la diócesis de Cuenca, Cuenca, 1860, p. 141. Sí que se conservan sin embargo otros datos perfectamente documentados, de época posterior, relativos a la presencia de beatas en la ciudad de Cuenca. Así, por ejemplo, el 26 de febrero de 1496 el cabildo catedralicio otorgó poder a Juan de Iranzo, canónigo, "para que fable con el señor provisor e pida liçençia para que se faga una casa junto con la eglesia, en el anden junto con la de Sant Iohan, junto con el escritorio que tiene Juan de Cuellar, para que se faga una casa para que esté emparedada María la beata". ACC, Actas Capitulares de 1496, f. 49v. Algunos años más tarde, el 10 de enero de 1504, el cabildo acordaría "que la casa que está en el andén de la dicha yglesia, que se fizo para la enparedada que agora fallesçió, que sea para la beata o beatas e que non se convierta en otros usos". ACC, Actas Capitulares de 1504, f. 77v; y el día 19 del mismo mes el cabildo estableció "que deven de entrar en la dicha casa para enparedarse en ella y faser su vida allí para servir a mi señor Juana la beata e la fija de Pedro buonero, la beata”. Ibídem, f. 80r.

156 AHPC, Hacienda, 141, Clero/Benitas nº 4, exp. 6 (olim Desamortización, leg. 511). 
deseaba establecer sendas capellanías en el monasterio ${ }^{157}$. Poco después, en virtud de dicha comisión, el provisor Sancho Ruiz, arcipreste de Olmedo, "anexó las dichas dos prestameras al monesterio de señora Santa Marya de la Contenplaçión, para dos capellanías perpetuas que se canten en el dicho monesterio". Estas dos capellanías se habrían de celebrar por el alma del fundador ${ }^{158}$.

Si damos por ciertos los datos que se recogen en la primera biografía escrita sobre el chantre, parece ser que en ocasiones el propio Nuño Álvarez incluso se encargó de presentar a algunas novicias para su ingreso en la comunidad, instruyéndolas personalmente en la doctrina cristiana, y entregando frecuentes limosnas a favor del monasterio ${ }^{159}$. Por otro lado, según se recoge en su testamento, el chantre estableció que en el monasterio por él fundado se cantasen por su alma un anual y un treintenario, encargándose un capellán de decir las misas correspondientes, y quedando las monjas obligadas a ayunar por su alma durante los treinta días que durase el treintenario. Además, en el testamento también donó al monasterio un misal nuevo para servicio del altar de la iglesia, así como varias ollas y cántaros ${ }^{160}$. Según el biógrafo del chantre, cuando ocurrió su fallecimiento al frente de la comunidad se encontraba la priora María de Almendros ${ }^{161}$, sobre lo cual únicamente podemos asegurar que dicha priora ocupaba el cargo bastantes años más tarde, concretamente en $1507^{162}$.

Pero el chantre Nuño Álvarez no fue el único benefactor de esta comunidad de religiosas, aunque sí el principal. Por ejemplo, el 27 de abril de 1451 Rodrigo de Cañizares, vecino de Cuenca y miembro de una importante familia de la oligarquía urbana, donó al monasterio a perpetuidad, actuando como testigo el propio chantre, una viña situada en el pago detrás de la Fuent Santa, a cambio de que anualmente se dijera un oficio el martes de Pascua de Resurrección y al día siguiente una misa de Requiem cantada por las almas de sus padres y difuntos y por la suya propia cuando muriese ${ }^{163}$. Sin duda, esta donación debe situarse también dentro del proceso inicial de dotación de la nueva comunidad monástica recién fundada, siendo probable, asimismo, que la priora María González y las primeras monjas aportaran algunos bienes al ingresar en el monasterio ${ }^{164}$.

157 AHPC, Hacienda, 141, Clero/Benitas nº 4, exp. 7 (olim Desamortización, leg. 511).

158 El 18 de diciembre de 1451 Pascual de Torralba, criado del canónigo conquense Alfonso García de San Felices, como procurador de María González, priora del monasterio, tomaría posesión de la ración prestamera en la parroquia de Chillarón a la que el chantre había renunciado. AHPC, Hacienda, 141, Clero/Benitas nº 4, exp. 6 (olim Desamortización, leg. 511).

159 ACC, Obras Pías, leg. 315, exp. 3.

160 ACC, Obras Pías, leg. 315, exp. 2/1.

161 ACC, Obras Pías, leg. 315, exp. 3.

162 AHPC, Hacienda, 138, exp. 4 (olim Desamortización, leg. 136). Se trata de una carta de censo en la que aparece la "noble señora" doña María de Almendros, priora del monasterio de Santa María de la Contemplación de Cuenca.

163 AHPC, Hacienda, 138, exp. 2 (olim Desamortización, leg. 136).

164 Se conserva entre la documentación perteneciente al monasterio una carta de donación fechada en Cuenca el 19 de abril de 1444 a través de la cual una tal doña Estefanía, viuda de Juan Martínez de Cuenca y vecina deVillar de Olalla, hace entrega de una viña en término de Albaladejo a María González de las Muelas, vecina de Cuenca perteneciente a un destacado linaje de la oligarquía urbana, y no cabe menos que sospechar que, aunque no se alude a dicha María González como priora del monasterio, quizá se trate del mismo personaje que pocos años después figura en la documentación ocupando dicho cargo, en cuyo caso la 
Asimismo, ciertos eclesiásticos muy próximos al chantre también se preocuparon por favorecer al monasterio. Tal sería el caso del canónigo conquense Diego de Valera, a quien el chantre en su testamento concedería el privilegio de poder enterrarse en su capilla de San Miguel "por grande amor e afectión que con él tenya", actuando asimismo como testamentario. Dicho Diego de Valera, el 29 de abril de 1470, compró a Pedro Fernández de la Vieja, hijo de un escribano público del mismo nombre, sus derechos sobre un censo perpetuo de 400 maravedís anuales situado sobre unas casas en la Correría de Cuenca, una de las calles principales de la ciudad, a cambio del pago de 8000 maravedís; con posterioridad, en algún momento indeterminado, pero seguramente en vida de Diego de Valera o por disposición testamentaria de éste, dicho censo terminaría cediéndose a las monjas de Santa María de la Contemplación, que un siglo más tarde todavía lo percibían ${ }^{165}$.

Posteriormente el monasterio seguiría recibiendo otras donaciones diversas por parte de eclesiásticos o vecinos de Cuenca y sus aldeas, siempre a cambio de la celebración de misas y aniversarios. De este modo se formaría un pequeño patrimonio constituido por casas, heredades y viñas sobre todo en Cuenca y sus alrededores próximos -por ejemplo, en el término de Albaladejo-, que se explotaba mediante su entrega a censo y que era administrado por un mayordomo, cargo que generalmente recaía en un laico ${ }^{166}$.

Finalmente hay que señalar que, junto a esta importante fundación monástica, la historiografía local conquense también ha atribuido tradicionalmente al chantre el haber ayudado a la reedificación de la ermita de San Cristóbal, situada en el cerro que estaba por encima del castillo ${ }^{167}$, y a la construcción de un puente sobre el río Júcar, que sería conocido como puente del chantre, situado a unas pocas leguas de la ciudad $^{168}$.

mencionada viña es posible que formara parte de los bienes que pasaron a propiedad del monasterio tras su ingreso en la comunidad. AHPC, Hacienda, 138 (olim Desamortización, leg. 136).

165 AHPC, Hacienda, 138, Clero/Benitas nº 1, exp. 1 (olim Desamortización, leg. 136).

166 Alguna documentación sobre los censos del monasterio a fines de la Edad Media y sobre todo durante la Edad Moderna puede verse en: AHPC, Hacienda, 138 (olim Desamortización, leg. 136).

${ }^{167}$ Esta ermita existía al menos desde 1430, pues en el ya citado testamento de doña Teresa de Luna, otorgado el 10 de noviembre de dicho año, se deja a su favor una pequeña manda de cinco maravedís. ACC, caj. 8 , leg. 32, $\mathrm{n}^{\mathrm{o}} 652$. El biógrafo conquense del chantre, muy piadosamente, nos dice de éste que, en el mismo año en que falleció, siendo por tanto de muy avanzada edad, "le ví yo por mis ojos que con sus propias manos e otros canónigos de aquella yglesia traían piedras para rehedifycar la hermita del señor San Cristóval, que es en el çerro alto ençima de la fortaleça de la çibdad, donde muchos dyas subyan él e otros señores de aquella yglesia con devoçión para reparar aquella hermita con sus limosnas, dando él la yndustria dello...”. ACC, Obras Pías, leg. 315, exp. 3. Este fragmento de la biografía, muy en la línea de los textos hagiográficos, constituye un claro ejemplo de exaltación del esfuerzo y trabajo manual como una de las virtudes del chantre, a pesar de la avanzada edad de este último, motivo por el cual no cabe sino poner muy en duda la plena veracidad de estas afirmaciones

168 TRENCHS ODENA, J., "La cultura jurídico-piadosa...”, p. 36; ACC, Obras Pías, leg. 315, exp. 3. Es interesante que el paraje natural junto a dicho puente en la ribera del Júcar se denomine actualmente como "el chantre". 


\section{EL TESTAMENTO Y LA MUERTE DEL CHANTRE}

El testamento del chantre Nuño Álvarez de Fuente Encalada fue otorgado en Cuenca el 7 de agosto de 1476, pocos días antes de su muerte, ante el notario público Miguel Sánchez Zomeño, incorporándose algunas pequeñas adiciones a su contenido los días 9 y 10 del mismo mes ${ }^{169}$. En el momento de su redacción el chantre se encontraba bastante enfermo, "doliente en una cama", y de hecho en el testamento aparece una manda de un cahíz de trigo a favor de cierto "liçençiado físico" que "ha tenido cargo de mi casa", dato este último que denota la cualificación profesional del médico que le atendía ${ }^{170}$, a la vez que como testigos figuran, entre otros, el mencionado físico y el maestre Martín, cirujano ${ }^{171}$. Los testigos presentes a su otorgamiento el 7 de agosto fueron concretamente el canónigo Pedro de Párraga; el racionero Francisco Martínez de Baeza; fray Guillén, guardián del monasterio de San Francisco de Cuenca ${ }^{172}$, y fray Pedro de Peñalver, fraile del mismo monasterio; el licenciado físico; Juan Sánchez Cachero y Diego de Aranda, vecinos de Cuenca, y Juan de Ocaña, todos ellos criados del chantre; y el notario apostólico Miguel Sánchez Zomeño.

Formalmente y en su contenido, el testamento presenta similitudes con los de otros clérigos pertenecientes a la alta jerarquía eclesiástica durante esta época, como por ejemplo los de algunos miembros del cabildo catedralicio toledano ${ }^{173}$. La preocupación del chantre por el momento la muerte, por los pecados cometidos, y muy en

169 ACC, Obras Pías, leg. 315, exp. 2/1. Algunos fragmentos del testamento, fundamentalmente los referentes a la capilla de san Miguel, fueron publicados por PALOMO FERNÁNDEZ, G., La catedral de Cuenca..., vol. II, pp. 478-480.

170 En este período final de la Edad Media, los físicos que ejercían la medicina en Cuenca contaban a menudo con una formación académica relativamente sólida, exhibiendo titulaciones de licenciado y doctor, aunque también hubo médicos menos cualificados. En Cuenca, al igual que en otras ciudades, los judíos ocuparon un lugar destacado en la práctica médica, que en el siglo XV fue ejercida, junto a algunos cristianos, por personajes como Simuel Abenxuxén o Rabí Harón, judíos optenses. El primero de ellos, "don Simuel", como era conocido en Cuenca, ejerció su oficio durante no menos de cuarenta años, en la segunda mitad de siglo, y su prestigio local explica que a veces lo encontremos al servicio de personajes acomodados, como por ejemplo el canónigo Fernán Yáñez de Escalona, que en su testamento de 1462 no olvidó mencionar la necesidad de pagar a "don Simuel” por los servicios prestados. SÁNCHEZ BENITO, J. M., El espacio urbano de Cuenca en el siglo XV, pp. 108-111.

171 Dicho cirujano aparece como testigo en la adición al testamento del 9 de agosto. Sin duda se trata de Martín García de Cañete, cirujano del concejo conquense durante estos años. Los cirujanos eran especialmente requeridos cuando había que curar heridas o úlceras. Frecuentemente se les conocía con el título de maestre, y tenían cierto reconocimiento social. SÁNCHEZ BENITO, J. M., op. cit., p. 110.

${ }^{172}$ Es fray Guillén Gutiérrez, el mismo que dos años más tarde, en octubre de 1478, tomó juramento ante la puerta del Postigo a Fernando el Católico, cuando éste se disponía a entrar en la ciudad en la visita que hizo aquel año. SÁNCHEZ BENITO, J. M., op. cit., p. 129.

173 Formalmente estos testamentos siempre presentan un preámbulo introductorio con consideraciones diversas acerca de la muerte, una profesión de fe en los dogmas católicos y la encomendación a Dios del alma del difunto. Siguen luego las disposiciones sobre el modo y lugar de enterramiento, las mandas piadosas de mayor o menor cuantía a favor de todo tipo instituciones religiosas, seculares y regulares, los encargos de misas y aniversarios y, frecuentemente, la institución de alguna capellanía, tras lo cual se establecen las mandas de dinero y bienes a favor de parientes y familiares y se designa al heredero o herederos universales del resto de bienes, para terminar con el nombramiento de albaceas y testamentarios y otras disposisiones finales. Algunos de estos testamentos pertenecientres a miembros del cabildo catedralicio toledano aparecen recogidos en el trabajo de LOP OTÍN, M. J., El cabildo catedralicio de Toledo..., pp. 505-507, 512-516. 
particular por la posibilidad de que su alma fuese al purgatorio quedan bien patentes en el preámbulo introductorio:

...Manyfiesta cosa es segund dise santo Augostyni la muerte ser muy çierta a la hora della, e el logar y el modo e estado della seer a todos muy ynçiertos, e muchas veses acaesçen las muertes ser súbitas e otras vezes venyr grand fiebre e frenesçia e otras pasiones e dolores a la natura humana, por las [qua]les las personas están atormentadas e los sentydos están ocu[lta]dos e agravyados por causa de las pasiones e dolores de la muerte, e el entendimyento está turbado...e por tanto toda persona discreta debe faser su testamento en tiempo de la prosperidad e sanydad asy del ányma commo de la persona e del entendimyento e de los sentydos...E por ende yo Nuño Álvares de Fuente Encalada, chantre de la yglesia de Cuenca, aunque yndigno, de lybre en tiempo de la sanydad e prosperydad de my persona e del entendimyento e sentydos, quales me los quiso nuestro señor Dios dar, de faser my testamento...e la postrimera voluntad e disposiçión de los clérigos...ha de ser por vya de legados o mandas, desencargando sus conçiençias e satisfasiendo de las cosas de que han tenydo e tienen cargo, e mandando faser por sus ánymas algunos sufragios para redem[ir] las penas del purgatorio, porque nuestro señor Dios quyera a[ver miseri]cordia de las ánymas dellos e las quiera perdonar...e por aver expendidos los tiempos e hedades de la adolesçençia e jouventud e veges en vanydades e locuras e pompas del mundo, dándose a viçios e pecados e quitándose de las virtudes e del servyçio de nuestro señor Dios, e nemyne acusando estas cosas sobredichas sean dichas por my, en el qual fueron e son muchos más viçios e pecados e fablas e defectos que yo podría desyr e pensar, de los quales me acuso manyfiestamente e me arrepyento e digo my culpa averlos fecho, e demandando a my señor Ihesu Christo perdón, que le plega de aver mysericordia con my ányma, pues él la crió e redimyó por la su santysima pasión, la quiera levar a la su santa gloria...

En esta época ya estaba consolidada la idea de la existencia de un juicio particular inmediatamente después de la muerte, a raíz del cual el difunto recibía su veredicto, tras el que el alma accedía directamente al cielo, era condenada a los tormentos eternos del infierno o presumiblemente, según una creencia cada vez más extendida, era confinada en el purgatorio por un tiempo indefinido, durante el cual purgaría el castigo correspondiente por sus pecados hasta reunir los requisitos que le permitiesen entrar en el cielo. También se creía que, aunque en vida el difunto podía haber obtenido el perdón de su culpa mediante el sacramento de la confesión -tan frecuentemente practicada por el chantre, según sus biógrafos-, tras la muerte era muy posible que su alma tuviese que permanecer un determinado tiempo en el purgatorio con el fin de cumplir la parte correspondiente de la pena que, a juicio divino, quedase pendiente.

Aunque contando con algunos precedentes, por ejemplo en el pensamiento teológico de San Agustín o el papa Gregorio Magno, la doctrina del purgatorio había comenzado a definirse de una forma mucho más clara a partir de la segunda mitad del siglo XII. El tiempo de estancia en este lugar del más allá intermedio entre el cielo y el infierno dependía de tres factores. Ante todo debía ser proporcional a la cantidad de pecados cometidos por el difunto, en concreto aquellos pecados con los que cargaba en el momento de su muerte (los pecados llamados a partir de entonces "veniales", es decir, redimibles, pues los "mortales" eran irredimibles y por tanto no eximían del infierno). En segundo lugar, el tiempo dependía también de los sufragios (misas, ple- 
garias, limosnas, etc.) realizados por los vivos para abreviar el período de purgatorio de determinadas ánimas. Finalmente, la Iglesia podía obtener la remisión integral o parcial del tiempo que restaba por pasar en el purgatorio a determinados difuntos, normalmente previo pago en dinero de cierta cantidad: son las indulgencias, de cuyo comercio creciente se benefició la Iglesia a partir del siglo XIII. El purgatorio, finalmente, tenía como característica su orientación en una única dirección: no podía salirse del mismo más que para ir al paraíso, de manera que, una vez en él, nadie podía "retroceder" al infierno. Así, el purgatorio contribuyó a aumentar el poder de la Iglesia sobre los muertos, extendiendo así su potestad de jurisdicción al más allá del purgatorio, gracias a la gestión de los sufragios y de las indulgencias, que dependían de la propia Iglesia ${ }^{174}$.

En este sentido hay que recordar que, por ejemplo, el 31 de mayo de 1436 el obispo Álvaro de Isorna había solicitado al concilio de Basilea el otorgamiento de determinadas indulgencias a favor de la iglesia conquense ${ }^{175}$, siéndole finalmente concedidos, el 15 de junio, siete años y siete cuarentenas de perdón para las fiestas de la Natividad y Asunción de la Virgen ${ }^{176}$. Tan solo tres años más tarde, en el concilio de Florencia de 1439, la doctrina de la Iglesia sobre el purgatorio sería declarada como dogma ${ }^{177}$, siendo posible que por esas fechas Nuño Alvarez, finalizados ya sus estudios en Bolonia, todavía se encontrase en tierras italianas, preparando su regreso a Castilla.

Dentro de este marco ideológico y espiritual el chantre Nuño Álvarez, además de acumular méritos en vida con sus oraciones y el amplio despliegue de obras de caridad y mecenazgo religioso que llevó a cabo, también estaba plenamente convencido de que, tras su muerte, los sufragios, misas y oraciones de los vivos para que su alma saliese lo antes posible del purgatorio y alcanzase la salvación eterna eran algo absolutamente necesario.

Tras el mencionado preámbulo introductorio y la encomendación de su alma a Dios, manda ser enterrado ante el altar de Santa María de su capilla de San Miguel en la catedral, sin "cama alguna ni otra pompa salvo que me pongan en un atahúd en tierra e con el dicho atahúd e hornamentos saçerdotaes e mysa me entierren". Encarga a continuación que, mientras duren los oficios y misas por su alma, permanezcan encendidos trece cirios en honor de Cristo y los apóstoles, y que también se enciendan doce cirios en otros altares y tres antorchas "a honor e reverençia de la santa Trenydad". Los oficios y misas cantadas tendrían lugar en la catedral, y en su celebración, además del cabildo catedralicio con oficios y misa de Santa María, también debían participar los clérigos parroquiales de Cuenca con oficios y misa de la Trinidad, los frailes de San Francisco con una misa de la Natividad, los frailes de La Merced con

174 LE GOFF, J., "Más allá”, en LE GOFF, J., y SCHMITT, J.-C. (eds.), Diccionario razonado del Occidente medieval, Madrid, 2003, pp. 504-505. Véase un análisis mucho más amplio sobre el tema en el ya clásico trabajo de LE GOFF, J., El nacimiento del purgatorio, Madrid, 1985.

175 HALler, J. (ed.), Concilium Basiliense...Band IV: Protokolle des Concils von 1436, p. 156.

176 Ibídem, pp. 178-179.

177 Vid. PETIT, L., De purgatorio disputationes in concilio Florentino habitae, Roma, 1969. 
una misa del Espíritu Santo, los capellanes de la catedral con una misa de San Migue $^{178}$ y los canónigos extravagantes con una misa de Réquiem ${ }^{179}$.

A continuación establece que las monjas del monasterio de Santa María de la Contemplación celebren por su alma un anual con pan, vino y cera, según la costumbre de la época, para lo cual les deja cuatro cahíces de trigo y mil maravedís, además de otros tres mil maravedís para que las monjas paguen a un capellán "que sea buen clérigo e de buena vida e fama" que se encargue de decir una misa cantada cada día del anual. Asimismo manda también a las monjas que digan por su alma un treintanario, haciendo cantar cada día del mismo, durante treinta días, otra misa además de la del anual; de las misas del treintanario establece que se encargue Alfonso Sánchez de Huete, su confesor y capellán, pagándole por ello mil maravedís y dos cahíces de trigo. El chantre ruega que ambos capellanes, el del anual y el del treintanario, se confiesen cada día antes de decir las misas, y también pide a las monjas que ayunen por su alma mientras dure el treintanario, y que finalizado el mismo hagan cantar al capellán otras tres misas de la Trinidad, de forma que en total sean treinta y tres misas seguidas, lo que pone en evidencia la importancia que en la época se otorgaba al simbolismo numérico en su proyección religiosa. En el testamento se explicita que las misas del anual y del treintanario son "porque más ayna mi ányma salga del purgatorio, si a nuestro Señor Dios ploguiere de la levar del", contribuyendo a ello también el ayuno de las monjas y los cinco maravedís diarios que el capellán del treintanario debía entregar a los pobres como limosna.

También manda que un capellán "de buena vida" diga otro anual por su alma en su capilla de San Miguel, con una misa cantada diaria, pagándole por este trabajo tres mil maravedís. Deja asimismo al cabildo catedralicio mil maravedís para que hagan oficios y rueguen a Dios por su alma, dándose por satisfechos de las pitanzas y horas mal ganadas por él y de cualquier dinero que les debiese. En el testamento también se ratifican la donación al cabildo de su librería particular y el encargo y dotación de la celebración de cinco memorias y aniversarios perpetuos, según se había establecido años atrás. Sobre todo ello, así como sobre algunos nuevos libros que en el testamento fueron objeto de donaciones diversas, ya se ha hablado en páginas anteriores.

Nuño Álvarez también dejó en su testamento unas casas nuevas que tenía en el barrio de San Pedro, la mitad de cuyas rentas sería para la maitinada continua y para que los canónigos extravagantes celebrasen en su capilla de San Miguel dos memorias anuales por su alma, una el segundo día del Adviento y la otra el primer día de Cuaresma, especificándose que "porque muchos canónigos extravagantes e capellanes e otros benefiçiados procuran de venyr en cobdiçia desornada en los dichos días que se fisieren las dichas dos memorias, más por ganar los dyneros que por rogar a Dios por my ányma... por ende mando e hordeno que non pueda alguno ganar nin aver parte en los dichos dyneros de las dichas memorias salvo los benefiçiados e

${ }^{178}$ El colectivo de capellanes de la catedral de Cuenca se agrupaba, al menos desde mediados del siglo XIV, en el llamado cabildo de San Ildefonso y Corpore Christi. Algunos de estos capellanes eran criados o familiares de los canónigos y dignidades del cabildo catedralicio.

179 Los llamados canónigos extravagantes participaban en el culto catedralicio y en el rezo de las horas a cambio de una pequeña remuneración económica, engrandeciendo así las ceremonias de la catedral dadas las frecuentes ausencias de los canónigos titulares, pero no tenían voz ni voto en las reuniones capitulares, y en nada se pueden asimilar al cabildo de canónigos. 
capellanes e canónigos extravagantes que por un mes antes, ynterpolado o continuo, vinieren a maytines, convyene a saber que desde Sant Iohan fasta el Aviento venga a maytines un mes el que ovyere de ganar los dyneros que se repartieren a la memoria que se fisiere el segundo día del Aviento, e desde Navydad fasta primero día de quaresma vengan un mes a maytines el que ovyere de ganar los maytines e dineros que se repartyeren en la memoria que se fisiere el primero día de quaresma". De lo que rindiesen dichas casas, en todo caso cuatrocientos maravedís anuales serían para que el cabildo catedralicio celebrase, también en su capilla, otras dos memorias perpetuas por su alma cada año, una en San Miguel de mayo y otra en San Miguel de septiembre. Se especifica asimismo que, en caso de que su sobrino Luis de Fuente Encalada quisiera establecerse a vivir en Cuenca, pudiera hacerlo en dichas casas pagando de renta anual mil maravedís, que se destinarían a las memorias y maitinada susodichas.

Hay que destacar especialmente la particular devoción manifestada por el chantre hacia el arcángel San Miguel, protector de las almas de los fieles cristianos frente a las tentaciones del diablo, particularmente durante la gran batalla espiritual por la salvación que se libraba en el momento de la muerte. En este senido no es en absoluto casual la extraordinaria difusión que durante la baja Edad Media adquirió en toda la cristiandad el culto a este santo, que junto a San Lázaro se convirtió en uno de los intercesores más frecuentemente invocados para conseguir una buena muerte y la correspondiente salvación ${ }^{180}$. Algunos años antes de morir Nuño Álvarez había mandado construir a sus expensas una capilla privada en la catedral conquense, en concreto la actualmente desaparecida capilla de San Miguel. En efecto, el 13 de junio de 1464 el chantre recibió licencia del cabildo para edificar una capilla propia en la catedral, que quedaría bajo la advocación de San Miguel ${ }^{181}$. Para dotarla, el 30 de marzo de 1475 pidió al cabildo que se anexaran a esta capilla las rentas de una prestamera que tenía en la parroquia de San Esteban de Cuenca, para que se destinasen a la compra de aceite y ornamentos litúrgicos y para la propia fábrica de la capilla ${ }^{182}$, que tomaría posesión de dicha prestamera el 7 de octubre ${ }^{183}$, siendo confirmada la anexión por el papa Sixto IV el 6 de diciembre del mismo año ${ }^{184}$.

En el testamento del chantre la capilla donde desea ser enterrado se menciona como ya construida. Asimismo Nuño Ảlvarez dejó, como vínculo perpetuo patrimonial para el mantenimiento de dos capellanes que la sirviesen, las heredades que poseía en Belmontejo, Fuentes Claras y Mohorte, junto con tres pares de casas que tenía en Cuenca, en el barrio de Zapatería y en San Pedro ${ }^{185}$. Dichos capellanes, nombrados

180 VOVELLE, M., La mort et l'Occident de 1300 à nous jours, París, 1983, pp. 93 y ss.

181 PALOMO FERNÁNDEZ, G., La catedral de Cuenca en el contexto de las grandes canterías catedralicias castellanas en la baja Edad Media, Cuenca, 2002, vol. II, p. 129.

182 PALOMO FERNÁNDEZ, G., La catedral de Cuenca ..., vol. II, p. 129.

183 Ibídem, vol. II, p. 129. La documentación referente a la cesión de la prestamera de San Esteban se encuentra en ACC, Obras Pías, leg. 314, exp. 1. Las rentas de esta prestamera estuvieron siempre vinculadas a la capilla de San Miguel que había fundado el chantre, hasta la desamortización eclesiástica del siglo XIX. ACC, Obras Pías, libro 89: "Libro de la prestamera de San Esteban aneja a la fábrica de la capilla de San Miguel" (años 1730-1842).

184 ACC, Obras Pías, leg. 315, exp. 10; Archivio Segreto Vaticano, Reg. Lat. 763, ff. 165r-166r.

185 En una relación de censos sobre propiedades urbanas que el cabildo catedralicio tenía en el año 1495 , estas casas en el barrio de San Pedro que había dejado el chantre Nuño Álvarez aparecen como entregadas a 
por el patrón de la capilla, debían decir una misa diaria de forma alterna, cada semana un capellán, además de celebrar los oficios religiosos correspondientes a algunas festividades especiales, como las de la Virgen y San Miguel, por quienes el chantre sentía una especial devoción.

Llama la atención la condición de no ser "públicos concubinarios" que el chantre exigió para los dos capellanes que habrían de servir en su capilla. En este sentido hay que recordar que la legislación prohibiendo que los clérigos de órdenes mayores vivan en concubinato es una constante en muchos concilios y sínodos bajomedievales hispánicos, siendo su reiteración una clara señal del frecuente incumplimiento del celibato eclesiástico, lo que también fue objeto de denuncia en varias reuniones de las Cortes castellanas, si bien entre los laicos cabe observar una cierta aceptación social de la barraganía clerical ${ }^{186}$. Lo cierto es que la legislación sinodal conquense también se ocupó reiteradamente del problema, de difícil resolución. Así, en las constituciones sinodales otorgadas por el obispo Juan Cabeza de Vaca en 1399 se señalaba la necesidad de imponer castigos a algunos clérigos y capellanes perpetuos del obispado que "queriendo más complaçer sus apetitos...dexan de servir a Dios en sus yglesias...segund que fallan sus plaseres y sus solazes carnales" ${ }^{187}$, prohibiéndose a los clérigos de órdenes mayores, incluidas las dignidades catedralicias, tener públicamente concubina, so pena de pérdida de sus beneficios, y estableciéndose también que los clérigos no beneficiados con concubinas no pudiesen obtener ninguna capellanía perpetua hasta transcurrido un año desde el abandono de su concubina ${ }^{188}$. Medidas similares contra el concubinato clerical, sobre todo cuando era "público", se reiteraron en los sínodos de Juan Cabeza de Vaca de $1402^{189}$ y $1404^{190}$, en los de

Fernando Pérez de Párraga, que pagaba a cambio una renta anual de 2000 maravedís. Cerca de estas casas se situaban otras que también había dejado al cabildo el deán Nicolás Martínez de la Campana, entregadas a censo al mismo personaje por 2100 maravedís anuales. AHPC, olim Desamortización, leg. 249. Véase al respecto mi trabajo "Propiedades censuales del cabildo catedralicio conquense a fines del siglo XV. Un documento para su estudio", Archivo Conquense, 1 (1998), p. 51. Respecto a las casas que tenía el chantre en el barrio de Zapatería, probablemente sean las mismas casas en dicho barrio que el 24 de junio de 1460 cedió Rodrigo, nieto de Fernando Manuel, a su primo Juan Sánchez de Montesinos, y que dicho Rodrigo había recibido por herencia de su abuelo, encontrándose esta cesión inmobiliaria entre los documentos pertenecientes a la capilla de San Miguel. ACC, Obras Pías, leg. 315, exp. 7.

${ }^{186}$ Sobre ello pueden verse, entre otros, los trabajos de ARRANZ GUZMÁN, A.: "Celibato eclesiástico, barraganas y contestación social en la Castilla bajomedieval", Espacio, Tiempo y Forma. Serie III. Historia Medieval, 21 (2008), pp. 13-39; y "Amores desordenados y otros pecadillos del clero", en CARRASCO MANCHADO, A. I, y RÁBADE OBRADÓ, M. P. (coords.), Pecar en la Edad Media, Madrid, 2008, pp. 227-262; así como el artículo de SÁNCHEZ HERRERO, J., "Amantes, barraganas, compañeras, concubinas clericales", Clio \& Crimen, 5 (2008), pp. 106-137.
${ }^{187}$ ACC, Libro de Estatutos, f. 37v.
${ }^{188}$ Ibídem, ff. 35v-36v.
${ }^{189}$ Ibídem, ff. 51r-52v.
${ }^{190}$ Ibídem, f. $57 \mathrm{v}$. 
Lope de Barrientos de $1446^{191}$ y $1457^{192}$, a los que asistió Nuño Álvarez, y en el de Alonso de Burgos de $1484^{193}$. Es por ello por lo que cabe pensar que el chantre sin duda conocía toda esta normativa sinodal sobre el concubinato clerical, y la realidad de un problema que también había sido objeto de duras condenas, un siglo atrás, por parte de Álvaro Pelayo en su De statu et planctu Ecclesiae, uno de los libros pertenecientes a la biblioteca del chantre.

Estableció también que de sus bienes se comprara una casa para dar a cambio de otra que estaba junto a su capilla, debiendo ser derribada una parte de esta última casa para que entre ella y la capilla quedase un tramo suficiente de calle libre, que tendría que enlosarse con buena piedra alrededor de la capilla para que en ésta no entrase agua y humedades. A su muerte debía quedar como patrón de la capilla su sobrino, Luis Álvarez de Fuente Encalada, y después el deán y cabildo catedralicio conquense. También podrían enterrarse en la capilla su criado Pedro de Sanabria con su mujer, a quienes el chantre cede tres mil maravedís, si bien dos días después, el 9 de agosto, el chantre amplió este derecho de enterramiento a todos sus criados, así como al canónigo conquense Diego de Valera "por grande amor e afectión que con él tenya e por muchos travajos que con él avía pasado en esta su dolençia". Años más tarde, en 1493, este último traspasó dicha sepultura a Gómez Ballo, arcediano de Cuenca, a quien corresponde el sepulcro situado hoy en el segundo tramo desde la entrada principal de la catedral, en la nave del lado norte ${ }^{194}$. Así, por tanto, vemos que la capellanía perpetua fundada por el chantre iba a ser inicialmente de patronato particular y familiar, siendo el patrono su sobrino, y únicamente tras la muerte de este último pasaría el cabildo catedralicio a ejercer la titularidad de dicho patronato ${ }^{195}$.

Sigue a continuación una amplia serie de mandas en dinero, cuyo montante global supera los 150.000 maravedís, a favor de casi una veintena de particulares, familiares

191 Synodicon Hispanum, vol. X, pp. 232-233, 293-294. Se establece, bajo penas económicas diversas, que "ninguno nin algunos de los clérigos e capellanes, así benefiçiados en la nuestra iglesia como en la çibdad e obispado, e los non benefiçiados, non sean osados de çelebrar misa en presençia de sus proprias concubinas". El carácter "público" de la concubina respecto a un clérigo venía dado también cuando vivía "en su casa o fuera della por ellos y en nombre dellos". En el mismo sínodo se recrimina y castiga con una multa a los beneficiados de la catedral que fuesen públicos concubinarios "por cada vegada que sus concubinas entraren en la iglesia, estando ellos en el coro diziendo el ofiçio, aunque non çelebren”. Ibídem, p. 295.

192 Ibídem, pp. 346-347.

193 Ibídem, p. 375. Un estudio y primera edición moderna de las actas del sínodo conquense de Alonso de Burgos de 1484 aparecen recogidos en mi trabajo "Fray Alonso de Burgos y el sínodo conquense de 1484", Hispania Sacra, 47 (1995), pp. 299-346.

194 PALOMO FERNÁNDEZ, G., La catedral de Cuenca..., vol. II, pp. 129-130, y 476. El biógrafo conquense del chantre nos dice que en la capilla de san Miguel también se enterró el canónigo Lorenzana, su confesor, fallecido unos años antes. ACC, Obras Pías, leg. 315, exp. 3. La capilla de san Miguel, que se encontraba al comienzo de la nave norte, desapareció con la demolición a principios del siglo XX de la antigua fachada de la catedral conquense, y apenas conocemos, por testimonios diversos, el aspecto que debía presentar a fines de la Edad Media, ya que en el siglo XVIII estuvo también sometida a un proceso de reconstrucción. Ibídem, p. 130. Algunos documentos referentes a la capilla aparecen recogidos en la mencionada obra, pp. 476-478.

195 A partir de mediados del siglo XVI, muerto ya Luis de Fuente Encalada y siendo el cabildo catedralicio patrono de la capilla, sendos puestos de capellán comenzarían a cubrirse por el sistema de oposición. La documentación sobre los opositores a la capellanía hasta el siglo XIX en: ACC, Obras Pías, leg. 315, exp. 1. 
y protegidos suyos ${ }^{196}$. Especialmente interesante es la manda de dos mil maravedís que el chantre dejó a favor del ya anciano canónigo Juan Carrillo, que en 1433 también había acudido, como capellán de Juan II y arcediano de Cuenca, al concilio de Basilea, donde sin duda tuvo que coincidir algún tiempo con Nuño Álvarez, siendo después durante décadas compañeros en el cabildo catedralicio conquense ${ }^{197}$. Además, el chantre también dejó mil maravedís a los frailes de San Francisco de Cuenca, y mandó "que los niños que están por criar que los crien a my costa, e que después que los den a quien mis testamentarios quisieren".

Finalmente, nombró como heredero universal del resto de sus cuantiosos bienes a su sobrino, Luis de Fuente Encalada, designando asimismo como sus testamentarios al prior de Belmonte y a Diego de Valera, canónigos, a su confesor y capellán Alfonso Sánchez de Huete, y a su propio sobrino.

Dos días más tarde, el 9 de agosto, Nuño Álvarez incorporó algunas nuevas cláusulas al testamento. Primeramente mandó que de sus bienes se pagasen mil maravedís a cierta persona de Santiago de Compostela, según había estipulado en su testamento el ya difunto Alfonso Estébanez, conocido del chantre, dado que dichos mil maravedís al parecer habían sido robados tiempo atrás cuando se enviaron a su destinatario. Asimismo, también mandó que se entregasen a las monjas de Santa María de la Contemplación dos ollas y dos cántaros, para servicio del monasterio, y que otros dos cántaros que tenía se pusiesen en su capilla de San Miguel para guardar el aceite de las lámparas. Por otro lado donó a los frailes de la Merced de Cuenca mil maravedís, para reparar el monasterio de la Fuent Santa, estableció también que se diesen determinadas prendas de vestir a ciertos frailes y $\operatorname{laicos}^{198} \mathrm{y}$, según ya se ha señalado,

196 “Item, mando a Iohan de Ocaña mi criado, por serviçios que me fiso, veynte mill maravedís e más todos los frutos deste año de la mi prestamera de Tribaldos desta dióçesis. Item, mando a Alfonso Terçeado çinco mill maravedís. Item, mando a Alfonso de Myllana ocho mill maravedís. Item, mando a Gonçalo de Myera quinse mill maravedís. Item, mando a... veynte mill maravedís y el machón de silla que tiene. Item, mando a Garçía quinse mill maravedís. Item, mando a Pedro quinse mill maravedís. Item, mando a Françisco dos mill maravedís. Item, mando [a] Ferrandico çinco mill maravedís. Item, mando a Diaguito çinco mill maravedís. Item, mando a las amas que están en casa, a cada una mill maravedís... Item, mando a Ferrando de Sanabria seys mill maravedís. Item, mando a Bartholomé de León çinco mill maravedís. Item, mando a Palomares quatro mill maravedís. Item, mando a Lope de Alcáçar quatro mill maravedís. Item, mando a Luys, el que mora en Alfaro, dies mill maravedís. Item, mando a Valdemeca quatro mill maravedís. Item, mando a Iohan Carrillo dos mill maravedís...".

197 Juan Carrillo, que había sido pariente del cardenal de origen conquense Alfonso Carrillo de Albornoz, también era titular desde 1432, entre otros beneficios, de la abadía de San Miguel de Alfaro, de patronato regio. En 1465 aparece como miembro del Consejo del príncipe don Alfonso. NOGALES RINCÓN, D., La representación religiosa de la monarquía castellano-leonesa: la capilla real (1252-1504), Tesis Doctoral, Madrid, 2009, p. 2004. Todavía vivía en 1477, pues el 25 de septiembre de este año los Reyes Católicos nombraron a Juan Pérez de Cabrera como abad de San Miguel de Alfaro, abadía a la que había renunciado Juan Carrillo alegando no poder servir dicha iglesia ni administrar correctamente sus rentas. Archivo General de Simancas, Registro General del Sello, 1477-IX, f. 114.

198 "Item, mandó que una çamarra nueva que él tenya que fuese dada a Fray Ambrosio, frayle de la horden de San Gerónymo en la Sisla de Toledo. Item, dixo e mandó que otra çamarra que agora se fasía que la acaben e fagan acabar e la paguen de sus dyneros e la den los dichos sus testamentarios graçiosa al prior general de Sant Bartolomé de Lupyana. Item, dixo e mandó que de sus byenes sea dado a la madre de Montenegro, su criado, e a la madre de Theresa de Salynas, sendas sayas e sendos mantos e sendos tavardos de paño pardillo común de Cuenca, en lymosna por serviçio de Dios". 
otorgó autorización para que el canónigo Diego de Valera y todos sus criados pudiesen enterrarse sin coste alguno en su capilla.

Finalmente, en una última adición de clásulas al testamento realizada el 10 de agosto, se incluyó una relación de personas -parientes, familiares y criados suyosque habrían de ocuparse de la crianza y cuidado de algunos de los niños abandonados de los que él se había hecho cargo:

El dicho señor chantre....mandó que fuesen embiados a su costa del a Ynés Álvares, su hermana, e a Pero Álvares, su hermano, e a Diego Álvares e a Iohan Álvares, sus sobrynos, sendos niños destos que él avya fecho criar para que los críhen e fagan bien por serviçio de Dios e por amor suyo. E que al dicho Diego de Valera que le den una niña para que la críhe e la case, e a Alfonso Terçeado su criado que le den a Calisto y a Tecla para que los críe e los case por serviçio de Dios e por amor suyo, el qual dicho Alfonso Terçeado dixo que era contento e le plasía de lo faser. E más dixo e mandó que sy alguno de sus criados quisiese a alguno de los dichos niños para criallo que ge lo diesen...

El fallecimiento de Nuño Álvarez acaeció el 13 de agosto de 1476, quedando recogido en el Necrologio-Obituario de la catedral conquense ${ }^{199}$. No obstante, el anónimo autor de la Vida del Venerable don Nuño Álvarez de Fuente Encalada, chantre e canónigo de la Santa yglesia cathedral de la noble çibdad de Cuenca, escrita según ya se ha dicho por un clérigo conquense que llegó a conocer en vida al chantre, señala erróneamente que su muerte acaeció el 14 de agosto de 1477, víspera de la fiesta de la Asunción de la Virgen, describiendo el suceso con los siguientes términos:

En el año de la Encarnaçión del nuestro redemptor Ihesu Christo de mill y quatroçientos y setenta y siete años, a catorçe días del mes de agosto de aquel año, e a las dos oras después del mediodía, en tocando la campana de las vísperas en la yglesia mayor con la solepnidad que la fiesta de la sagrada Asumpçión de Nuestra Señora la Virgen María requiere, fue el fallesçemiento deste Sancto et venerable saçerdote et doctor et ministro de la yglesia...En aqueste día fue su natal et nasçimiento para la vida eterna... ${ }^{200}$

199 “A treze días andados del mes de agosto, quasi medio día, fallesçió el venerable don Nuño Álvarez de Fuente Encalada, doctor en Decretos, chantre de la iglesia de Cuenca. Anno Domini MCCCCLXXVI. Anima eius requiescat in pace. Amen". ACC, Necrologio-Obituario, f. 26r. La muerte del chantre en agosto de 1476 también puede respaldarse con otros argumentos. Por un lado, en el testamento, redactado entre el 7 y el 10 de agosto de este año, se señala de forma explícita que Nuño Álvarez se encontraba "doliente en una cama", atendido por un físico y un cirujano. Pero probablemente el argumento más convincente lo ofrece el libro de pitancería del cabildo catedralicio correspondiente a este año de 1476, a pesar de que en el mismo faltan los folios de los meses de marzo hasta fines de septiembre. Así, consta que durante los meses de enero y febrero el chantre asistió con regularidad al menos al rezo de la hora de prima. ACC, Pitancería, 1476, ff. 2r-24v. Tras la indicada laguna de información, los datos sobre la asistencia de los canónigos a coro reaparecen a partir del sábado 28 de septiembre, pero entonces ya no figura la asistencia del chantre, sin duda porque había fallecido, prueba de lo cual es que ese mismo día, víspera de la fiesta de San Miguel, el canónigo pitancero que redactó el libro dejó constancia de que hubo "proçesión del altar de Sant Myguel a la capilla que fiso el señor chantre don Nuño Álvarez de Fuente Encalada, ay pitança de la dicha proçesión”. Ibídem, f. 25r. Y durante los meses siguientes desaparece cualquier referencia al chantre.

200 ACC, Obras Pías, leg. 315, exp. 3. La misma fecha de fallecimiento, 14 de agosto de 1477, es la que proporciona PINEDA Y HURTADO DE MENDOZA, J. de., Proles Aegidiana ..., p. 10. 
El biógrafo conquense, ya al final de su narración, esgrimiendo argumentos a favor de la santidad del chantre, vuelve a insistir en lo providencial de su muerte en la víspera de la fiesta de la Asunción (frente al día 13 de agosto que recoge el NecrologioObituario), escribiendo de forma piadosa lo siguiente sobre el modo como acaeció su muerte:

...por sus serviçios meresçió que la Virgen Nuestra Señora Santa María, reyna de los çielos, le aparesçiese con santo fyn que fuese en su vigilia de su mayor fiesta de su sagrada Asumpçión, a la ora de las vísperas, çercado de treynta e seys niños de los falladizos e de los otros cryados que servían, por todos çincuenta con sus candelas ençendidas, cada uno en su lugar orando e llorando con lágrymas de mucho amor... E asy estando çercado destos niños, casi a la hora que con ellos se solía gozar e repartirles el pan bendito, abraçado con la cruz e resçebidos los sacramentos, e seyendo presentes algunos canónigos de aquella yglesia, dio el espíritu a su façedor en olor de suavidad, el qual olor allí todos sintieron palpablemente, e piadosamente creyeron segund las señales que se fizieron en este tránsito que hera hombre justo e que Dios lo llevava para su gloria en compañía del Santo arcángel, en cuya capilla fue sepultado...

Y, asimismo, este biógrafo también nos dice que el día de su entierro en la capilla de San Miguel, al que supuestamente asistió, predicó un excelente maestro en Teología -cuyo nombre no proporciona- que en su discurso ensalzó todas las virtudes cristianas del fallecido.

\section{LA MEMORIA HISTÓRICA DE NUÑO ÁLVAREZ}

La figura del chantre Nuño Álvarez, debido sobre todo a la dimensión específica de su singular religiosidad, dejó una huella perdurable durante varios siglos en la memoria histórica del obispado conquense y, en menor medida, del colegio de San Clemente de Bolonia, y poco tiempo después de su muerte comenzaron a aparecer algunas de sus primeras biografías.

La ya tantas veces aludida primera biografía del chantre, Vida del Venerable don Nuño Álvarez de Fuente Encalada, chantre e canónigo de la Santa Yglesia cathedral de la noble çibdad de Cuenca, una obra manuscrita que se conserva en el Archivo Catedralicio de Cuenca ${ }^{201}$, debió de escribirse hacia fines del siglo XV o comienzos de la centuria siguiente, pues su anónimo autor afirma haber sido tiempo atrás un mozo de capilla que ayudaba al chantre en la misa, y haber estado presente en su lecho de muerte ${ }^{202}$, ofreciendo datos diversos que corroboran que, en efecto, conoció a nuestro personaje, si bien nos presentará su biografía revestida de múltiples

${ }^{201}$ ACC, Obras Pías, leg. 315, exp. 3. Una copia resumida de esta biografía, bajo el título Esta es la vida de aquel gran siervo de Dios don Nuño Álvarez, chantre y canónigo que fue en la Santa Yglesia de Cuenca, se conserva en la biblioteca de la Real Academia de la Historia, colección Salazar y Castro, L-4, ff. 1r-4v. Dicha copia lleva datación al final: en Cuenca, a 18 de marzo de $157 \ldots$ (el último número del año es ilegible).

202 “...las postrimeras palabras que dixo fueron al su moço de capilla que le solía ayudar a la misa, diziéndole lo que devía de façer siguiendo la virtud, el qual como fiel siervo escrivió este memorial de su vida fielmente al honor e gloria de Dios...". ACC, Obras Pías, leg. 315, exp. 3. 
elementos de idealización religiosa, a modo de panegírico. Sin duda su autor era un clérigo conquense, quizá miembro del cabildo o clero catedralicio en el momento de redactarse la obra.

En todo caso la escritura de esta pequeña obrita biográfica debe situarse en el contexto ideológico y espiritual de la reforma del clero que, bajo el amparo regio, había venido desarrollándose en la corona de Castilla durante el siglo XV, y, a nivel local, en unos momentos en la historia de la iglesia conquense de contundente rechazo por parte del clero de la diócesis hacia algunos obispos absentistas, extranjeros, que fueron titulares de la mitra durante muy largos períodos, como es el caso del los cardenales Antonio Jacobo de Veneris (1469-1479) y Rafael Riario (1493-1518). No en vano fue durante estos pontificados cuando comenzó a desarrollarse el culto local hacia quien había sido segundo obispo de la diócesis, San Julián (1198-1208), culto que ya aparece claramente documentado en el último tercio del siglo XV, cuando el cabildo catedralicio intentaba fomentar la veneración como santo patrono de su antiguo obispo, en cuyo honor, al menos desde 1471, el cabildo celebraba una fiesta anual con procesión todos los 28 de enero, y sobre el cual se desarrolló en la memoria histórica local, a nivel catedralicio, una imagen idealizada que lo presentaba como perfecto modelo de prelado casto y humilde, residente en su diócesis y plenamente entregado a su labor pastoral y a obras de caridad, a la vez que se atribuían a su sepultura en la catedral conquense efectos taumatúrgicos y milagrosos, lo que culminaría, en la noche del 17 de enero de 1518, con la solemne apertura de su viejo sepulcro medieval y el hallazgo de su cuerpo incorrupto, acontecimiento al que siguió, durante ese año, una fugaz corriente de peregrinación diocesana hacia su tumba, que daría paso durante los años siguientes a la institucionalización ceremonial del culto al santo ${ }^{203}$.

Lo que aquí importa destacar es que fue en este contexto sociocultural y espiritual en el que la figura del chantre Nuño Álvarez, aunque en un nivel inferior al de San Julián, adquirió pronto un puesto de relieve dentro de la memoria histórica local, que también le recordará como modelo de eclesiástico humilde, casto, estricto cumplidor de sus obligaciones religiosas, siempre residente en su iglesia y entregado fervientemente a labores de caridad, todo lo cual contribuyó sin duda a que tras su muerte los círculos eclesiásticos locales tratasen de impulsar una cierta veneración hacia su figura, llegando incluso a defender su beatitud o santidad en pequeños relatos biográficos como los que ahora nos ocupan, a través de los cuales la historiografía se ponía al servicio de la tradición eclesiástica diocesana. En este sentido no es en absoluto casual que el chantre y San Julián aparezcan unidos en una de las primeras biografías conocidas de este último, la Vida y milagros del glorioso confessor San Julián, segundo obispo de Cuenca...Ansí mismo la vida de don Nuño Álvarez, chantre y canónigo de la Santa Iglesia de Cuenca, de Francisco Escudero, publicada en Toledo en 1589.

Volviendo ahora a la Vida del Venerable don Nuño Álvarez de Fuente Encalada, chantre e canónigo de la Santa Yglesia cathedral de la noble çibdad de Cuenca, en cuyo preámbulo también se menciona al obispo San Julián, hay que destacar primeramente que su autor, además de haber conocido en vida al chantre, demuestra ser un clérigo relativamente docto, versado en latín y conocedor de la Biblia y de la patrís-

${ }^{203}$ Sobre todo ello puede verse el amplio y bien documentado estudio de JIMÉNEZ MONTESERÍN, M., Vere Pater Pauperum. El culto a san Julián en Cuenca, Cuenca, 1999. 
tica. Así, a medida que se nos van narrando los hechos más destacados de la vida del chantre, como fundamento y apoyo de sus afirmaciones el autor recoge citas bíblicas del Eclesiastés, Eclesiástico, Sabiduría, Salmos, Proverbios y Evangelio de San Mateo, así como de San Jerónimo y de los sermones de San Agustín.

El preámbulo introductorio de la obra gira en torno a la idea de la muerte como nacimiento para la vida eterna, destacando la necesidad de alabar y recordar a los hombres justos y virtuosos que merecen la consideración de santos, aunque su canonización todavía no se haya producido, tomando su vida como ejemplo a seguir. Los fundamentos doctrinales que el autor utiliza como respaldo de estos argumentos proceden de los Libros sapienciales, concretamente del Eclesiastés, del Eclesiástico y de los Salmos:

...A catorçe días del mes de agosto de aquel año e a las dos oras después del mediodía, en tocando la campana de las vísperas en la yglesia mayor con la solepnidad que la fiesta de la sagrada Asumpçión de nuestra Señora la Virgen María requiere, fue el fallesçimiento deste santo e venerable saçerdote e doctor e ministro de la yglesia... En aqueste día fue su natal e nasçimiento para la vida eterna. Esto es porque el sabio Salomón dize dies mortis dies nativitatis ${ }^{204}$, el día de la muerte es día del naçimiento. $\mathrm{Y}$ en el Eclesiástico, en el capítulo XLIIII, dize laudemus viros gloriosos ${ }^{205}$, commo quien dize lauda post morte magnum tua post consumacione quia vos populli vos Dei calita sua, que quiere dezir alabemos los varones gloriosos y después de su fyn y consumaçión dygamos sus magnifiçençias, que la boz del pueblo es boz de Dios...E por estos documentos e por otros, como testigo de vista que fuy presente a este santo nasçimiento recontaré su vyda para edificaçión y exemplo de los que tovieren semejantes dignidades en aquella yglesia y en otras, e para otros que fueron sus parientes o familiares o criados, los quales oyendo sus obras sigan sus pisadas, agradesçiendo a Dios e a él tan santos exemplos commo les dexó en perpetua heredad...e en el salmo dize in memoria eterna erit justus ${ }^{206}$, que quiere dezir en memoria perpetua será el justo. No se diga reprehensión porque escriva esta vida e obras santas diziendo que no está escripto su nombre en el catálogo de los santos ny por la santa Yglesia romana canoniçado, porque muchos santos padres que moraron en los yermos, cuyas vidas están escritas y se leen para buen enxemplo, segund lo escrive san Jerónymo, no están canonizados o por falta de soliçitadores o por muchedumbre, por la qual se faze la fiesta de Todos los Santos, e aun en nuestros tiempos fue sant Julián obispo desta yglesia de Cuenca, el qual se mantenía del trabajo de sus manos secretamente, y en Salamanca fray Juan de Sahagún...e otros cuyas vidas e santas obras están escriptas para buen enxemplo de remedar, e así escrivo yo aquestas e la canonizaçión de los tales piadosamente se crece en el cielo, e que en la tierra se fará en sus tiempos oportunos quando plaga al Señor ${ }^{207}$.

Un elemento muy relevante en esta primera biografia de Nuño Álvarez, según ya se ha señalado, es el que viene dado por la insistencia del anónimo autor en vincular

${ }^{204}$ En el Eclesiastés, uno de los libros más citados de la Biblia, de autor desconocido aunque atribuido tradicionalmente al rey Salomón, se dice: Melius est nomen bonum quam unguenta pretiosa et dies mortis die nativitatis (es mejor buena fama que buen perfume, y el día de la muerte que el del nacimiento). Eclesiastés, $7: 1$.

\footnotetext{
205 Laudemus viros gloriosos. Eclesiástico, 44:1.

206 In memoria aeterna erit justus. Salmos, 112 (111): 6.

207 ACC, Obras Pías, leg. 315, exp. 3.
} 
al chantre con el linaje de los Osorio, marqueses de Astorga ${ }^{208}$. Dada la veneración que desde poco después de su muerte despertó la figura de Nuño Álvarez en la memoria histórica de la diócesis conquense, y habida cuenta de sus seguramente modestos orígenes sociales, resultaba necesario garantizarle unos ilustres y fuera de toda duda nobilísimos orígenes familiares, para lo cual la solución que se consideró más conveniente fue su vinculación con el linaje de los Osorio. Además a fines del siglo XV, aunque todavía tímidamente, el problema de la "limpieza de sangre" comenzaba a hacer acto de presencia en los cabildos eclesiásticos seculares españoles, y de forma más clara en el colegio de San Clemente de Bolonia ${ }^{209}$, explicándose así mejor en este contexto social e ideológico el deseo de que no pudiese haber ninguna duda ni sospecha en torno a los nobles y legítimos orígenes de determinados eclesiásticos y colegiales cuya figura se deseaba ensalzar.

Así, este biógrafo conquense, buscando enaltecer aún más los orígenes y ancestros de Nuño Álvarez, fue sin duda el primero que estuvo también interesado en vincular a su biografiado con nada menos que Pedro Fernández, primer maestre de la orden de Santiago, que ya en el siglo XVI era denominado por algunos autores, entre ellos el nuestro, como Pedro Fernández de Fuente Encalada, por su supuesto nacimiento en esta aldea del obispado de Astorga, si bien hoy sabemos que en realidad este Pedro Fernández fue natural de la villa de Hita, situada por entonces, a comienzos del siglo XII, en territorio fronterizo ${ }^{210}$. Así, nuestro autor señala explícitamente que "en esta Fuente Encalada nasçió el primer maestre que ovo en Castilla de la horden de Santiago, el qual se llamó don Pero Fernández de Fuente Encalada, el qual fizo virtudes e obras piadosas a la horden para perseguyr e vençer a los moros ynfieles que a la sazón fueron en Castilla, e fizo otras muchas proeças que se recuentan en su estoria, e así fueron estos dos santos varones de un mismo lugar e parentela". Así, el discurso historiográfico de este primer biógrafo está claramente orientado a dejar bien claros los nobles y cristianísimos orígenes de Nuño Álvarez.

Tras el preámbulo introductorio y el enaltecimiento de los orígenes familiares del chantre, y después de dedicar algunas líneas a su juventud y a su etapa de colegial en San Clemente de Bolonia, el resto de la obra está centrada en su largo período de permanencia en la iglesia de Cuenca, hasta su muerte, dedicándose a ensalzar su humildad, su castidad, sus ayunos, su extrema devoción cristiana, sus constantes limosnas y acciones caritativas hacia los pobres, el riguroso cumplimiento de sus obligaciones religiosas en la iglesia conquense y otras virtudes que, en definitiva, vendrían a avalar la santidad de Nuño Álvarez. Sobre gran parte de todo ello ya se ha hablado en páginas anteriores. El carácter panegírico del discurso queda patente

208 Señala el biógrafo que "fue de legítimo matrimonio e de linage de nobles cavalleros de la casa que dezyan del conde de Trastámara, que agora se dize marqués de Astorga”. ACC, Obras Pías, leg. 315, exp. 3.

209 Ya en 1482 se determinó que no se adminiese como colegiales a los oriundos de Sevilla si no atestiguaban ser cristianos viejos, y muy pronto este requisito pasó a exigirse a todo candidato a colegial, permaneciendo vigente durante los siglos del Antiguo Régimen. PÉREZ MARTÍN, A., Proles Aegidiana. I. Introducción..., pp. 31 y 48. Sobre todo ello puede verse el trabajo de CUART MONER, B., Colegiales mayores y limpieza de sangre durante la Edad Moderna. El estatuto de San Clemente de Bolonia (siglos XVXIX), Salamanca, 1991.

210 CANAL SÁNCHEZ-PAGÍN, J. M., "Don Pedro Fernández, primer maestre de la Orden militar de Santiago. Su familia. Su vida", Anuario de Estudios Medievales, 14 (1984), pp. 49 y 53. 
incluso cuando se nos habla de su infancia y primera juventud, al señalarse que "este chantre seyendo de tierna hedad, enseñado de sus padres en santas costumbres... en aquellos sus tiernos años començó a ayunar los lunes e viernes de cada semana a pan y agua, e los miércoles e sábados a conducho cuaresmal desde que cumplió la hedad de doze años... E siempre cresçía en él su temor syguyendo el documento del profeta sapiençiae timor domini, psalmo CX, el comienço de la sabyduría es el temor del Señor..."211. Por otro lado, al destacarse la humildad de su forma de vida y de su enterramiento, el biógrafo señala que lo hizo "reputando ser menor que sus siervos, por complir aquello del Evangelio que dize qui maior est vestrorum fiat sic ut minister, el que es mayor de vosotros fágase commo menor syrviente" ${ }^{212}$. Respecto a sus particulares acciones de caridad hacia los niños falladizos se nos dize que muchos días les reunía "e demandávales cuenta de sus vidas a cada uno con mucho gozo, e dávales çiertos panes delgados...e razonava y estava solo con ellos commo uno dellos por complir lo del Evangelio que dize... si no soys fechos como niños no entraréis en el reyno de los çielos" 13 . Y entre los argumentos que se esgrimen en defensa de su santidad, no se dudará incluso en atribuirle ciertos milagros de claras connotaciones evangélicas, como son la curación de una monja endemoniada y la multiplicación en época de carestía de las fanegas del trigo con que alimentaba a los niños que eran abandonados ${ }^{214}$.

Con posterioridad a la obra recién descrita se publicarían otras breves biografías sobre Nuño Álvarez, bien de forma monográfica o formando parte de trabajos sobre el colegio de San Clemente de Bolonia. Ejemplos de ello son la Vida del beato Nuño Osorio (Bolonia, 1630), de Juan Malo de Briones, que también fue colegial en San Clemente; la Vida del bienaventurado sierbo de Dios Nuño Álvarez de Osorio, colegial que fue del insigne y mayor Colegio de los Españoles (Bolonia, 1630), de Bredes de Mazo; y la ya citada obra Compendio de la nobilíssima fundación y privilegios del Colegio mayor de señor San Clemente de los españoles de Bolonia ...y vidas y gloriosas muertes de Sr. San Pedro de Arbues y venerable Nuño Álvarez Ossorio, digníssimos alumnos (Madrid, 1695), de Salvador Silvestre de Velasco y Herrera ${ }^{215}$, presbítero y colegial en Bolonia en el siglo XVII, libros todos ellos centrados en en-

211 Salmos, 111 (110): 10 .

212 "El primero entre vosotros será vuestro servidor". Mateo, 23:11.

213 "En verdad os digo que, si no os convertís y os hacéis como niños, no entraréis en el reino de los cielos". Mateo, 18:3.

${ }^{214}$ A estos milagros se alude en la copia de la biografía del chantre conservada en la Real Academia de la Historia. Por un lado se dice que "una monja que estava endemoniada fue libre por los ruegos de este siervo de Dios". Y por otra parte se señala que en cierta ocasión, en época de carestía, habiendo el chantre llevado a Cuenca toda su renta del pan de ese año, "un día vinieron ciertas amas de los niños y lleváronse todo el trigo que havía traydo, y después vinieron otras postreras a pedille trigo, y como él les dixo que no havía más trigo lloravan las tristes mugeres amargamente pidiéndole que le pagase su trabajo, y el varón santo viéndolas assí afligidas començó a llorar con ellas y hizo mirar otra vez las troxes y hallaron seis fanegas de trigo para seis mugeres que eran las que lloravan, y afirmaban los mayordomos de don Nuño Álvarez que era la tertia parte mayor el gasto que tenía que los fructos que tenía de su renta". Real Academia de la Historia, colección Salazar y Castro, L-4, f. 4 r.

${ }^{215}$ En esta última obra, el capítulo XII lleva por título "Vida del venerable Nuño Álvarez Ossorio, colegial del mismo colegio mayor, chantre de Cuenca y arçobispo electo de Santiago", SILVESTRE DE VELASCO Y HERRERA, S., op. cit., pp. 192-200. 
salzar los nobilísimos orígenes -no se pone en duda su legítima pertenencia al linaje Osorio-, virtudes, extrema humildad, castidad y acciones caritativas y de mecenazgo del chantre.

La publicación de estas obras, fundamentalmente las dos primeras, ha de situarse en el contexto de las diligencias que en la década de los años treinta del siglo XVII estaba realizando el cabildo catedralicio conquense para que desde la Santa Sede se procediese a la beatificación de Nuño Álvarez. En efecto, en abril de 1631, en época del obispo Enrique Pimentel, desde el cabildo se realizaban esfuerzos por difundir la idea de que Nuño Álvarez Osorio de Fuente Encalada había muerto, según ellos, en el año 1477, con fama de santidad, y que "sus heroycas y excelentes virtudes se han venerado continuamente no sólo en la dicha santa iglesia, ciudad y obispado de Cuenca, sino también en el obispado de Astorga su patria y en el Collegio de Bolonia donde fue collegial, según se anuncia en las historias de su vida por muchos y graves autores...por tradición es tenido y venerado en el dicho collegio y en aquellas partes por beato...". De este modo, el 15 de abril del mencionado año de 1631, a las diez de la noche, a puerta cerrada dentro de la catedral y en un acto de gran contenido ritual que se asemeja en muchos aspectos al que un siglo atrás había tenido lugar ante la tumba de San Julián, se procedió a abrir el sepulcro donde estaba enterrado el chantre Nuño Álvarez, en la capilla de San Miguel. El acto estuvo presidido por el obispo Enrique Pimentel, y asistieron entre otros el deán Claudio Pimentel; Diego de Veancos Salcedo, arcediano de Cuenca; Francisco de Alarcón, maestrescuela; Antonio de Anaya y Sandoval, abad de Santiago; Diego Mazo de la Vega, arcipreste; Fernando de la Mesa Carvajal, provisor general del obispado; y Pedro Zapata, prior y canónigo obrero. Según el auto en que dicho acto quedó recogido, la sepultura se encontraba cubierta por una lápida de pizarra negra en la que a duras penas se veía el nombre del fallecido y, supuestamente, los escudos de armas de la casa de los marqueses de Astorga -cosa extraña, que para nada coincide con los deseos sobre su humilde forma de enterramiento expresados por el chantre en su testamento-, señalándose que todas estas inscripciones se encontraban "casi borradas por la injuria de los tiempos". En la tumba se encontraron los huesos y al observar detenidamente el cráneo les "pareció cosa rara y prodigiosa que los dientes altos y bajos de la boca estaban cabales y asientan unos en los otros, y están tan frescos, blancos e incorruptos como lo pueden estar en la boca de un cuerpo mozo, fuerte, sano y robusto...". A continuación se procedió a colocar los huesos en una caja y el propio obispo, acompañado por los presentes, los colocó provisionalmente junto al sagrario de la catedral, para que estuviesen en un lugar más digno.

Algunos días después, el 22 de abril, el obispo mandó que en la capilla de San Miguel se construyese un nicho decente para que los huesos del chantre, a modo de reliquias, pudiesen ser venerados adecuadamente mientras desde el cabildo se efectuaban trámites ante la Santa Sede para tratar de conseguir la beatificación y, en su caso, canonización de Nuño Álvarez. Quien actuó como procurador del cabildo catedralicio en dichos trámites fue precisamente el mencionado Juan Malo de Briones, colegial de San Clemente y autor de una biografía de Nuño Álvarez. Dicho Juan Malo también realizaría las gestiones oportunas para que se obtuviese una copia fidedigna de cierto retrato de Nuño Álvarez que al parecer se conservaba en el altar de 
la capilla del colegio de San Clemente, con la intención de colocar dicho retrato en la capilla de San Miguel, y de hecho sabemos que la copia del retrato llegó a Cuenca el 28 de septiembre de 1633, siendo entregada al cabildo el uno de octubre ${ }^{216}$. Es de suponer que prosiguieron las diligencias para la beatificación de Nuño Álvarez, si bien desconocemos su desarrollo concreto, tratándose en todo caso de una cuestión que ya no será abordada en el presente estudio.

\section{CONCLUSIÓN}

A lo largo de las páginas precedentes se ha analizado la figura de Nuño Álvarez de Fuente Encalada, un clérigo castellano del siglo XV cuya biografía presenta rasgos ciertamente singulares. De orígenes sociales probablemente modestos, la primera etapa de su carrera eclesiástica, antes de su llegada a Cuenca, se desarrolló al amparo de la protección que le otorgó sobre todo el obispo conquense Álvaro de Isorna, de quien era familiar. Es esta la etapa de su participación, acompañando a la embajada castellana y como auxiliar de Isorna, en el concilio de Basilea, y de sus largos años de estudio en la universidad de Bolonia, residiendo en el colegio de San Clemente, hasta obtener en 1438 el Doctorado en Derecho canónico.

Poco tiempo después se estableció en la iglesia conquense, donde también por mediación del obispo Isorna obtuvo la dignidad de chantre con canonjía en el cabildo catedralicio, residiendo casi permanentemente en Cuenca y como titular de estos beneficios hasta su muerte en 1476. Así, durante más de tres décadas, y ocupando un puesto que le situaba en lo alto de la jerarquía social y eclesiástica de la ciudad, desempeñó múltiples y diversas tareas cultuales y administrativas al servicio de la iglesia conquense, revistiendo un particular relieve la donación que hizo en 1450 a favor del cabildo catedralicio de su valiosa biblioteca personal, de contenido fundamentalmente jurídico y teológico, reflejo de sus inquietudes intelectuales. Junto a éstas, destacan la peculiar espiritualidad del personaje, sus preocupaciones religiosas y las actividades caritativas y de mecenazgo que, dada su gran solvencia económica, pudo llevar a cabo; de entre estas últimas tuvieron un especial relieve su constante ayuda para criar a los "niños falladizos" que eran abandonados al nacer, y la fundación y dotación que llevó a cabo del monasterio de monjas benedictinas de Santa María de la Contemplación, en la misma ciudad de Cuenca.

Por todas estas razones tras morir comenzaría a ser objeto de recuerdo y veneración en la iglesia conquense, dejando una huella perdurable durante varios siglos en la memoria histórica del obispado e incluso en el colegio de San Clemente de Bolonia, lo que explica también que poco tiempo después de su muerte comenzasen a aparecer algunas de sus primeras biografías, en las que, además de enaltecerse sus orígenes familiares, se le presenta como modelo de eclesiástico humilde, casto, estricto cumplidor de sus obligaciones religiosas, siempre residente en su iglesia y entregado fervientemente a labores de caridad, defendiéndose incluso su beatitud o santidad. Esta veneración local hacia el personaje habría de culminar en 1631, cuando se desenterraron solemnemente sus restos en la capilla de San Miguel de la

${ }^{216}$ ACC, Obras Pías, leg. 315, exp. 2/7. 
catedral, se colocaron en un nuevo nicho y se pusieron en marcha gestiones ante la Santa Sede para tratar de conseguir su beatificación.

\section{APÉNDICE DOCUMENTAL}

1451, agosto, 19. Pareja.

Fray Lope de Barrientos, obispo de Cuenca, otorga comisión a su vicario general Sancho Ruiz, arcipreste de Olmedo, para anejar dos prestameras situadas en los lugares de Fuentes y Chillarón (de Pareja) al monasterio de Santa María de la Contemplación de Cuenca, prestameras que pertenecian al chantre Nuño Álvarez de Fuente Encalada y con las que éste deseaba fundar una capellanía en el monasterio.

-AHPC, Hacienda, 141, Clero/Benitas nº 4, exp. 7 (olim Desamortización, leg. 511).

Don Lope de Barrientos, por la graçia de Dios e de la Santa iglesia de Roma obispo de Cuenca, confesor del rey nuestro sennor e del su consejo, a vos el honrrado Sancho Ruys, arçipreste de Olmedo, canónigo en la nuestra iglesia de Cuenca, nuestro vicario general, salud e bendiçión. Sepades que el honrrado don Nunno Álvares de Fuente Encalada, chantre en la dicha nuestra iglesia, nos enbió faser relaçión que él, movido con buena entinçión e desto, e por acresçentar la renta al monesterio de Nuestra Sennora Santa María de la Contenplaçión de la çibdad de Cuenca, quería anexarle dos prestameras suyas, una que tiene en Fuentes e otra en el nuestro logar Chillarón, para faser dellas una capellanía, sobre lo qual nos enbió pedir por merçed quesiemos enbiar nuestra comisión para una persona de nuestra iglesia para que, a consentimiento del deán e cabildo de la dicha nuestra iglesia, pudiese faser la dicha anexaçión. Por ende, acatando vuestra discreçión e legalidad e çiençia, por la presente vos cometemos esta causa para que podades faser e fagades en ello todo lo que nos podriamos faser presente seyendo, a consentimiento del dicho deán e cabildo de la dicha nuestra iglesia, para lo qual todo e cada cosa e parte dello vos cometemos nuestras vistas e vos damos nuestro poder conplido por esta ves. En testimonio de lo qual mandamos dar esta nuestra carta firmada de nuestro nonbre e sellada con nuestro sello, dada en la nuestra villa de Pareja, dies e nueve días del mes de agosto, anno del nasçimiento del Nuestro Sennor Ihesu Chripto de mill quatroçientos e çinquenta e un annos.

Yo Rodrigo de Çisneros, secretario del dicho sennor obispo la fis escrevir por su mandado.

[En el centro, firma autógrafa del obispo Barrientos:] Dominus Lupus, episcopus conchensis. 
1451, diciembre, 18. Chillarón de Pareja.

Pascual de Torralba, como procurador de María González, priora del monasterio de Santa María de la Contemplación de Cuenca, toma posesión de la ración prestamera que el chantre Nuño Álvarez tenía en la iglesia de Santa María de Chillarón, a la que éste había renunciado en favor del monasterio para establecer una capellanía.

-AHPC, Hacienda, 141, Clero/Benitas no 4, exp. 6 (olim Desamortización, leg. 511).

In Dei Nomine, Amen. Sepan quantos este público instrumento de posesión vieren commo en Chillarón, logar de la villa de Pareja, en dies e ocho días del mes de desienbre del anno del nasçimiento del Nuestro Salvador Ihesu Chripto de mill e quatrocientos e çinquenta e un annos, ante las puertas de la iglesia de Santa María del dicho lugar Chillarón, e en presençia de mí, Pero Ruys de Pareja, notario público, e de los testigos infraescriptos, peresçió hi presente Pascual de Torralva, familiar e criado del honrrado Alfonso Garçía de Sant Felises, canónigo e en [sic] la iglesia de Cuenca e visitador general en todo el dicho obispado de Cuenca, commo procurador bastante que se mostró de la devota religiosa María Gonçáles, priora del monesterio de Santa María de la Contenplaçión de la çibdat de Cuenca, e de las otras monjas e duennas profesas del dicho monesterio, e presentó e leer fiso por mí, dicho notario, ante Pero Martínes de Chillarón, clérigo que presente estava, una fee de notario público, el thenor de la qual es este que se sigue e dise ansy.

Yo Gonçalo Yannes, raçionero en la iglesia de Cuenca, notario apostólico, fago fee en commo el chantre de la iglesia de Cuenca renunçió en cabillo las sus prestameras que tenía e poseya en la iglesia perochial de Fuentes, aldea de la çibdat de Cuenca, e en la iglesia perrochial de Chillarón, aldea de Pareja, en las manos del arçipreste de Olmedo, vicario general, el qual, con consentimiento de los sennores deán e cabillo de la dicha iglesia de Cuenca, anexó las dichas dos prestameras al monesteryo de Sennora Santa Marya de la Contenplaçión, para dos capellanías perpetuas que se canten en el dicho monesteryo, la qual dicha anexaçión fiso el dicho arçipreste segunt dicho es por poderyo espeçial que él tenía del sennor obispo de Cuenca, segunt que más largamente lo yo daré signado en forma quando yo fuere requerido, con el anno e día e testigos. G. Iohannis, notarius appostolicus.

E leyda la dicha escriptura en presençia del dicho Pero Martínes, clérigo, el dicho Pascual de Torralva, procurador, en nonbre de sus partes dixo que pidía e pidió al dicho Pero Martínes, clérigo que presente estava, que por virtud de la dicha escriptura ante él presentada lo pusiese en la posesión real de la raçión prestamera que en la dicha iglesia de Chillaron pertenesçía al dicho sennor chantre de la iglesia de Cuenca, segunt por la escriptura susodicha se contiene, e que si así lo fisiese que farya bien e lo que de derecho era tenido, en otra manera que protestava e protestó de se quexar del a quien de derecho deviese. E luego el dicho Pero Martínes, clérigo, dixo que estava presto a faser lo que con derecho deviese e, que non perturbando su derecho a persona alguna, tomó por la mano al dicho Pascual de Torralva, procurador en nonbre de su parte, e metiolo dentro en la dicha iglesia, e en sennal de possesión entregole la 
llave de la puerta de la dicha iglesia e un libro missal, e el dicho Pascual de Torralva, procurador, en sennal de posisión abrió e çerró el dicho libro e çerró e abrió las puertas de la dicha iglesia, e dixo que, en nonbre de las dichas sus partes, que se tenía e tovo por contento de la dicha posesión. E luego el dicho Pero Martínes, clérigo, dixo que mandava e mandó a todos los vesinos e moradores del dicho lugar Chillarón, e dende a todas las otras personas a quien el presente negoçio atannía o atanner podría, que recudiesen e fisiesen recodir al dicho Pascual de Torralva, en nonbre de las dichas sus partes, con todos los frutos, rentas e derechos a la dicha raçión prestamera pertenesçientes en el dicho lugar Chillarón, en la mejor forma e manera que él podía e de derecho devía. E el dicho Pascual de Torralva, procurador, en nonbre de su parte dixo que pidía e pidió a mí dicho notario que ge lo diese por testimonio, para guarda de su derecho, todo lo susodicho en commo avía pasado, de lo qual todo fueron testigos presentes a todo lo susodicho Mygell Sánches de Córdova, e Pero Gonçáles, sacristán, e Pero Martínes, fijo de Pero Martínes, vesinos del dicho lugar Chillarón, e yo Pero Ruys, notario, e otros. Fecho día e mes e anno e lugar susodichos. E yo Pero Ruys de Pareja, notario público en todo el obispado de Cuenca a merçed de my sennor don Lope de Barrientos, por la graçia de Dios obispo de Cuenca, e por la su actoridat episcopal, presente fui e, segunt que ante my e ante los dichos testigos pasó, esta carta de posessión por otro fise escrevir, seyendo yo occupado por otros negoçios, e en fyn de todo fise aquí este myo signo en testimonio.

1476, agosto, 7-10. Cuenca.

"Testamento que fizo el venerable e çircunspecto varón don Nuño Álvarez de Fuente Encalada, doctor en Decretos, chantre e canónigo en la iglesia de Cuenca".

-ACC, Obras Pías, leg. 315, exp. 2/1. Posiblemente se trate del original del testamento. Hay otras copias posteriores en el mismo legajo.

In nomine patris, et filiy et spiritus sancti, Amen, tres personas en una esençia. Manyfiesta cosa es segund dise santo Augostyni la muerte ser muy çierta a la hora della, e el logar y el modo e estado della seer a todos muy ynçiertos, e muchas veses acaesçen las muertes ser súbitas e otras vezes venyr grand fiebre e frenesçia e otras pasiones e dolores a la natura humana, por las [qua]les las personas están atormentadas e los sentydos están ocu[1ta]dos e agravyados por causa de las pasiones e dolores de la muerte, e el entendimyento está turbado e ofuscado e non lybre para disponer las cosas que convyene a servyçio de nuestro señor Dios e a salud de las ánymas, e por tanto toda persona discreta debe faser su testamento en tiempo de la prosperidad e sanydad asy del ányma commo de la persona e del entendimyento e de los sentydos, porque pueda faser juysio e sentençia e testamento o disposiçión yntegro e recto e justo a servyçio de Dios e salud de su ányma. E por ende yo Nuño Álvares de Fuente Encalada, chantre de la yglesia de Cuenca, aunque yndigno de lybre en tiempo de la sanydad e prosperydad de my persona e del entendimyento e sentydos, quales me los quiso nuestro señor Dios dar, de faser my testamento, que más verdaderamente 
puede ser dicho juysio e disposiçión general e espeçial de las cosas que después de mi muerte se han de faser, que en el tiempo de my vyda non las compliere, e porque los clérigos e benefiçiados e personas en dignidades constituydas, e mayormente los que tienen cura de ánymas, non pueden testar segund la verdadera opynión de los doctores juristas modernos, la qual siempre me plogó e la tengo por más jurídica e verdadera que la contraria, e la postrimera voluntad e disposiçión de los clérigos segund la dicha opynión ha de ser por vya de legados o mandas, desencargando sus conçiençias e satisfasiendo de las cosas de que han tenydo e tienen cargo, e mandando faser por sus ánymas algunos sufragios para redem[ir] las penas del purgatorio, porque nuestro señor Dios quyera a[ver miseri]cordia de las ánymas dellos e las quiera perdonar de los [...]gos que tovyeron en esta presente vyda, asy de rogar por el pueblo christiano e por las ánymas de los logares e yglesias de que fueron benefiçiados, commo por non destribuyr los frutos e rentas de los benefiçios que tovyeron en pobres e en las otras obras pyas a que son obligados segund derecho, e por non desyr bien e con entençión e devoçión las horas canónicas e ofiçio dyvinal segund que los derechos mandan, e por aver expendidos los tiempos e hedades de la adolesçençia e jouventud e veges en vanydades e locuras e pompas del mundo, dándose a viçios e pecados e quitándose de las virtudes e del servyçio de nuestro señor Dios, e nemyne acusando estas cosas sobredichas sean dichas por my, en el qual fueron e son muchos más viçios e pecados e fablas e defectos que yo podría desyr e pensar, de los quales me acuso manyfiestamente e me arrepyento e digo my culpa averlos fecho, e demandando a my señor Ihesu Christo perdón, que le plega de aver mysericordia con my ányma, pues él la crió e redimyó por la su santysima pasión, la quiera levar a la su santa gloria, e segund dise Sant Bernaldo que aunque le pertenesca en dos maneras el reyno çelestial, asy por iure hereditario commo por los méritos de su pasión, que le plega de ser contento con el un derecho, convyene a saber iure hereditario, e por virtud e méritos de su santysima pasión le plega de me faser coherede e partyçipe de su gloria e reyno çelestial. Amén.

Primeramente encomyendo mi ányma a nuestro señor Dios padre, e fijo e spiritu santo, tres personas en una esençia, que pues la creó de nihilo e la redimyó nuestro señor Ihesuchristo por la su sagrada pasión la quiera levar al su santo reyno e la collocar con los sus santos por la su grand misericordia e piedad.

Item, mando que mi cuerpo sea enterrado en la mi capilla que yo fise en la iglesia catredal, en prinçipio de la dicha capilla ante el altar de nuestra señora Santa María, en la qual sepultura non se sepulte otra persona alguna. E mando que non sea fecha cama alguna ni otra pompa, salvo que me pongan en un atahúd en tierra, e con el dicho atahúd e hornamentos saçerdotales e mysa me entierren. E que me fagan trese çirios a honor e reverençia de nuestro señor Ihesuchristo e de sus dose apóstoles, e cada çirio de una libra, e estos trese çirios que estén fixos e ardan en quanto duraren los ofiçios e misas, e más fagan otros dose çirios para andar por los altares adonde se dixieren las misas e ofiçios, e se fagan tres antorchas cada una de seys lybras a honor e reverençia de la santa Trenydad, e que ardan con los dichos trese çirios en quanto duraren las misas e ofiçios, e que non me lleven en andas de mi casa salvo en el dicho atahúd, e non me fagan cama en la iglesia. E mando e hordeno que los señores deán e cabyldo fagan [...] ofiçios e misa e digan e canten nueve leçiones, e el día siguiente 
misa de nuestra señora Santa María, e que sea la postrimera misa con la qual me entierren. E los clérigos de la çibdad que fagan e canten ofiçios complidos e misa que sea de la Trenydad, e los frayles de Sant Françisco que fagan e canten ofiçios complydos e digan la mysa de la Nativydad, e los frayles de nuestra señora de la Merçed que fagan ofiçios complydos e canten la misa de Santis Spiritus, e los capellanes de la iglesia mayor fagan ofiçios complydos e canten la misa de San Miguell, e los canónigos extravagantes fagan ofiçios complydos e canten la misa de réquiem. E todos estos ofiçios e mysas se digan e canten en la iglesia catedral de Cuenca.

Item, mando que sea fecho mi anual de pan e vyno e çera segund que es costumbre, e que lo fagan la priora e monjas del monesterio, a las quales mando porque lo fagan quatro cafiçes de trigo e mill maravedís en dyneros para que compren vyno e çera para el dicho anual, e que fagan desir una misa cantada cada día en todo el dicho año que se fisiere el dicho anual, que son tresientas e sesenta e çinco o seys misas, para las quales les mando tres mill maravedís, e que paguen ellas el capellán que dixiere la misa del anual cada día, e que sea buen clérigo e de buena vida e fama el capellán que dixiere las misas del dicho anual, e que luego comiençen a faser desir las dichas misas del dicho anual commo fuere pasado de la presente vida.

Item, mando que las dichas priora e monjas digan por mi ányma e fagan cantar un tryntanario ençerrado o revelado vulgarmente dicho, que dure treynta días fasiendo desir cada día una misa cantada, una del tryntanario e la otra misa del anual cada día cantada, en tal manera que se digan dos misas cada día cantadas en quanto durare el treyntanario, e después que se continuen las misas del anual, e mando que diga el dicho treyntanario Alfonso Sánches de Huepte, mi confesor capellán, e que demande liçençia al los dichos señores deán e cabyldo para desyr el dicho tryntanario, e mando que le den mill maravedís e dos cafiçes de trigo por su trabajo.

E ruego a las dichas monjas que ayunen por mi ányma los dichos treynta días en que durare el dicho treyntanario, e que acabados los dichos treynta días continuos que fagan e fagan desir al dicho capellán que dixiere el dicho treyntanario tres misas de la trenydad, e que non lo puedan desir dos capellanes salvo uno que diga las dichas trynta e tres misas continuas sin yntervalo alguno. E que el dicho capellán pueda estar e dormir en Sant Salvador, e de ally sallyr a desir la misa e después tornarse ally. E ruego a los que dixieren las dichas misas, asy del anual commo del treyntanario, que se confiesen cada día.

Item, mando a las monjas que ayuntaren mill maravedís para pescado e fruta e seys cafiçes de trigo, e que luego commo muriere comiençen a desir e faser desir las dichas misas, asy del treyntanario commo del anual segund dicho es, e porque más ayna mi ányma salga del purgatorio si a nuestro señor Dios ploguiere de la levar del.

Item, mando dar al dicho capellán que dixiere el dicho treyntanario çinco maravedís cada día de los dichos treynta e tres días, para que los de por su mano a pobres por amor de Dios, porque con la dicha helemosina de los dichos çinco maravedís e ayuno de las dichas monjas nuestro señor resçiba el sacrifiçio que por mi ánima fisiere el dicho capellán, e a él sea más agradesçido con las dos alas de la lymosna e del ayuno.

Item, mando que se faga otro anual por mi ányma en la dicha mi capilla, en la qual se diga cada día una misa cantada, e que la diga my capellán que fuere en aquel tiempo, e quando él non la podiere desir que busquen otro que la diga, e que sea de buena 
vida, e que cada día se ofresca un quartillo de vino e dos panes, e la çera que se tome de la que sobrare de las misas e ofiçios que se fisieren por mi ányma, e que le den por su trabajo tres mill maravedís.

Item, mando a los señores deán e cabildo de la iglesia de Cuenca mill maravedís, a los quales suplico que les plega de faser ofiçios e rogar a Dios por mi ánima. E pídoles por merçed que me remytan las pitanças mal ganadas, e qualesquier dineros e otras qualesquier cosas en que les so obligado de las restituyr por las horas mal ganadas o por otras qualesquier cosas que les deviere, porque nuestro Señor Dios les quiera perdonar. E mándoles las cosas que están escriptas en el libro pequeño de las tablas blancas, las que yo en mi vida non compliere, e las que compliere antes de mi muerte que sean contentos e que non les sean dadas.

Item, mando que los curas e frayles e clérigos desta çibdad, e capellanes e canónigos extravagantes de la dicha iglesia de Cuenca, fagan ofiçios complydos por mi ánima el día de mi enterramyento e terçero e seteno e nono e treçésimo día e en cabo del año, que son seys ofiçios, e que les den lo que es acostumbrado de pagar. E en cada ofiçio de los sobredichos se pongan trese çirios nuevos, cada çirio de una libra en cada uno en cada vegada que ofiçios se fagan, los dichos trese çirios nuevos cada uno de una lybra, e tres antorchas de seys libras cada una, e la çera que sobrare de los dichos çirios sea para el dicho tryntanario e anual que se dixiere en la dicha mi capilla.

Item, mando más a los dichos señores deán e cabildo todos mis libros que tengo en latyin, e pídoles por merçed que fagan las çinco memorias e adniversarios, el uno por los honrrados señores cardenal de Sabyna don Gil e por mys bien fechores, e el otro por mi señor don Álvaro de Ysorna, que fue arçobispo de Santiago e primeramente obispo de Cuenca, e el otro por don Pedro de Vaamonde mi señor, obispo que fue de Mondoñedo e provisor que fue deste obispado, e el otro por las ánymas de mi padre e madre, e el otro por mi ányma, segund que están escriptos en los lybros de los pytançeros e en el libro pequeño de la dicha yglesia de cubiertas blancas e agora está de peto cubierto. E que non pongan otra persona con los sobredichos el día de su adniversario, sobre lo qual les encargo las conçiençias si otro pusieren, porque cada uno aya su sacrifiçio entero e complydo. E mando a los dichos señores dies mill maravedís, segund que están escriptos en el dicho libro de cubiertas blancas, si ge los non pagare en mi vida, e que vendan de los libros míos que dexare los que non fueren menester para la librería, e que de los dyneros que valieren los dichos libros e los dichos dies mill maravedís compren una posesión en que sean sytuadas çinco memorias e adniversarios que dexo hordenadas, e esto se entienda sy yo non los compliere antes que muera. E los dichos libros nin alguno de los que yo dexo e fincaren para la dicha librería que se non puedan vender ni empeñar nyn enagenar, e sy lo fisieren que por ese mesmo fecho sean para la fábrica de la dicha yglesia, e los libros que se han de vender son el decreto e decretales, que son muy verdaderas aunque non son fermosas, e las clementynas y el sexto que fue de la iglesia y di otro por él porque era fermoso, el qual el cabildo vendió al prior de Uclés para un su sobryno, e si otros lybros tovieren que non sean menester para la librería véndanse para comprar la posesión para los dichos adniversarios. 
Item, mando para la maytinada continua las casas nuevas que yo fise en el barrio de Sant Pedro, e ruego a los canónigos extravagantes que me fagan dos memorias en cada un año, segund que ellos las fasían en quanto yo bevy, la una que fagan segundo día del adviento e la otra primer día de quaresma, en las quales memorias se repartan una parte de la meytad de lo que rendieren las dichas casas, comprando primeramente la çera que fuere menester para las dos mysas e pagando al capellán que dixere las dichas dos mysas, e la otra parte de la meytad que les dexo sea para la maytinada contynua de cada día. E porque muchos canónigos extravagantes e capellanes e otros benefiçiados procuran de venyr en cobdiçia desornada en los dichos días que se fisieren las dichas dos memorias, más por ganar los dyneros que por rogar a Dios por my ányma, segund que muchos vienen a los maytines de Santa Çeçillya a esta iglesia de Cuenca, por ende mando e hordeno que non pueda alguno ganar nin aver parte en los dichos dyneros de las dichas memorias salvo los benefiçiados e capellanes e canónigos extravagantes que por un mes antes, ynterpolado o continuo, vinieren a maytines, convyene a saber que desde Sant Iohan fasta el Aviento venga a maytines un mes el que ovyere de ganar los dyneros que se repartieren a la memoria que se fisiere el segundo día del Aviento, e desde Navydad fasta primero día de quaresma vengan un mes a maytines el que ovyere de ganar los maytines e dineros que se repartyeren en la memoria que se fisiere el primero día de quaresma, que sea ynterpollado o continuo, e mando que estas memorias que se fagan en la dicha mi capilla. E complido esto, de los maravedís que ryndieren las dichas casas mando que den e paguen a los señores deán e cabyldo de la dicha iglesia de Cuenca quatroçientos maravedís cada un año perpetuamente para que me fagan dos memorias cada un año perpetuamente, una por Sant Myguell de mayo e otra por Sant Myguell de setiembre en la dicha mi capilla. E que sy por ventura Luys de Fuente Encalada mi sobrino quesiere bevir en esta çibdad, que las dichas casas pueda thener él en su vida con condiçión que pague cada un año por ellas mill maravedís, e que destos mill maravedís se paguen los dichos quatroçientos maravedís para las dichas dos memorias, e los otros seysientos maravedís sean para la dicha maytinada segund dicho es, e después de la vida del dicho Luys mi sobrino sean e tornen las dichas casas a la dicha maytinada. E se guarde la forma susodicha en tal manera que sy por ventura caso fuere que en algund tiempo las dichas casas no ryndiesen más de los dichos quatroçientos maravedís que quiero y es mi voluntad que sean los dichos quatroçientos maravedís para los dichos señores, para que fagan e cumplan las dichas dos memorias en cada un año en la dicha mi capilla perpetuamente.

Item, mando que demanden a Iohan Sánches, cura de Villar del Forno, los maravedís que le dí para que me escriviese un breviario e los pergamynos que le dí para ello, segund se fallará en el lybro de mys cuentas. E item, mando a las monjas de Santa Marya de Contemplaçión desta çibdad un misal nuevo que yo tengo, para serviçio del altar del dicho monesterio. Item, mando la brivya que yo tengo a la iglesia de San Bartholomé de Belmonte, porque mucho tiempo ha que ge la tengo dada, segund que está escripto en una foja en prinçipio de la dicha brivya, la qual mando poner en la sacristanya de la dicha iglesia o en otro lugar, donde fuere visto mejor por los vicarios e clérigos de la dicha iglesia, con cadenas atada porque non sea levada, e los que quisieren por ella leer e estudiar lo puedan faser, e que la non pueda vender ni enagenar 
ni empeñar, e sy lo fisieren que por ese mismo fecho sea para la iglesia de Cuenca e para la librería della.

Item, mando más a la dicha iglesia de Belmonte, el raçional que fise escrivyr en papel, e el libro pobre e otro libro que se llama manipulo escolastorum, e todos los dichos tres libros sean puestos con sus cadenas çerca de la dicha brivya que yo dy a la dicha iglesia, con condiçión que non los puedan vender nyn enagenar nin sacar de la dicha iglesia los dichos quatro libros. E porque al presente la dicha iglesia de Belmonte non está acabada de faser, mando que en tanto que la dicha iglesia se fase que estén depositados los dichos quatro lybros en poder del prior de la dicha iglesia fasta que la dicha iglesia sea fecha, porque se cumpla esto que yo mando, sobre lo qual le encargo su conçiençia.

Item, mando que el breviario que fue de Pero Xuáres, canónigo que Dios aya, que lo vendan e de los dyneros que valieren compren mys testamentarios una posesión, e lo que ryndiere esta posesión fagan los señores deán e cabildo una memoria cada un año por el ányma del dicho Pero Suáres.

Item, mando para la dicha mi capilla dos breviarios míos que yo tengo, el uno de regla toledana e el otro de regla romana, de dos romanos que tengo el mejor, y estos dos brevyarios que estén fixos en la dicha mi capilla en la pared puestos en sus rexas con sus cadenas, para en que puedan resar los capellanes que syrvyeren la dicha mi capilla o otros qualesquier clérigos que quisieren porque rueguen a Dios por mi ányma.

Item, mando que cada e quando el bachiller Pero Ximénes Çomeño, cura de Montalvanejo, quisiere estudiar en qualquiera de los lybros que yo dexo que ge los den para que los tenga en su casa estando presente en Cuenca, dando seguridad que los bolverá a la dicha librería, e pido por merçed a los señores deán e cabildo que esto quieran faser porque le quyero bien, e porque es buen letrado e clérigo, e tenga cargo de rogar a Dios por mi ányma.

Item, mando todas las heredades que yo compré en Belmontejo, de cabo la Parrilla, y en Fuentes Claras y en Mohorte para mi capilla donde yo me tengo de sepultar. E más mando a la dicha mi capilla tres pares de casas que yo compré en esta çibdad, las dos pares que están juntas en la Çapatería e otras en varrio Sant Pedro, las quales dichas heredades e casas mando para mantenymyento a dos capellanes que aya en la dicha mi capilla perpetuamente, e que los dichos capellanes sean obligados de desir en la dicha mi capilla cada día una misa, cada capellán su semana. E quiero e es mi voluntad que Luys de Fuente Encalada mi sobrino sea patrón de la dicha mi capilla en su vida, e que él pueda elegyr e presentar los capellanes que él viere que son ydóneos e pertenesçientes para servyr la dicha mi capilla, non seyendo públicos concubynarios, e aquellos capellanes que el dicho mi sobrino en su vida eligiere e presentare que el prelado que al presente fuere en este obispado les provea de las dichas capellanías, e non en otra manera. E después de la vida del dicho Luys de Fuente Encalada mi sobrino, quyero e es mi voluntad que subçedan en el dicho patronadgo los venerables señores deán e cabyldo de la iglesia de Cuenca mis hermanos, para que ellos unányme e de una voluntad puedan elegyr e presentar los capellanes que ellos vieren ser ydóneos e pertenesçientes para servyr las dichas capellanyas, non seyendo concubynarios segund dicho es, e aquellos capellanes que ellos eligieren, nombraren e 
presentaren el dicho prelado que a la sasón fuere lo pueda proveer dellas e non en otra manera, y esto se tenga e guarde perpetuamente. E mando e es mi voluntad que los capellanes que asy fueren nombrados e proveydos de las dichas capellanyas que ellos mesmos por sy personalmente sirvan las dichas capellanyas e digan las dichas misas, e non por otra ynterposita persona, e los capellanes que el contrario fisieren e non fueren honestos en su bevyr que por el mesmo fecho pyerdan las dichas capellanías.

Item, digo e declaro que Pedro de Sanabrya mi criado e su muger, vesinos de Millana, después de su vida dellos tienen mandados todos sus byenes que ellos tienen e poseen a la dicha mi capilla de San Miguell, mando e es mi voluntad que los dichos Pedro de Sanabria e la dicha su muger que agora tiene se puedan enterrar en la dicha mi capilla, e que después de su vida dellos, quedando los dichos bienes a la dicha mi capilla y a los capellanes della que al presente fueren, que los dichos capellanes sean obligados de les desir cada semana dos misas por sus ánymas perpetuamente, e mando que de mis bienes den e paguen al dicho Pedro de Sanabria, para ayuda a sostener los dichos bienes, tres mill maravedís.

Item, mando que de mis byenes compren una casa para dar en yguala por la casa que está ençima de la dicha mi capilla, e que la dicha casa que está ençima de la dicha mi capilla que la derriben, en tal manera que entre ella e la dicha mi capilla quede calle sufiçiente en tal manera que non aya ninguna subjebçión sobre la dicha mi capilla, e en lo que quedare por derribar de la dicha casa sea para que moren los dichos capellanes que syrvieren la dicha mi capilla, e mando que sea enlosado de buena piedra en derredor de la dicha mi capilla de partes de fuera, por manera que non pueda entrar ninguna humidad a ella.

Item, mando que paguen al liçençiado físico un cafis de trigo de la mayor deste año, porque ha tenido cargo de mi casa. Item, mando mi hopala prieta, la nueva, a Alfonso Sánches el Pardo, porque ruegue a Dios por mi ányma. Item, más a los frayles de Sant Françisco mill maravedís porque rueguen a Dios por mi ányma. Item, mando que de la renta de la heredad de Belmontejo deste año que se faga de nuevo una casa e se acaben las otras, e sy más fuere menester que lo paguen de mis byenes. Item, mando a Iohan de Ocaña mi criado, por serviçios que me fiso, veynte mill maravedís e más todos los frutos deste año de la mi prestamera de Tribaldos desta dióçesis. Item, mando a Alfonso Terçeado çinco mill maravedís. Item, mando a Alfonso de Myllana ocho mill maravedís. Item, mando a Gonçalo de Myera quinse mill maravedís. Item, mando a [roto] veynte mill maravedís y el machón de silla que tiene. Item, mando a Garçía quinse mill maravedís. Item, mando a Pedro quinse mill maravedís. Item, mando a Françisco dos mill maravedís. Item, mando [a] Ferrandico çinco mill maravedís. Item, mando a Diaguito çinco mill maravedís. Item, mando a las amas que están en casa, a cada una mill maravedís. Item, mando que los niños que están por criar que los crien a my costa, e que después que los den a quien mis testamentarios quisieren. Item, mando a Ferrando de Sanabria seys mill maravedís. Item, mando a Bartholomé de León çinco mill maravedís. Item, mando a Palomares quatro mill maravedís. Item, mando a Lope de Alcáçar quatro mill maravedís. Item, mando a Luys, el que mora en Alfaro, dies mill maravedís. Item, mando a Valdemeca quatro mill maravedís. Item, mando a Iohan Carrillo dos mill maravedís. E complido e acabado esto que yo mando por este mi testamento, dexo por mis testamentarios 
a Luys de Fuente Encalada mi sobryno, e al prior de Belmonte e a Diego de Valera, canónigos, e a Alfonso Sánches de Huepte, capellán, a los quales todos juntos o a la mayor parte dellos do poder complido para executar esto que yo mando, segund y en la forma e manera que testamentarios lo pueden y deven aver. E esto complydo, de lo que quedare e fyncare dexo por mi heredero universal al dicho Luys de Fuente Encalada mi sobrino. E revoco qualesquier testamentos que antes deste aya fecho, e quyero que este vala e sea fyrme para agora e para en todo tiempo, e sy non valiere por testamento que vala por cobdicillio, e sy non valiere por cobdicillyo que vala por mi postrimera e última voluntad. E por esta carta do todo poder complido a los dichos mis testamentarios o a la mayor parte dellos para que de lo mejor parado de mi fasienda cumplan e executen todo esto que yo mando en este dicho mi testamento y cada una cosa e parte dello, segund que ellos fisieren por mi ányma asy depare Dios quien faga por las suyas en el tiempo que lo ovieren menester, sobre lo qual les encargo sus conçiençias. Que fue fecho e otorgado este testamento en la noble çibdad de Cuenca, en siete días del mes de agosto, año de la nativydad del nuestro salvador Ihesuchristo de mill e quatroçientos e setenta e seys años. Testigos que fueron presentes para esto espeçialmente rogados e llamados los honrrados Pedro de Párraga, canónigo en la iglesia de Cuenca, e el liçençiado físico, e Françisco Martínes de Baeça, raçionero, e fray Guillén, guardián de Sant Françisco, e fray Pedro de Peñalver, frayles de la horden de San Françisco, e Iohan Sánches Cachero e Diego de Aranda, vesinos de Cuenca, e Iohan de Ocaña, qriados del dicho señor chantre, e yo Miguell Sánches Çomeño, notario apostólico.

E yo Miguel Sánches Çomeño, de la diócesis de Cuenca notario público por la actoridad apostólica a mí dada e otorgada, fuy presente a todo lo susodicho e a cada una cosa e parte dello en uno con los dichos testigos, e ví e oy al venerable e çircunspecto varón don Nuño Álvares de Fuente Encalada, doctor en Decretos e chantre de la eglesia de Cuenca, que lo otorgó segund e por la vía e forma que en él se contiene estando doliente en una cama. E segund que ante my pasó e por el dicho señor chantre fue otorgado, e ocupado de otros negoçios, por otros fielmente lo fis escrivir este público instrumento de testamento en esta pública forma, el qual va escripto en estas seys fojas de pliego entero, e las dos fojas están fechas una foja e pegadas e escritas de la una parte por causa que el paper era delgado, porque se pasava por causa de las letras prinçipales, e las otras quatro fojas van escritas de amas partes, e van firmadas de la una parte de mi nombre e de la otra una rúbrica del con esta en que va este myo sygno e suscreçión, e de pedimiento e otorgamiento del dicho señor chantre, en fe e testimonio de verdad, con este myo sygno acostumbrado lo sygné rogado e requerido. Va escrito entre renglones onde dis comyençen, que non noçeat.

E después de lo sussodicho, en la noble çibdad de Cuenca, a nueve días del dicho mes de agosto, año de la natividad del nuestro salvador Ihesuchristo de mill e quatroçientos e setenta e seys años, en presençia de mí el dicho Miguell Sánches Çomeño, notario, e de los testigos yuso escriptos, el dicho señor don Nuño Álvares de Fuente Encalada, chantre de la dicha iglesia de Cuenca, estando dolyente en una cama propuso e dixo que, avyendo por rato e grato, firme, estable e valedero todo lo contenido en el dicho su testamento e cada una cosa e parte dello, dixo que por quanto Alfonso Estévanes, habitante en esta çibdad, defunto que Dios aya, avya mandado 
en su testamento que fuesen dados a una persona que estava en Santiago de Galisia mill maravedís, los quales el dicho señor chantre avya embiado con Alfonso, portero, a Santiago a los dar e pagar a la dicha persona, e el qual dicho Alfonso portero avya dicho que ge los avyan robado en el camyno, por manera que non se avyan dado, por tanto que agora mandava que de sus bienes que sean pagados los dichos mill maravedís, e que sean embiados a buen recabdo a Santiago e los den e paguen a la dicha persona contenyda en el testamento del dicho Alfonso Estévanes.

Item, dixo e mandó que fuese dado a las dichas monjas del dicho monesterio de Santa María de la Contemplaçión dos ollas, una de cobre e otra de arambre, e dos cántaros de arambre para serviçio del dicho monesterio, e que los otros dos cántaros de arambre suyos que los pongan en la dicha su capilla de Sant Miguell, para thener aseyte para las lámparas de la dicha capilla, e que sean puestos en el logar que él tenya deputado para ello.

Item, dixo e mandó que fuesen pagados a los frayles de la Merçed desta çibdad mill maravedís para ayuda e reparo del monesterio de la Fuent Santa. Item, mandó que una çamarra nueva que él tenya que fuese dada a Fray Ambrosio, frayle de la horden de San Gerónymo en la Sisla de Toledo. Item, dixo e mandó que otra çamarra que agora se fasía que la acaben e fagan acabar e la paguen de sus dyneros e la den los dichos sus testamentarios graçiosa al prior general de Sant Bartolomé de Lupyana. Item, dixo e mandó que de sus byenes sea dado a la madre de Montenegro, su criado, e a la madre de Theresa de Salynas, sendas sayas e sendos mantos e sendos tavardos de paño pardillo común de Cuenca, en lymosna por serviçio de Dios. Item, el dicho señor chantre mandó e declaró e que le plasía que Diego de Valera, canónigo que presente estava, que pueda desir misa en la dicha su capilla todo el tiempo que él quisiere e por bien tovyere, e que los capellanes de la dicha capilla ni otra persona alguna non ge lo puedan ympedyr, perturbar nyn contradesir. E demás y allende desto que él quería e le plasía que el dicho Diego de Valera se pueda sepultar en la dicha su capilla, graçiosamente syn dinero alguno, por grande amor e afectión que con él tenya, e por muchos trabajos que con él avía pasado en esta su dolençia, e asy mismo dixo e mandó que todos sus criados se puedan sepultar en la dicha su capilla, graçiosamente syn dinero alguno, en el logar que él dexaba deputado. E que estas mandas e cada una dellas dixo que mandava e declarava por su cobdiçillyo, e dixo a my el dicho notario que asy ge lo diese por testimonio, lo qual mandava que valyese e fuese firme e valedero asy commo el dicho su testamento original. Testigos que fueron presentes para esto espeçialmente rogados e llamados maestre Martín, çirujano, e Alfonso Terçeado e Iohan de Ocaña, sus criados, e yo el dicho Miguell Sánches Çomeño, notario appostólico.

E después desto, otro día siguyente dies días del dicho mes de agosto, año susodicho de setenta e seys, en presençia de my el dicho notario e de los testigos yuso escriptos, el dicho señor chantre, avyendo por fyrme e rato e grato todo lo susodicho e cada una cosa e parte dello, dixo que mandava e mandó que fuesen embiados a su costa del a Ynés Álvares, su hermana, e a Pero Álvares, su hermano, e a Diego Álvares e a Iohan Álvares, sus sobrynos, sendos niños destos que él avya fecho criar para que los críhen e fagan bien por serviçio de Dios e por amor suyo. E que al dicho Diego de Valera que le den una niña para que la críhe e la case, e a Alfonso Terçeado su 
criado que le den a Calisto y a Tecla para que los críe e los case por serviçio de Dios e por amor suyo, el qual dicho Alfonso Terçeado dixo que era contento e le plasía de lo faser. E más dixo e mandó que sy alguno de sus criados quisiese a alguno de los dichos niños para criallo que ge lo diesen. Testigos que fueron presentes para esto llamados e rogados los dichos señores prior de Belmonte e Diego de Valera, canónigos, e Alfonso Terçeado e Alfonso de Millana, sus criados. E desto en commo pasó pydió a my el dicho notario que asy lo diese por testimonio.

E yo Miguell Sánches Çomeño, de la diócesis de Cuenca notario público por la actoridad apostólica a mí dada y otorgada, fuy presente a todo lo susodicho y cada una cosa y parte dello en uno con los dichos dichos [sic], e ví e oy al dicho señor chantre que lo otorgó, e segund que ante my pasó e por el dicho señor chantre fue otorgado por otro fielmente lo fis escrivir este público instrumento de codeçillos en esta pública forma, los quales van escritos en estas dos fojas de pliego entero con estas en que va mi sygno e suscreçión, e de pedimyento e otorgamyento del dicho señor chantre en fe e testimonio de verdad con este myo sygno acostumbrado lo sygné rogado e requerido. 